\title{
Ecology and molecular characterization of Neozygites tanajoae (Entomophthorales: Neozygitaceae) a fungal pathogen of the cassava green mite
}

\author{
Dissertation \\ to obtain the Ph.D. degree \\ in the International Ph.D. Program for Agricultural Sciences in Goettingen (IPAG) \\ at the Faculty of Agricultural Sciences, \\ Georg-August-University Göttingen, Germany
}

by

Bonaventure Vidjannagni AGBOTON

Born in Klouékanmè, Benin

Göttingen, December 2008 
1. Examiner:

Prof. Dr. Andreas von Tiedemann (Supervisor)

Director of the Department of Crop Sciences,

Division of Plant Pathology and Crop Protection,

University of Göttingen, Germany

2. Examiner:

Prof. Dr. Stefan Vidal (Co-supervisor)

Department of Crop Sciences,

Division of Agricultural Entomology,

University of Göttingen, Germany

\section{Examiner:}

Prof. Dr. Petr Karlovsky

Department of Crop Sciences,

Division of Molecular Phytopathology and Mycotoxin Research

University of Göttingen, Germany

Place and date of defense: Göttingen, $14^{\text {th }}$ January 2009 


\section{Tro}

\section{all my Family}

Maguerite AGOSSAVI my mother

My dear late Rosemonde ABIKo and our son Eden D. Junior AGBOTON

$$
\text { "Glory to God" }
$$


Contents......................................................................4

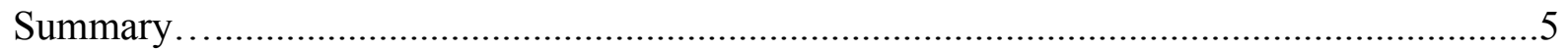

Introduction..................................................................

Objectives................................................................13

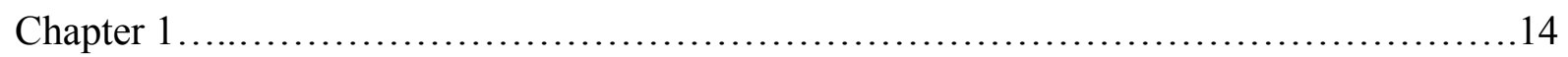

Molecular detection and differentiation of Brazilian and African isolates of the entomopathogen Neozygites tanajoae (Entomophthorales: Neozygitaceae) with PCR using specific primers.

Bonaventure V. Agboton, Italo Delalibera Jr, Rachid Hanna and Andreas von Tiedemann

Chapter 2

Molecular detection of establishment and dispersal of Brazilian isolates of Neozygites tanajoae in Benin (West Africa) a fungus pathogenic to cassava green mite.

Bonaventure V. Agboton, Rachid Hanna and Andreas von Tiedemann

Chapter 3 ....

Pathogenicity and host specificity of Brazilian and African isolates of the acaropathogenic fungus Neozygites tanajoae to mite species associated with cassava.

Bonaventure V. Agboton, Rachid Hanna, Fabien C. C. Hountondji and Andreas Von Tiedemann

Chapter 4

Interactions between the entomopathogenic fungus Neozygites tanajoae and the predatory mite Typhlodromalus aripo in the biological control of cassava green mite (Mononychellus tanajoa).

Bonaventure V. Agboton, Rachid Hanna, Alexis Onzo, Stefan Vidal and Andreas Von Tiedemann

General Discussion.

List of publications 88

Acknowledgments. .90

Curriculum vitae. 


\section{Summary}

For the biological control of the cassava green mite (Mononychellus tanajoa, Bondar), Brazilian strains of the entomopathogen Neozygites tanajoae were recently introduced into Africa to improve the control achieved by predatory mites. In order to monitor the establishment of the Brazilian strains two PCR primer pairs, NEOSSU_F / NEOSSU_R and 8DDC_F / 8DDC_R were tested on $N$. tanajoae strains collected from several locations in Brazil and from three countries in Africa, Benin, Ghana and Tanzania. The first primer pair enabled the species-specific detection of $N$. tanajoae, while the second differentiated the Brazilian isolates from those of other geographical origin. The results confirmed that the two primer pairs tested are suitable for the detection of $N$. tanajoae and the differential identification of Brazilian and African strains. PCR can therefore be used to monitor the establishment and spread of the Brazilian strains in Benin and in other African countries where they have been introduced recently in order to improve cassava green mite (CGM) control.

In this work the establishment and spread of Brazilian strains of $N$. tanajoae were followed in a countrywide survey in Benin in which a total of 141 cassava fields were inspected. Samples of M. tanajoa suspected of being infected by $N$. tanajoae were found in 60 fields distributed between the coastal Southern Forest Mosaic (SFM) and the Northern Guinea Savannah (NGS) zones. PCR analysis of DNA samples extracted from samples from these fields revealed that $N$. tanajoae is well distributed in Benin and that Brazilian strains were effectively established and have spread throughout the country. However, the highest rates of infection due to Brazilian strains were observed in the sub-humid and humid savannah zones of the country. Identification of $N$. tanajoae strains using molecular tools, however, is very costly. Hence, development of alternative techniques is desirable. Therefore, the difference in biocontrol performance and in host ranges was compared to discriminate between African and Brazilian strains of $N$. tanajoae. The results suggest that the biocontrol potential and the host ranges bioassays are suitable for evaluating the infectiveness of $N$. tanajoae on cassava green mite. However, those methods were not suitable for differentiating among different origins of strains of the entomopathogenic fungus.

The establishment of $N$. tanajoae in Benin after its introduction for the control of cassava green mite resulted in co-occurrence with the predatory mite Typhlodromalus aripo in cassava fields. However, little is known on the interaction of the two antagonists and on the biological control potential of $M$. tanajoa. In a series of greenhouse experiments, effects of single and 
combined releases of $N$. tanajoae and T. aripo on their respective population dynamics and on the suppression of $M$. tanajoa populations were evaluated. In order to complement the greenhouse experiments, laboratory experiments were conducted to evaluate the feeding, oviposition and longevity of $T$. aripo fed with healthy or $N$. tanajoae-infected M. tanajoa. The results showed that simultaneous release of T. aripo and $N$. tanajoae in the same cassava field may be detrimental to the biological control of the cassava green mite. It is therefore preferable to release in each area only the antagonist species known to be well adapted to the prevailing environmental conditions.

In conclusion, this thesis shows that molecular techniques are the most suitable methods to detect infection of CGM by $N$. tanajoae and to differentiate among strains. Molecular techniques are also useful for monitoring the establishment and dispersal of introduced N. tanajoae species in the field. Furthermore, this study increased our knowledge on the performance and host ranges of the African and Brazilian strains of N. tanajoae. It also improves our understanding of the interaction between $N$. tanajoae and the most effective predatory mite $T$. aripo as both biocontrol agents are sharing the same habitats.

Future research should focus on in vitro production and cryopreservation of African strains of $N$. tanajoae in order to develop specific primers for detecting African isolates. Furthermore, studies of the genetic diversity of $N$. tanajoae populations in the cassava fields using molecular techniques could strongly improve our understanding of the interaction between exotic and native fungi in the cassava ecosystem. Further investigations are required on the interaction between the predatory mite T.aripo and the pathogen $N$. tanajoae at a larger spatial scale and under natural conditions, and on factors affecting the loss in biocontrol potential of exotic species of $N$. tanajoae when introduced in their new environment. 


\section{Introduction}

Cassava (Manihot esculenta Crantz, Euphorbiaceae) is an important perennial crop that serves as an important source of carbohydrates to over 200 million people in Africa (Herren and Bennett, 1984). It was introduced into Africa from South America by Portuguese traders in the late sixteenth century (Jones, 1959; Cock, 1985). Until the early 1970s, the crop was relatively free of serious pests at which time the cassava green mite (CGM), Mononychellus tanajoa (Bondar) (Acari: Tetranychidae), a native to Southern America was accidentally introduced into sub-Saharan Africa, causing significant reduction in crop yields (30-80\%) and threatening food security throughout much of the African cassava belt (Lyon 1973; Herren and Bennett 1984; Yaninek and Herren 1988). Biological control of the cassava green mite has been favoured over chemical control given the fact that with biocontrol the farmer does not incur any additional production costs, and that damage to non-target organisms and environmental pollution possibly associated with chemical control are prevented. In the early attempts of biological control against CGM in Africa exotic natural enemies were used, particularly various phytoseiids, introduced from South America. Unfortunately, none of the predatory mites species consistently established in the arid, semi-arid, and mid-altitude areas of Africa. And where the establishment was successful, the reductions of M. tanajoa populations by the introduced phytoseiids were estimated no higher than 50\% (Yaninel and Hanna, 2003).

On the other hand, numerous species of arthropod-pathogenic fungi are known to cause naturally-occurring epizootics that decimate host population in the native home of cassava green mite. The entomopathogenic fungus, Neozygites sp. was reported to be causing epizootics among populations of M. tanajoa in South America (Agudelo-Silva, 1986; Delalibera et al., 1992). Therefore, N. tanajoae Delalibera Jr., Humber \& Hajek (Zygomycetes: Entomophthorales) has become an important natural regulator of populations of M. tanajoa in northeastern Brazil (Delalibera Jr. et al., 1992, 2000, 2002). Hence, introduction of the Brazilian isolates of the fungus $N$. tanajoae into Africa was envisaged to complement the phytoseiids' activities. The pathogenic fungus $N$. tanajoae, one of the most efficient natural enemies of CGM in Brazil (Delalibera 2002), was experimentally introduced in Benin (West Africa) in 1998/1999 for the control of cassava green mite. N. tanajoae is highly specific to CGM as it is not known to infect another host (Delalibera et al. 2004). This fungus was initially referred to as Neozygites sp. (Delalibera et al. 1992) and later as the broad mite fungus Neozygites floridana (Oduor et al. 1995, Keller 1997, Elliot et al. 2000). 
N. tanajoae isolates from Brazil are morphologically similar to those found in Africa and other countries of South America (Delalibera et al., 2004). Consequently it is difficult to conduct post-release monitoring of introduced species in Africa. Although post-release monitoring studies conducted in experimental fields in Benin in 2000 revealed higher infection rates in plots where the Brazilian isolates had been released compared with the indigenous species (Hountondji et al. 2002), there is only vague evidence of establishment and better performance of the Brazilian isolates, as no reliable techniques have been available until recently to differentiate between African and Brazilian strains of $N$. tanajoae. In the search for more suitable means to separate different strains or species of the fungus, molecular tools were thought to help overcoming the weaknesses of the classical (epizootiological and phenotypical) diagnostic methods (e.g. Lee et al. 1993; Bonants et al. 1997; Brasier et al. 1999; Judelson and Tooley, 2000). In fact, molecular probes were developed that overcome the constraints of morphology-based assessments (Ersek et al. 2003; De Merlier et al. 2005). Polymerase chain reaction (PCR)-based techniques have, since, become widely used for the detection of plant pathogens (Gachon et al. 2004; Lievens et al. 2005; McCartney et al. 2003) as well as herbivore pathogens (Tigano et al. 2006; Baek et al. 1998; Peres et al. 2006). Attempts were also made to use molecular techniques for the differentiation of $N$. tanajoae isolates from Brazil and Africa (Delalibera et al., 2004). Among the available molecular techniques, the PCR technique based on amplification of the ITS region of the ribosomal DNA (18S rDNA) was first tried, however, without success. Alternatively, Amplified Fragment Length Polymorphism (AFLP) technique, that integrates larger parts of the genome and that is able to detect even minor differences, was tried (Delalibera et al. 2002). The possibility of culturing $N$. tanajoae in vitro has greatly facilitated genetic studies aiming at developing molecular probes for strain detection (Delalibera Jr. et al., 2003). In spite of that, appropriate tools for an effective monitoring of $N$. tanajoae establishment were lacking. To correct this weakness, two specific pairs of oligonucleotide primers were designed in 2003 for PCR detection and determination of geographic strains of $N$. tanajoae from Brazil and Africa. The development of the probes was based on Brazilian strains and on only one African strain from Benin (West Africa). A need to test this probe against several indigenous strains from Africa was necessary to prove its suitability in post-release studies of $N$. tanajoae. In this thesis, after validating the probe, we tested the performance of molecular techniques to monitor the establishment and dispersal of Brazilian isolates of $N$. tanajoae that had been released in cassava fields in Benin to control M. tanajoa. This is the first major study on the occurrence, establishment and distribution of Brazilian isolates of $N$. tanajoae in the main 
cassava production areas in Benin. Information presented here provide is a key element for an appropriate post-release monitoring of $N$. tanajoae and will allow to improve follow-up strategies for the use of pathogenic fungi in any microbiological control program.

Although the molecular technique was reliable for differentiating among $N$. tanajoae strains, the need for alternative methods still exists due to the high cost of molecular assays. Among the possible methods, attention was turned to the biocontrol potential and host ranges of Brazilian and African isolates of $N$. tanajoae. While many studies have concluded on the specificity of the Brazilian strain of $N$. tanajoae to CGM (Moraes and Delalibera, 1992; Hountondji et al., 2002; Delalibera et al., 2004), little is known about differences in the performance of the African and Brazilian strains of $N$. tanajoae on CGM. It is also not known whether the host range of the African strain of $N$. tanajoae in Africa differs from that of Brazilian strains. Therefore, differences in biocontrol performance or host ranges were assessed on cassava plants in Africa and evaluated for their suitability to discriminate between indigenous and exotic strains of $N$. tanajoae. Furthermore, besides entomopathogens, a natural population of arthropod enemies exists in the cassava fields where CGM occurs. After the establishment and spread of $N$. tanajoae in Benin, it has been found that the predatory mite $T$. aripo and the fungus $N$. tanajoae are sharing the same cassava agroecosystems. However, no data existed about the outcome of the interactions between the fungus and the predatory mites, especially with regard to the impact on their own population dynamics and on the suppression of $M$. tanajoa populations. Therefore, there is an urgent need to determine the relative contribution of each natural enemy species to the biological control of $M$. tanajoa on a short and long term and how far both antagonists could be used in an integrated pest management system.

\section{Outline of the thesis}

In the first part of the present study (Chapter 1), a series of molecular studies was conducted to test a molecular probe developed in 2003 by Delalibera for detection of $N$. tanajoae. Two specific oligonucleotide primer pairs were tested on DNA extracted from isolates collected from several locations in Brazil and on several indigenous strains from Benin, Ghana, and Tanzania in order to determine their suitability in the detection and differentiation of $N$. tanajoae.

In Chapter 2 the effective establishment of Brazilian isolates of $N$. tanajoae in Benin was monitored by using previously validated specific primer pairs. To understand how the dispersal of the Brazilian isolates released in Benin affected the infection rate of the fungus in 
cassava fields, a country-wide survey was conducted and samples for molecular investigation were collected and analysed.

In the search for alternative methods to separate exotic from indigenous strains of $N$. tanajoae, (Chapter 3), the performance of two Brazilian isolates was compared to two African strains, at individual (leaf disc experiment) and at population level (whole plant experiment). In addition, the host ranges within the main mite species commonly found on cassava plants in Africa were tested.

In greenhouse and laboratory experiments (Chapter 4), attempts were made: (1) to determine the impact of interactions between $T$. aripo and $N$. tanajoae on the population densities of $M$. tanajoa, and (2) to explain how feeding on fungus-infected prey could affect the population dynamics of the predatory mites and, consequently, the biological control of M. tanajoa. In addition, in order to understand how the predatory mite and the fungus affect each other, laboratory experiments were conducted to evaluate the feeding, oviposition and longevity of $T$. aripo fed on healthy or on $N$. tanajoae-infected $M$. tanajoa.

\section{References}

Agudelo Silva, P. 1986. A species of Triplosporium (Zygomycetes: Entomophthorales) infecting Mononychellus progressivus (Acari: Tetranychidae) in Venezuela. Florida Entomologist 67: 444-446.

Baek Seung-Cheol, M.D, Chae Hee-Jae, M.D, Dong Houh M.D, Byun Dae-Gyoo, M.D, and Cho Baik-Kee, M.D. 1998. Detection and differentiation of causative fungi of onychomycosis using PCR amplification and restriction enzyme analysis. International Journal of Dermatology 37: 682-686.

Bonants P, Hagenaar-de Weerdt M, van Gent-Pelzer M, Lacourt I, Cooke D, Duncan J. 1997. Detection and identification of Phytophthora fragariae Hickman by the polymerase chain reaction. European Journal of Plant Pathology 103: 345-355.

Brasier CM, Cooke DEL, Duncan JM. 1999. Origin of a new Phytophtora pathogen through interspecific hybridization. Proceedings of the National Academy of Sciences of the USA 96: 5878-5883.

Cock, J.H., 1985. Cassava, New Potential for a Neglected Crop. Westview press, Boulder, Co, USA, $191 \mathrm{pp}$.

Delalibera JrI, Sosa Gomez DR, de-Moraes GJ, Alentar JA de, Farias Araujo W. 1992. Infection of Mononychellus tanajoa (Acari: Tetranychidae) by the fungus Neozygites sp. (Entomophthorales) in Northeastern Brazil. Florida Entomologist 75: 145-147. 
Delalibera Jr. I, de Moraes, G.J, Lapointe, S.L, da Silva, C.A.D, Tamai, M.A. 2000. Temporal variability and progression of Neozygites sp. (Zygomycetes: Entomophthorales) in populations of Mononychellus tanajoa (Bondar) (Acari: Tetranychidae). Anais da Sociedade Entomológica do Brasil 29: 523-535.

Delalibera JrI. 2002. Investigations towards implementation of Neozygites tanajoae sp. Nov. as a classical biological control agent against the cassava green mite in Africa. PhD. Thesis, Cornell University, Ithaca, New York, $141 \mathrm{pp}$.

Delalibera JrI, Hajek AE, Humber RA. 2003. Use of cell culture media for cultivation of the mite pathogenic fungi Neozygites tanajoae and Neozygites floridana. Journal of Invertebrate Pathology 84: 119-127.

Delalibera JrI, Hajek AE, Humber RA. 2004. Neozygites tanajoae sp. Nov, a pathogen of the cassava green mite. Mycologia 96: 1002-1009.

De Merlier D, Chandelier A, Debruxelles N. 2005. Characterization of alder Phytophthora isolates from Wallonia and development of SCAR primers for their specific detection. Journal of Phytopathology 153: 99-107.

Elliot SL, de-Moraes GJ, Delalibera JrI, da-Silva CAD, Tamai MA, Mumford JD. 2000. Potential of the mite-pathogenic fungus Neozygites floridana (Entomophthorales: Neozygitaceae) for control of the cassava green mite Mononychellus tanajoa (Acari: Tetranychidae). Bulletin of Entomological Research 90:191-200.

Ersek T, Bakonyi J, Nagy, ZA. 2003. PCR-based marker for identification of interspecific Phytophthora hybrids attacking alder trees. In: Kövics Gy (ed), From Ideas to Implementation: Challenge and practice of Plant Protection in the Beginning of the $21^{\text {st }}$ Century. Proceedings $3^{\text {rd }}$ Internatl. Plant Protection Symposium. Debrecen, Hungary, Debrecen University, 2003, pp. 85-86.

Gachon C, Mingam A, Charrier B. 2004. Real-time PCR: What relevance to plant studies? Journal of Experimental Botany 55:1445-1454.

Herren HR, Bennett FD. 1984. Cassava pest, their spread and control. In: Advancing agricultural production in Africa, Arusha, Tanzania. Common Agricultural Bureau, Slough, UK.

Hountondji FCC, Lomer CJ, Hanna R, Cherry AJ, Dara SK. 2002. Field evaluation of Brazilian isolates of Neozygites floridana (Entomophthorales: Neozygitaceae) for the microbial control of cassava green mite in Benin, West Africa. Biocontrol Science and Technology 12 (3), 361370.

Hountondji FCC, Yaninek JS, de-Moraes GJ, Oduor GI. 2002. Host specificity of the cassava green mite pathogen Neozygites floridana. BioControl 47: 61-66. 
Jones, W.O. 1959. Manioc in Africa. Stanford University Press, Stanford, California, 315 pp. Judelson HS, Tooley PW. 2000. Enhanced polymerase chain reaction methods for detecting and quantifying Phytophthora infestans in plants. Phytopathology 90: 1112-1119.

Keller S. 1997. The genus Neozygites (Zygomycetes, Entomophthorales) with special reference to species found in tropical regions. Sydowia 49: 118-146.

Lee SB, White TJ, Taylor JW. 1993. Detection of Phytophthora species by oligonucleotide hybridization to amplified ribosomal DNA spacers. Phytopathology 83:177-181.

Lievens B, Thomma BPHJ. 2005. Recent developments in pathogen detection arrays: Implications for fungal plant pathogens and use in practice. Phytopathology 95: 1374-1380.

Lyon WF. 1973. A plant-feeding mite Mononychellus tanajoa Bondar (Acarina: Tetranychidae) new to the African continent threatens cassava (Manihot esculenta Crantz) in Uganda, East Africa. Pest. Artic. And News Summ. 19: 36-37

McCartney HA, Foster SJ, Fraaije BA, Ward E. 2003. Molecular diagnostics for fungal plant pathogens. Pest Management Science 59: 129-142

Moraes GJ, Delalibera IJr. 1992. Specificity of a strain of Neozygites sp. (Zygomycetes: Entomophthorales) to Mononychellus tanajoa (Acari: Tetranychidae). Experimental and Applied Acarology 14: 89-94

Oduor GI, Yaninek JS, van der Geest LPS, de-Moraes GJ. 1995. Survival of Neozygites cf. floridana (Zygomycetes: Entomophthorales) in mummified cassava green mites and the viability of its primary conidia. Experimental \& Applied Acarology 19:479-488.

Peres NA, Harakava R, Carroll GC, Adaskaveg JE, Timmer LW. 2006. Comparison of Molecular Procedures for Detection and Identification of Guignardia citricarpa and G. mangiferae. Plant Disease 91: 525-531.

Tigano MS, Adams B, Maimala S, Boucias D. 2006. Genetic diversity of Hirsutella thompsonii isolates from Thailan AFLP analysis and partial $\beta$-tubulin gene sequences. Genetics and Molecular Biology vol 29 no 4 Sào Paulo.

Yaninek JS, Herren HR. 1988. Introduction and spread of the cassava green mite, Mononychellus tanajoa (Bondar) (Acari: Tetranychidae), an exotic pest in Africa and the search for appropriate control methods: a review. Bulletin of Entomological Research 78: 1-13.

Yaninek, J.S. and Hanna, R. 2003. Cassava green mite in Africa: a unique example of successful classical biological control of a mite pest on a continental scale. In: P. Neuenschwander, C. Borgemeister and L. Langewald (eds.) Biological control in IPM systems in Africa. CABI Publishing, Wallingford, UK, pp. 61-75. 
Objectives

This thesis reports on post-release studies of Neozygites tanajoae, a pathogenic fungus used in classical microbial biocontrol of the cassava green mite (Mononychellus tanajoa). The study mainly addresses the molecular characterization and ecological aspects of $N$. tanajoae. Specific aspects addressed are:

1. Suitability of two specific oligonucleotide primer pairs using polymerase chain reaction for detecting and differentiating $N$. tanajoae strains collected from several locations in Brazil and in cassava fields in Africa (Chapter 1),

2. the use of molecular techniques to monitor the establishment and spread of Brazilian strains of $N$. tanajoae that were released in cassava fields in Benin against M. tanajoa (Chapter 2),

3. the possibility of using differences in performance or host ranges to discriminate between indigenous and exotic isolates of $N$. tanajoae (Chapter 3) and

4. the impact of the co-occurrence in same cassava agroecosystem of the pathogen $(N$. tanajoae) and a predatory mite (Typhlodromalus aripo) on biological control of $M$. tanajoa in an integrated pest management system (Chapter 4). 


\author{
Molecular detection and differentiation of Brazilian and African isolates of the \\ entomopathogen Neozygites tanajoae (Entomophthorales: Neozygitaceae) with PCR \\ using specific primers. \\ Bonaventure V. Agboton ${ }^{凶 1.3}$, Italo Delalibera Junior ${ }^{2}$, Rachid Hanna ${ }^{3}$, Andreas von Tiedemann ${ }^{1}$ \\ ${ }^{1}$ University of Göttingen, Department of Crop Sciences, Division of Plant Pathology and Plant Protection. \\ Grisebachstr. 6 D- 37077 Göttingen, Germany \\ ${ }^{2}$ Unisersity of Sao Paolo, Departamento de Entomologia, Fitopatologia e Zoologia Agrícola da ESALQ-USP, \\ Piracicaba-SP 13418-900 Brazil \\ ${ }^{3}$ International Institute of Tropical Agriculture, 08 BP 0932, Cotonou, Republic of Benin
}

\title{
Biocontrol Sciences and Technology 19 (1), 2009, 67-79
}

Corresponding author: Bonaventure V. Agboton; email: bogboton@yahoo.fr

\begin{abstract}
Neozygites tanajoae is an entomopathogenic fungus which has been used for biocontrol of the cassava green mite (Mononychellus tanajoa, CGM) in Africa. Establishment and dispersal of Brazilian isolates which have been introduced into some African countries in recent years to improve CGM control was followed with specific PCR assays. Two primer pairs, NEOSSU_F / NEOSSU_R and 8DDC_F / 8DDC_R, were used to differentiate isolates collected from several locations in Brazil and from three countries in Africa, Benin, Ghana and Tanzania. The first primer pair enabled the species-specific detection of Neozygites tanajoae, while the second differentiated the Brazilian isolates from those of other geographical origin. PCR assays were designed for detection of fungal DNA in the matrix of dead infested mites since $N$. tanajoae is difficult to isolate and culture on selective artificial media. Our results show that all isolates (Brazilian and African) that sporulated on mummified mites were amplified with the first primer pair confirming their Neozygites tanajoae identity. The second pair amplified DNA from all the Brazilian isolates, but did not amplify any DNA samples from the African isolates. None of the two primers showed amplification neither from any of the non-sporulating mite extracts nor from the dead uninfected mites used as negative controls. We confirmed that the two primer pairs tested are suitable for the detection and differential identification of $\mathrm{N}$. tanajoae isolates from Brazil and Africa and that they are useful to monitor the establishment and spread of the Brazilian isolates of $N$. tanajoae introduced into Benin or into other African countries for improvement of CGM biocontrol.
\end{abstract}


Keywords: Mononychellus tanajoa, Neozygites tanajoae, molecular differentiation, microbiological control, Cassava

\section{Introduction}

The fungal pathogen Neozygites tanajoae Delalibera Jr., Humber \& Hajek (Zygomycetes: Entomophthorales) is being used in Africa as a biological control agent against the introduced cassava green mite (CGM), Mononychellus tanajoa (Bondar) (Acari: Tetranychidae). This fungus was initially referred to as Neozygites sp. (Delalibera et al. 1992) and later as Neozygites floridana (Oduor et al. 1995, Keller 1997, Elliot et al. 2000). Since 1988, when this pathogen was first found in Brazil, considerable data have been accumulated on the epizootiological, morphological and physiological aspects of strains from Brazil, Colombia and Benin (West Africa). Knowledge about CGM-pathogenic Neozygites has been well documented. Consistent differences appeared with $N$. floridana (Weiser \& Muma) Remaud. \& Keller, which has been found to be a common pathogen of many tetranychid mites. Indeed, N. tanajoae is specific to CGM (Delalibera et al. 2004) and has been therefore released as a biocontrol agent at various sites in West African cassava fields. Post-release monitoring in Benin has shown much higher infection rates in CGM populations in release fields compared to pre-release infection rates (Delalibera 2002, Hountondji et al. 2002a). However, although observations from experimental release fields provided evidence for establishment and better performance of the Brazilian isolates, accurate techniques for differentiating $N$. tanajoae isolates from post-release field collections were lacking. Morphological observations of $N$. tanajoae isolates from Brazil generally revealed similarities with $N$. floridana and also with other mite pathogenic species of Neozygites, including African strains (Delalibera et al. 2004). Furthermore, phenotypic similarities occurred also among fungal species coexisting in the same habitat. In the search for means to separate different isolates or species of the fungus, molecular tools were thought to help in overcoming the weaknesses of the phenotypic diagnostic methods ('e.g.' Lee et al. 1993; Bonants et al. 1997; Brasier et al. 1999; Judelson and Tooley, 2000). Therefore, molecular techniques have been recently put in place for the differentiation of $N$. tanajoae isolates from Brazil and Africa (Delalibera et al. 2004). PCR assays based on amplification of the ITS region of the ribosomal DNA (18S rDNA) and Random Amplified Polymorphic DNA (RAPD) techniques with several primers were tested to differentiate $N$. tanajoae isolates, however without success (Delalibera et al. 2004). Alternatively, an Amplified Fragment Length Polymorphism (AFLP) technique that integrates 
larger parts of the genome and that is able to detect even minor differences was developed (Delalibera 2002). As a result, oligonucleotide primers for PCR based detection of $N$. tanajoae have been designed that are capable of both differentiating this fungus from other fungal organisms and to distinguish Brazilian from African isolates. However, the development of these probes was based on Brazilian strains and the only African strain, which was collected in Benin. In the present study, we aimed at validating these probes on a larger collection of isolates from several locations in Brazil and on indigenous strains from Benin, Ghana and Tanzania collected before the introduction of Brazilian strains of N. tanajoae to West Africa

\section{Materials and methods}

\section{Fungal isolates}

Of the 18 isolates (Table 1) used in this study, three were obtained recently from Brazil (collected by G.J. de Moraes in 2007), while the remaining 15 were received from the International Institute of Tropical Agriculture (IITA, Biological Control

Table 1. Viability of Neozygites tanajoae on various mite samples tested with the in vivo sporulation assay

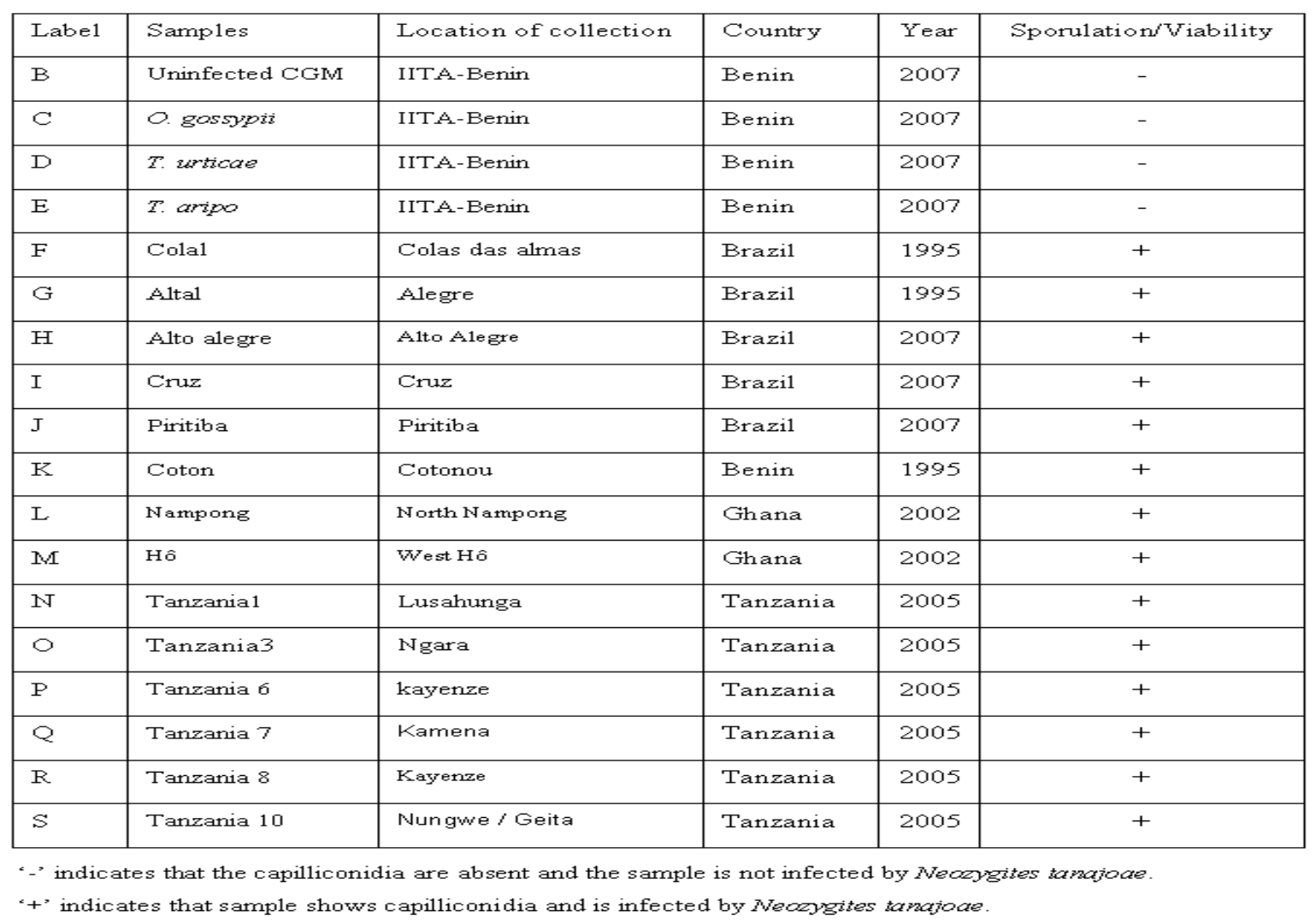


Center for Africa in Benin). Among the 15 isolates, 2 were supposed to be also of Brazilian origin (labelled Altal and Colal) that had been subcultured at IITA in preparation for field releases. These two isolates were imported by IITA from Alto Alegre and Cruz das Almas (both in state of Bahia in Brazil) in 1995 and kept in culture on M. tanajoa. The remaining 13 isolates were collected through IITA by R. Hanna from Ghana, Tanzania and Benin. Uninfected mites (Mononychellus tanajoa, Oligonychus gossypii, Tetranychus urticae and Typhlodromalus aripo) were used as negative controls for the species-specific primers. The isolates were preserved at $4{ }^{\circ} \mathrm{C}$ as hyphal bodies in mummified mites on dry cotton wool inside tightly sealed vials containing glycerol in the laboratory of the Division of Plant Pathology and Plant Protection at the Georg-August University, Germany. To prevent loss of fungal viability, cultures were renewed at approximately six-month intervals by infecting healthy mites (in vivo culture; see below).

\section{Viability testing of samples by sporulation test}

A laboratory test for viability was conducted at the Division of Plant Pathology and Plant Protection in Göttingen, Germany, during 2006/2007 with each of the 18 isolates used in this study. Viability was assessed with a sporulation test, in which at least five CGM mummies per fungal isolate were incubated singly on a cassava leaf disc $(1.5 \mathrm{~cm}$ in diameter $)$ placed on a moist cotton pad on the bottom of a plastic bottle $(190 \times 150 \times 50 \mathrm{~mm})$. Bottles were placed in a climate chamber for 24 hours at $19 \pm 1{ }^{\circ} \mathrm{C}, 95 \pm 5 \% \mathrm{RH}$ and $12 \mathrm{~h}: 12 \mathrm{~h}$ (light : dark) photoperiod as used successfully for $N$. tanajoae sporulation by Oduor et al. (1996). After 24 hours of incubation, mummies were checked under the binocular microscope for sporulation ('e.g.' production of capilliconidia). The presence of spores released on leaf discs was an indicator of sample viability. Isolates for which at least 5 mummies sporulated were considered viable. Viable samples were multiplied in vivo (see below) and stored separately for DNA extraction.

\section{In vivo multiplication of $N$. tanajoae}

Members of the genus Neozygites (Gustafsson, 1965; Le Rü et al. 1985; Saito et al. 1989), and particularly $N$. tanajoae (Delalibera et al. 2003), are difficult to culture on artificial media. Although in vitro culture of $N$. floridana is possible (Butt and Humber, 1989; Leite et al. 2000), attempts to grow N. tanajoae on the same media as used for $N$. floridana from $T$. urticae were not successful (Delalibera et al. 2003). Therefore, N. tanajoae isolates used for DNA extraction were obtained by in vivo production following Dara et al. (1998b). $M$. 
tanajoa killed and mummified by N. tanajoae were put on cassava leaf discs under conditions to enable fungal sporulation as described above. At the end of this period, leaf discs were checked under a compound microscope, and those found with capilliconidia (infective $N$. tanajoae spores) spread over about two thirds of the leaf disc surface were retained for CGM exposure. Twenty healthy adult females of $M$. tanajoa were exposed to capilliconidia on each leaf disc inside 150-mm diameter Petri dishes containing moist cotton wool and incubated at $28^{\circ} \mathrm{C}$ under a $12 \mathrm{~h}: 12 \mathrm{~h}$ light-dark regime for $24 \mathrm{~h}$ for infection. After 4 to 7 days, fresh mummies were collected and stored for use in DNA extraction. These experimental conditions normally resulted in a 60 to $70 \%$ infection rate (Dara et al. 1998a; Hountondji et al. 2002b). With this technique, large numbers of freshly infected mites (mummies) were produced and immediately stored at $4{ }^{\circ} \mathrm{C}$ or at $-20^{\circ} \mathrm{C}$ for long-term storage depending on when they were to be used for DNA extraction.

\section{Preparation of samples for DNA extraction}

A single mummified mite was used for DNA extraction because of the unavailability of pure fungal material. Each mummified or non-infected mite cadaver was placed inside a PCR tube $(0.5 \mathrm{ml})$ containing $10 \mu \mathrm{l}$ of autoclaved distilled water. The PCR tubes were then covered with a thermal adhesive sealing film and left at $25^{\circ} \mathrm{C}$ overnight to soften the cadavers and to promote sporulation by the fungus (I. Delalibera, unpublished). Nucleic acids of each sample were extracted using the InstaGene ${ }^{\mathrm{TM}}$ Matrix, Easy DNA kit (Bio-Rad Laboratories, Hercules, CA). DNA extraction followed the manufacturer's instructions for fungal tissues with slight modifications. The same procedure was used for DNA preparation from uninfected mites that were used as negative controls. A total of 180 samples (10 replicate samples from each of 18 isolates) was prepared for PCR analysis.

In the following step of DNA extraction, 50-100 $\mu 1$ of InstaGene Matrix (Bio-Rad Laboratories, Hercules, CA) were added to each PCR tube $(0.5 \mathrm{ml})$ using a $1 \mathrm{ml}$ pipette tip. Total DNA of each isolate was extracted from the sample prepared with InstaGene Matrix according to the manufacturer's instructions given for fungal DNA extraction. The procedure was as follows: the content of PCR tubes $(0.5 \mathrm{ml})$ was incubated at $56^{\circ} \mathrm{C}$ for $15-30 \mathrm{~min}$, vortexed at high speed for $10 \mathrm{~s}$ and were placed at $100^{\circ} \mathrm{C}$ in a boiling water bath for $8 \mathrm{~min}$, then vortexed again at high speed for $10 \mathrm{~s}$ and centrifuged at $10000-12000 \mathrm{rpm}$ for 2-3 min. Finally, the DNA was dissolved in $20-40 \mu 1$ of the resulting supernatant, saved in a new tube and stored at $-20^{\circ} \mathrm{C}$ until use. 


\section{PCR for detection and differentiation of Neozygites tanajoae isolates}

The genomic DNA obtained from uninfected and infected mites was used in a PCR assay with a pair of primers, NEOSSU_F / NEOSSU_R, designed for identification of N. tanajoae using 18S rRNA sequences from different isolates of the fungus (I. Delalibera et al. unpublished). The primer sequences of NEOSSU_F were 5'-GGT TTG ATT CCG GAG ATG GA-3' and of NEOSSU_R 5'-ATA CAA CCT GCT AAG GC T GCA-3'. The amplification reactions were performed in a PTC- $100^{\mathrm{TM}}$ thermocycler (MJ Research, Inc.) in $25-\mu 1$ volume containing $0.2 \mu \mathrm{l}$ each of forward and reverse primers $(20 \mu \mathrm{M}), 12.5 \mu \mathrm{l}$ of Promega Master Mix (Promega PCR Master Mix, 2X: 50 units/ml of Taq DNA Polymerase supplied in a commercial reaction buffer: $\mathrm{pH} 8.5,400 \mu \mathrm{M}$ of each dATP, dGTP, dCTP and dTTP, $3 \mathrm{mM} \mathrm{MgCl} 2$ ), $10.1 \mu 1$ of nuclease-free water (deionised) and $2 \mu 1$ of DNA sample pipetted into $23 \mu \mathrm{l}$ of PCR master mix. The sterile deionised water and DNA of uninfected mites were used as negative controls and in this case, $2 \mu 1$ of corresponding DNA from an uninfected mite and $2 \mu 1$ of sterile water (instead of template DNA) were pipetted into the 0.5 $\mathrm{ml}$ microcentrifuge tube containing $23 \mu \mathrm{l}$ of PCR master mix. All reaction components, except for the primers, were purchased from MBI Fermentas (St. Leon Roth, Germany). Thermocycler reactions were programmed as follows: hot start at $94^{\circ} \mathrm{C}$; initial denaturation at $94^{\circ} \mathrm{C}$ for $4 \mathrm{~min}$; 38 cycles of denaturation at $94^{\circ} \mathrm{C}$ for $1 \mathrm{~min}$; annealing at $50^{\circ} \mathrm{C}$ or $52^{\circ} \mathrm{C}$ for $1.5 \mathrm{~min}$, and extension at $72^{\circ} \mathrm{C}$ for $2.5 \mathrm{~min}$; final extension at $72{ }^{\circ} \mathrm{C}$ for $5 \mathrm{~min}$ and cool down to $8^{\circ} \mathrm{C}$. The PCR product was stored at $-20^{\circ} \mathrm{C}$ until use.

Differentiation of Brazilian and African isolates was done with the oligonucleotide primer pair 8DDC_F / 8DDC_R. The primer sequences were based on the sequencing of a randomly amplified polymorphic DNA fragment proven to be specific for Brazilian isolates (Delalibera et al. unpublished data). The respective primers were based on the sequence elements 8DDC_F: 5'-TCG TGT TGG AAG CAC GTT TA-3' and 8DDC_R: 5'-TTG ACG AAA TAG AGG CGA AAA-3'. PCR conditions and amplicon storage followed the same protocol as for the procedure described above for NEOSSU primers.

In addition, both oligonucleotide primer pairs NEOSSU_F / NEOSSU_R and 8DDC_F / 8DDC_R were combined in a multiplex PCR for detection and differentiation of fungal samples. For this reaction, PCR amplification was performed under the same conditions as described above.

All PCR analyses were performed and reproduced at least six times for each DNA sample under two annealing temperatures $\left(50^{\circ} \mathrm{C}\right.$ or $\left.52^{\circ} \mathrm{C}\right)$. The photographed bands that were 
consistently amplified were scored. GeneRuler ${ }^{\mathrm{TM}} 100 \mathrm{bp}$ ladder Plus (Fermentas, St. Leon Roth, Germany) was used as the DNA size marker.

To visualize amplicons, $10 \mu 1$ of the PCR products from each isolate were loaded in a gel containing $1.5 \%$ agarose in $0.5 \mathrm{x}$ TBE buffer (Tris $\mathrm{pH} 8$, boric acid, EDTA). Gels were run for $1 \mathrm{~h}$ at $60 \mathrm{~V}$, stained with ethidium bromide, visualized with UV light and photographed.

\section{Results}

\section{Viability of samples}

A series of 180 DNA extracts was tested derived from 18 mite samples infected or uninfected with different isolates of $N$. tanajoae in order to check the specificity of the two pairs of $N$. tanajoae primers (Table 1). Samples exposed to sporulation conditions showed two types of responses. The first type consisted of dead cadaver mites with absence of capilliconidia (Table 1). These were dead uninfected mites from different species (Mononychellus tanajoa, Olygonychus gossypii, Tetranychus urticae and Typhlodromalus aripo) and represented the negative control for primer evaluation. The second type comprised 14 isolates with the presence of capilliconidia representing infected CGM mites which were used as positive controls in the primer evaluation.

\section{PCR product optimization using specific primers}

The optimal annealing temperature, a critical factor for optimal PCR product formation, differed with the template-primer system (Peres et al. 2006). PCR analysis performed for each DNA sample with two annealing temperatures $\left(50^{\circ} \mathrm{C}\right.$ or $\left.52^{\circ} \mathrm{C}\right)$ indicated that the highest yields of specific products based on NEOSSU and 8DDC primers were obtained at $52^{\circ} \mathrm{C}$, where all expected bands were clearly developed. At $50^{\circ} \mathrm{C}$, only faint non-specific bands were detected (image not shown).

\section{Evaluation of species-specific primers NEOSSU}

The NEOSSU primer pair was evaluated for its ability to detect DNA from $N$. tanajoae in a matrix of mite cadavers and to differentiate uninfected from infected mites (mummies). Among 180 DNA samples obtained from 18 mite samples (10 separate DNA extracts per sample origin) which included African isolates, Brazilian isolates and uninfected mites, NEOSSU primers amplified only DNA from infected mites (Table 2). PCR amplification of DNA from infected mites with (NEOSSU_F / NEOSSU_R) resulted in reproducible bands of 
the expected size ( $800 \mathrm{bp}$ ) with 140 DNA samples out of 180 samples tested, thus separating the total of 14 infected mites (African and Brazilian isolates) from DNA samples from uninfected mites (Figure 1). Thus, the NESSOU primers yielded clear and specific amplicons for DNA of $N$. tanajoae at $52^{\circ} \mathrm{C}$ annealing temperature (Table 2, Figure 1).

\section{Evaluation of 8DDC primers for differentiating the origin of fungal strains}

The 8DDC_F / 8DDC_R primer pair was evaluated for the differentiation of Brazilian and African isolates in samples that had been previously tested positive

Table 2. Isolates of Neozygites tanajoae amplified by the two specific pairs of primers NEOSSU_F / NEOSSU_R and 8DDC_F / 8DDC_R in a polymerase chain reaction (PCR) at $52^{\circ} \mathrm{C}$ annealing temperature.

\begin{tabular}{|c|c|c|c|c|c|c|}
\hline Label & Samples & Location of collection & Countity & Viability & NEOSSU & $8 D D C$ \\
\hline $\mathrm{B}$ & Uninfected CGM & IITA-Berinin & Benin & not infected & - & - \\
\hline C & O. gosspipii & IITA-Benin & Benin & not infected & - & - \\
\hline $\mathrm{D}$ & T. anticae & IITA-Berini & Benin & not infected & - & - \\
\hline $\mathrm{E}$ & T. aripo & IIT $A_{-}$-Benin & Benin & not infected & - & - \\
\hline $\mathrm{F}$ & Colal & Colas das almas & Brazil & Infected & + & + \\
\hline$G$ & A.ltal & Alegre & Brazil & Infected & + & + \\
\hline $\mathrm{H}$ & Alto alegre & Alto Alegre & Brazil & Infected & + & + \\
\hline I & Ctuz & Ctuz & Brazil & Infected & + & + \\
\hline $\mathrm{J}$ & Piritiba & Piritiba & Brazil & Infected & + & + \\
\hline $\mathrm{K}$ & Coton & Cotonou & Benin & Infected & + & - \\
\hline $\mathrm{L}$ & Nampong & Notth Nampong & Ghana & Infected & + & - \\
\hline $\mathrm{MI}$ & Hồ & WTest Hô & Ghana & Infected & + & - \\
\hline $\mathrm{N}$ & Tanzania 1 & Lusahunga & Tanzania & Infected & + & - \\
\hline 0 & Tanzania 3 & Ngara & Tanzania & Infected & + & - \\
\hline $\mathrm{P}$ & Tanzania 6 & kayenze & Tanzania & Infected & + & - \\
\hline$Q$ & Tanzania 7 & Katnena & Tanzania & Infected & + & - \\
\hline $\mathrm{R}$ & Tanzania 8 & Kayenze & Tanzania & Infected & + & - \\
\hline$s$ & Tanzania 10 & Nungwe / Geita & Tanzania & Infected & + & - \\
\hline
\end{tabular}

-indicates that the concemed prime rs have not atmplified DVA of suspected sample.

+ indicates that the coneemed primets atmplified DNA sample.

for the presence of $N$. tanajoae. Among the 14 isolates scored as positive by the NEOSSU primer pair, DNA of five isolates was amplified with the 8DDC primer pair yielding a typical band of $600 \mathrm{bp}$ (Figure 2). In fact, all the five isolates detected in this PCR were of Brazilian origin (samples Colal, Altal, Alto Alegre, Cruz and Piritiba) whereas the DNA from the nine 
remaining isolates did not amplify with $8 \mathrm{DDC}$, as well as uninfected mites as negative control (Table 2, Figure 2).

\section{Evaluation of primer pairs in a multiplex PCR}

In the multiplex reaction with NEOSSU and 8DDC primers, all samples from isolates of $N$. tanajoae which were found viable during the sporulation test yielded the species-specific 800 bp amplicon with the NEOSSU primer pair (Figure 3). In contrast, neither sterile water nor DNA samples from uninfected mites displayed the 800 bp $N$. tanajoae diagnostic band (Figure 3). In addition, only Brazilian isolates of $N$. tanajoae produced a second band at 600 bp with the 8DDC primers in the PCR reaction (Figure 3).

\section{Discussion}

The objective of our research was to test DNA probes for identifying and differentiating $N$. tanajoae isolates collected from a broader range of locations, allowing for a large-scale analysis of the entomopathogen population in the cassava-growing regions of the world. For this, we used an international collection of $N$. tanajoae isolates collected from Brazil and three African countries: Benin, Tanzania and Ghana.

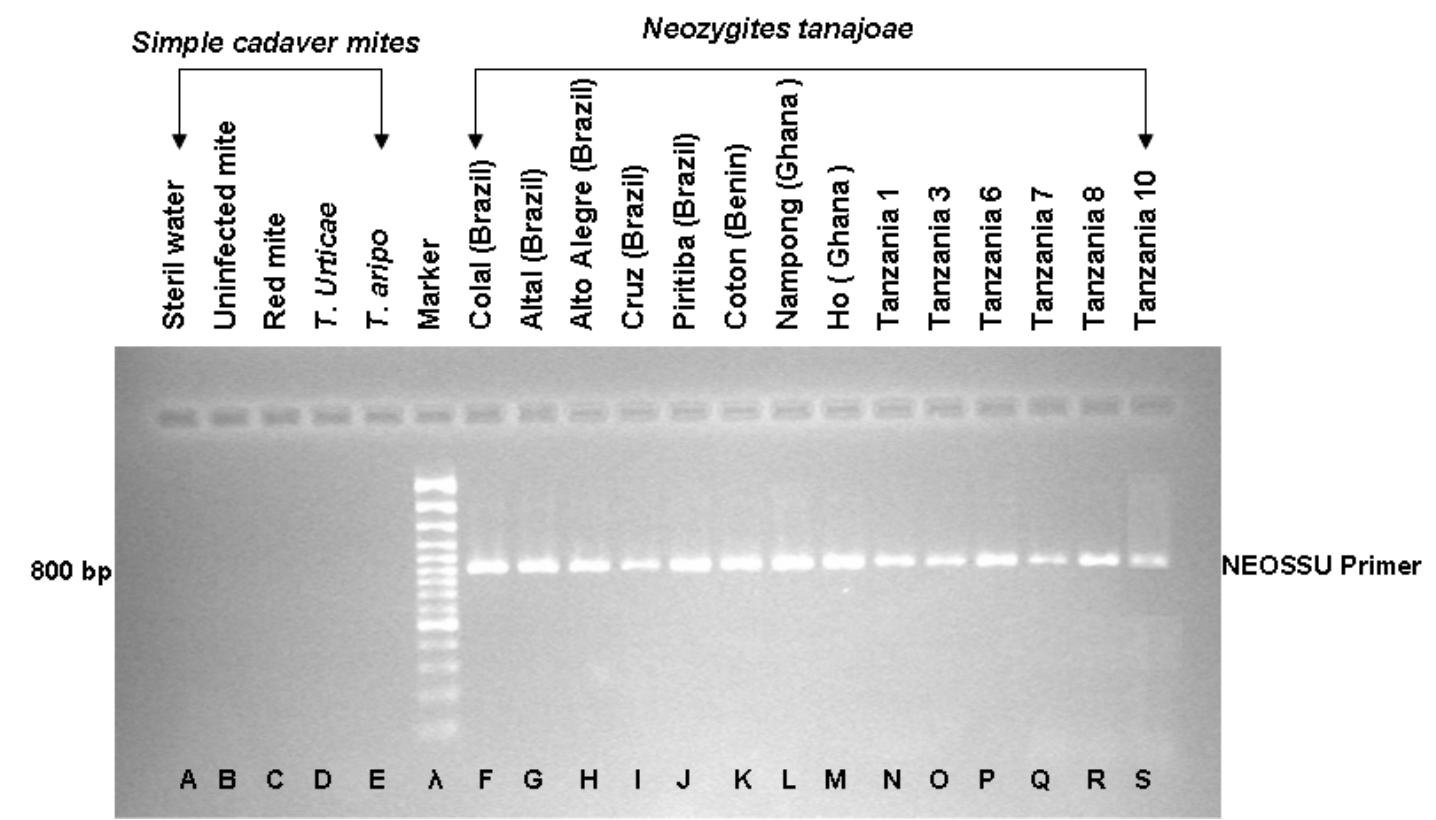

Figure 1. Detection of an 800-bp DNA fragment after polymerase chain reaction (PCR) using the oligonucleotide primers NEOSSU_F / NEOSSU_R species-specific to Neozygites tanajoae. Lanes F to S correspond to the amplified products while those from A to E represent the no amplified ones. The lane $\lambda$ is the marker lane. Red mite is Oligonychus gossypii and uninfected mite corresponds to non infected cadaver of the cassava green mite (CGM). 

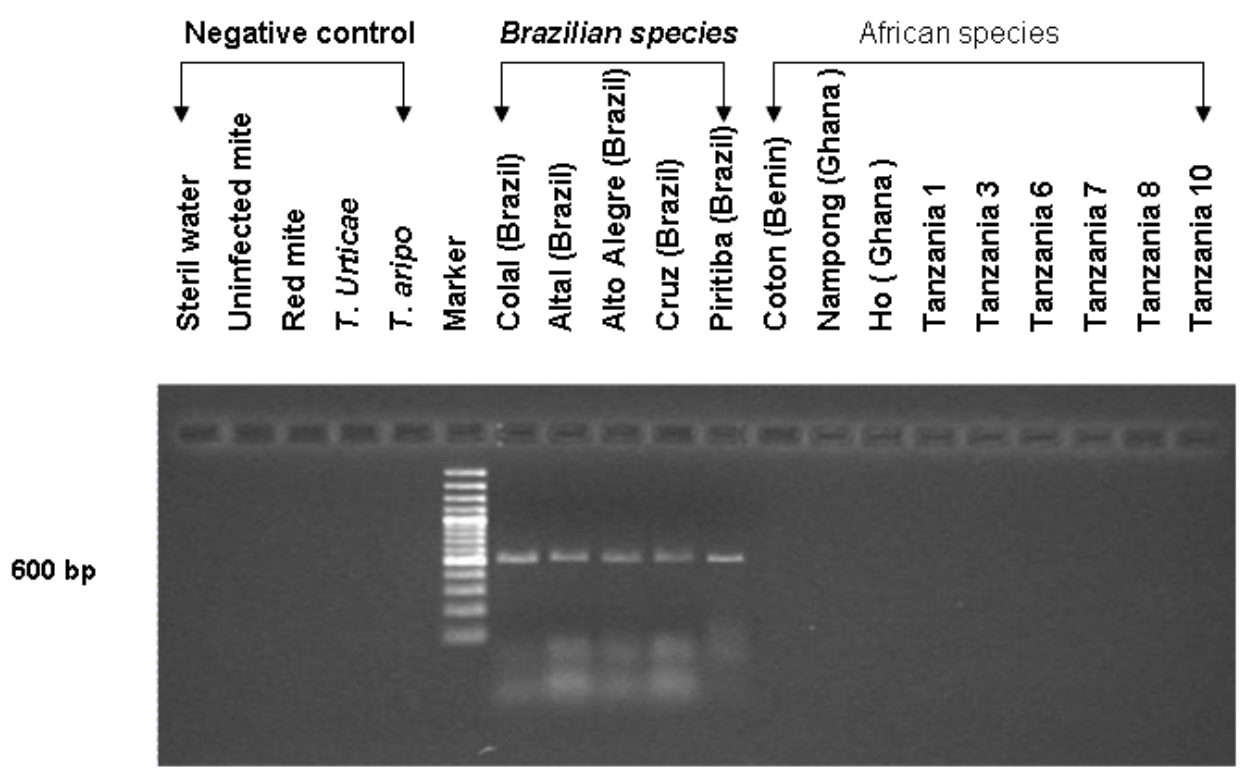

8DDC Primer

$\begin{array}{llllllllllllllllllll}A & B & C & D & E & \lambda & F & G & H & \text { I } & J & K & L & M & N & O & P & Q & R & S\end{array}$

Figure 2. Detection of a 600-bp DNA fragment after polymerase chain reaction (PCR) using the oligonucleotide primer pair 8DDC_F / 8DDC_R specific to Brazilian isolates of Neozygites tanajoae. Lanes F to J correspond to the amplified products with the Brazilian primer pair; lanes $\mathrm{K}$ to $\mathrm{S}$ correspond to African isolates that were not amplified with the same primer pair. Lane $\lambda$ is the marker lane. Red mite is Oligonychus gossypii and uninfected mite corresponds to a non infected cassava green mite cadaver (CGM)
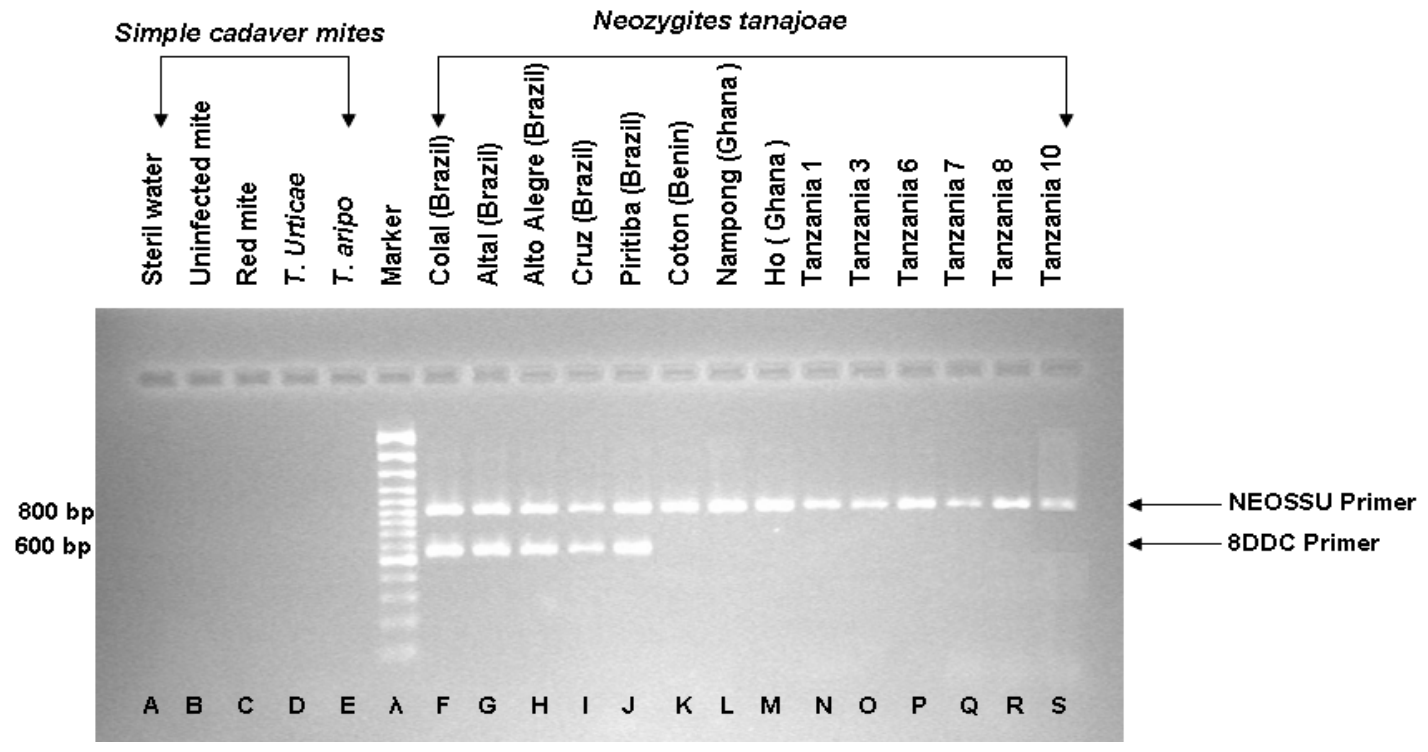

Figure 3. Detection of 800 and 600-bp DNA fragments after multiplex PCR using two pairs of oligonucleotide primers, one species-specific to Neozygites tanajoae (NEOSSU_F / NEOSSU_R) yielding 800-bp bands and the second (8DDC_F / 8DDC_R) specific for Brazilian isolates of N. tanajoae with 600-bp amplicons. Both amplification products were obtained from 5 isolates (lanes F-J) confirming the Brazilian origin of the isolates. The nine remaining samples (lanes K-S) were amplified only by NEOSSU primers confirming their assignment 
to isolates of $N$. tanajoae from outside Brazil. Lane $\lambda$ is the marker lane. Red mite is Oligonychus gossypii and uninfected mite corresponds to a non infected cassava green mite cadaver (CGM)

Molecular detection and differentiation of $N$. tanajoae is hampered by the fact that the fungus is extremely difficult to isolate and to culture on artificial media. Once pure cultures are available, they may be grown in fetal bovine serum, which is expensive and unavailable in many developing countries (Delalibera, et al. 2003). Therefore, in this study, DNA of $N$. tanajoae was obtained from in vivo-produced isolates, and a PCR assay was established capable of detecting fungal DNA within the complex matrix of infected mites. A similar example of conidia being successfully used for ITS-based PCR identification is the Leptosphaeria maculans species complex (Balesdent et al. 1998). Thus, mummified mites from several geographic regions in Brazil and Africa were tested for their capacity to produce infective capilliconidia of $N$. tanajoae, which was taken as characteristic of a viable sample. The sporulation test used in this study therefore served a dual purpose, as a suitable method for the detection of $N$. tanajoae infected mites and as a check for viability of the fungus.

It has been demonstrated that $N$. tanajoae associated with cassava green mite in Brazil and Africa is highly specific to its host and different geographical origins of the fungus cannot be distinguished with the available taxonomic tools based on fungal morphology (Delalibera 2002). The molecular markers used in this study were developed to overcome these constraints in order to enable reliable differentiation of African and Brazilian isolates of $N$. tanajoae. The present study independently validated the two primer pairs for the first time and determined that $52^{\circ} \mathrm{C}$ was a suitable annealing temperature in a PCR assay to materialize the specificity of the used primers.

The primary purpose of our study was to validate the probe developed by Delalibera et al. (unpublished data) using a pair of species-specific primers for $N$. tanajoae detection deduced from 18S rDNA sequences of different isolates of the fungus. In addition, a second pair was based on a RAPD fragment specific for Brazilian isolates, which suggested its utilization for separating Brazilian isolates among $N$. tanajoae isolates from African ones. Similar techniques have been used by Ersek et al. (2003) for identifying hybrids within Phytophthora alni with PCR-based DNA markers. In fact, PCR with genomic DNA extracted from mites infected with different strains of $N$. tanajoae produced a clear banding pattern while uninfected mites and sterile water did not produce any such signals (Figure 1). These results confirm the high specificity of NEOSSU primers as a key for $N$. tanajoae detection, thus confirming previous work by Delalibera et al. (unpublished) on a limited number of isolates. A similar study was conducted by Bonants et al. (2003) on detection and identification of 
Phytophthora fragariae with polymerase chain reaction by using species-specific primers. More importantly, the NEOSSU primer pair was also effective in detecting N. tanajoae in a complex natural matrix including infected mummified mites. Nonetheless, the successful amplification was only possible through the propagation of infective capilliconidia inside infected mummified mites under appropriate in vivo conditions prior to the PCR assay.

In addition, the 8DDC primer pair amplified only the five Brazilian strains among fourteen $N$. tanajoae isolates identified by NEOSSU on the species level before. The results indicate the specificity of this pair of primers to identify $N$. tanajoae isolates collected from different locations (Table 2). The nine remaining isolates not showing an 8DDC amplicon were all collected from various locations in Africa. However, compared with Delalibera et al. (unpublished data) more isolates from Africa (Benin, Ghana and Tanzania) were amplified by NEOSSU primers and did not amplify with 8DDC (Table 2), which supports the specificity of 8DDC primers to Brazilian strains. Although the number of isolates tested is still limited, we conclude that the 8DDC primer pair may serve as a reliable tool to separate Brazilian from African isolates in their natural habitat.

Finally, the multiplex PCR with both primer pairs together, further allowed us to show the effectiveness of NEOSSU and 8DDC primers for detecting and differentiating the Brazilian and African specimens of $N$. tanajoae in cassava green mite in one PCR run (Figure 3). Our findings also concur with earlier reports which demonstrated the power of multiplex PCR in the rapid identification of several pathogenic fungi in a complex matrix (Luo et al. 2002).

Altogether, this study demonstrates that $N$. tanajoae can effectively be propagated on mites with a sporulation assay in vivo and detected within the matrix by PCR, thus circumventing costly biochemical media and the problems incurred when isolating the entomopathogen from the saprotrophic colonizers of mummified mites. Thus, this assay also allows for a separation of simple dead uninfected mites collected in the field from mites infected with the entomopathogen.

The two oligonucleotide primer pairs are presently being used to follow the establishment and spread of Brazilian isolates already introduced into Benin (Hountondji et al. 2002a) and Tanzania (Hanna et al. unpublished data) and will be used in the future for following the establishment and spread of Brazilian isolates that will be introduced into other countries in sub-Saharan Africa in the framework of the campaign on biocontrol of the cassava green mite. 


\section{Acknowledgments}

This research was supported by the Deutscher Akademischer Austauschdienst (DAAD) fellowship, the International Institute of Tropical Agriculture (IITA) through a field work grant from the International Fund for Agricultural Development (IFAD), and by the University of Goettingen in Germany. Thanks to Dr Marie-Noelle Ndjiondjop of WARDA for making available her laboratory facilities, Dr Birger Koopmann for his multiple advice on the work, Drs. Alexis Onzo, Elisabeth Zannou, and Birger Koopmann for reviewing this manuscript, Honoré Dossounon, and Kevin Yènou for their technical assistance.

\section{Literature Cited}

Balesdent MH, Jedryczka M, Jain L, Mendes-Pereira E, Bertrandy J, Rouxel T. 1998. Conidia as a substrate for Internal Transcribed Spacer-Based PCR identification of members of the Leptosphaeria maculans species complex. Phytopathology 88: 1210-1217.

Bonants P, Hagenaar-de Weerdt M, van Gent-Pelzer M, Lacourt I, Cooke D, Duncan J. 1997. Detection and identification of Phytophthora fragariae Hickman by the polymerase chain reaction. European Journal of Plant Pathology 103: 345-355.

Bonants PJM, Carroll GC, DeWeerdt M, Van Brouwershaven IR, Baayen RP. 2003. Development and validation of a fast PCR-based detection method for pathogenic isolates of the citrus black spot fungus, Guignardia citricarpa. European Journal of Plant Pathology 109: 503-513.

Brasier CM, Cooke DEL, Duncan JM. 1999. Origin of a new Phytophthora pathogen through interspecific hybridization. Proceeding of the National Academy of Sciences 96: 58785883.

Butt TM, Humber RA. 1989. An immunofluorescence study of mitosis in a mite-pathogen, Neozygites sp. (Zygomycetes: Entomophthorales). Protoplasma 151: 115-123.

Dara SK, Lomer CJ, Hountondji FCC, Yaninek JS. 1998a. Fungal pathogens of mites on cassava: Field and laboratory studies. VII ${ }^{\text {th }}$ International Colloquium on Invertebrate Pathology and Microbial Control (abstract), Sapporo, Japan.

Dara SK, Lomer CJ, Hountondji FCC. 1998b. Releasing the entomopathogenic fungus, Neozygites floridana for cassava green mite control: an in vivo approach. $7^{\text {th }}$ Triennial Symposium of the International Society for Tropical Root Crops-Africa Branch (abstract), Cotonou, Benin. 
Delalibera JrI, Sosa Gomez DR, de-Moraes GJ, Alentar JA de, Farias Araujo W. 1992. Infection of Mononychellus tanajoa (Acari: Tetranychidae) by the fungus Neozygites sp. (Entomophthorales) in Northeastern Brazil. Florida Entomologist 75: 145-147.

Delalibera JrI. 2002. Investigations towards implementation of Neozygites tanajoae sp. Nov. as a classical biological control agent against the cassava green mite in Africa. $\mathrm{PhD}$. Thesis, Cornell University, Ithaca, New York, 141 pp.

Delalibera JrI, Hajek AE, Humber RA. 2003. Use of cell culture media for cultivation of the mite pathogenic fungi Neozygites tanajoae and Neozygites floridana. Journal of Invertebrate Pathology 84: 119-127.

Delalibera JrI, Hajek AE, Humber RA. 2004. Neozygites tanajoae sp. Nov, a pathogen of the cassava green mite. Mycologia 96: 1002-1009.

Elliot SL, de-Moraes GJ, Delalibera JrI, da-Silva CAD, Tamai MA, Mumford JD. 2000. Potential of the mite-pathogenic fungus Neozygites floridana (Entomophthorales: Neozygitaceae) for control of the cassava green mite Mononychellus tanajoa (Acari : Tetranychidae). Bulletin of Entomological Research 90: 191-200.

Ersek T, Bakonyi J, Nagy ZA. 2003. PCR-based marker for identification of interspecific Phytophthora hybrids attacking alder trees. In: Kövics Gy (ed), From Ideas to Implementation: Challenge and practice of Plant Protection in the Beginning of the $21^{\text {st }}$ Century. Proceedings $3^{\text {rd }}$ International Plant Protection Symposium. Debrecen, Hungary, Debrecen University, 2003, pp. 85-86.

Gustafsson M. 1965. On species of the genus Entomophthora Fres. in Sweden I: classification and distribution. Lantbrukshögskolans Annaler 31: 405-457.

Hountondji FCC, Lomer CJ, Hanna R, Cherry AJ, Dara SK. 2002a. Field evaluation of Brazilian isolates of Neozygites floridana (Entomophthorales: Neozygitaceae) for the microbial control of cassava green mite in Benin, West Africa. Biocontrol Science and Technology 12: 361-370.

Hountondji FCC, Yaninek JS, de-Moraes GJ, Oduor GI. 2002b. Host specificity of the cassava green mite pathogen Neozygites floridana. BioControl 47: 61-66.

Judelson HS, Tooley PW. 2000. Enhanced polymerase chain reaction methods for detecting and quantifying Phytophthora infestans in plants. Phytopathology 90: 1112-1119.

Keller S. 1997. The genus Neozygites (Zygomycetes, Entomophthorales) with special reference to species found in tropical regions. Sydowia 49: 118-146. 
Le Rü B, Silvie P, Papierok B. 1985. L'entomophthorale Neozygites fumosa pathogène de la cochenille du manioc, Phenacoccus manihoti (Homoptera: Pseudococcidae), en République populaire du Congo. Entomophaga 30: 23-29.

Lee SB, White TJ, Taylor JW. 1993. Detection of Phytophthora species by oligonucleotide hybridization to amplified ribosomal DNA spacers. Phytopathology 83: 177-181.

Leite LG, Smith L, de-Moraes GJ, Roberts DW. 2000. In vitro production of hyphal bodies of the mite pathogenic fungus Neozygites floridana. Mycologia 92: 201-207.

Luo G, Mitchell TG. 2002. Rapid Identification of pathogenic fungi directly from cultures by using multiplex PCR. Journal of Clinical Microbiology 40: 2860-2865.

Oduor GI, Yaninek JS, van der Geest LPS, de-Moraes GJ. 1995. Survival of Neozygites cf. floridana (Zygomycetes: Entomophthorales) in mummified cassava green mites and the viability of its primary conidia. Experimental and Applied Acarology 19: 479-488.

Oduor GI, de-Moraes GJ, van der Geest LPS, Yaninek JS. 1996. Production and germination of primary conidia of Neozygites floridana (Zygomycetes: Entomophthorales) under constant temperatures, humidities, and photoperiods. Journal of Invertebrate Pathology 68: 213-222.

Peres NA, Harakava R, Carroll GC, Adaskaveg JE, Timmer LW. 2006. Comparison of Molecular Procedures for Detection and Identification of Guignardia citricarpa and $G$. mangiferae. Plant Disease 91: 525-531.

Saito T, Kubota S, Shimazu M. 1989. A first record of entomopathogenous fungus, Neozygites parvispora (Macleod and Carl) Rem. And Kell. on Thrips palmi Karny (Thysanoptera: Thripidae) in Japan. Applied Entomology and Zoology 24: 233-235. 


\title{
Molecular detection of establishment and dispersal of Brazilian isolates of Neozygites tanajoae in Benin (West Africa) a fungus pathogenic to cassava green mite.
}

\author{
Bonaventure V. Agboton ${ }^{\bowtie 1,2}$; Rachid Hanna ${ }^{1}$; Andreas von Tiedemann ${ }^{2}$ \\ ${ }^{1}$ International Institute of Tropical Agriculture, 08 BP 0932, Cotonou, Republic of Benin \\ ${ }^{2}$ University of Göttingen, Department of Crop Sciences, Division of Plant Pathology and Crop Protection. \\ Grisebachstr. 6 D- 37077 Göttingen, Germany
}

\section{BioControl (2008, submitted)}

Corresponding author: Bonaventure V. Agboton; email: bogboton@yahoo.fr

\begin{abstract}
Molecular techniques were used to monitor the establishment and dispersal of Brazilian isolates of Neozygites tanajoae Delalibera, Humber \& Hajek (Entomophthorales: Neozygitaceae) released in Benin for the biological control of the cassava green mite, Mononychellus tanajoa (Bondar) (Acari: Tetranychidae). A total of 141 cassava fields were visited and samples of M. tanajoa suspected to be infected by $N$. tanajoae were collected in 60 fields distributed between the coastal Southern Forest Mosaic (SFM) and the Northern Guinea Savanna (NGS) zones of Benin, West Africa. Samples were analyzed using two specific primer sets, one species specific for $N$. tanajoae (NEOSSU) and another one specific for Brazilian isolates of this fungus (8DDC). Analysis of DNA samples of dead mites using the NEOSSU primers revealed the presence of $N$. tanajoae in 46 fields. The second specific pair of primers 8DDC revealed the presence of Brazilian isolates of N. tanajoae in 36 fields, representing $78.3 \%$ of fields positive for $N$. tanajoae. Brazilian isolates occurred from SFM to NGS zones in Benin, however, they were concentrated in fields located within former release zones (e.g. Department of Ouémé in the South and of Borgou in the North). In contrast, the indigenous African isolates of $N$. tanajoae were evenly distributed in the sub-humid and humid savannah zones of the country. However, mean infection rate of M. tanajoa with indigenous isolates of $N$. tanajoae was relatively low (5.3\%) compared to Brazilian isolates (28\%), indicating a higher biocontrol potential of the latter. This first post-release monitoring using PCR technique showed that Brazilian strains of $N$. tanajoae have been well established in Benin and spread effectively in this area.
\end{abstract}

Keywords: Entomopathogenic fungi; biocontrol; Neozygites tanajoae; Mononychellus tanajoae; Manihot esculenta 


\section{Introduction}

The cassava green mite (CGM), Mononychellus tanajoa (Bondar) (Acari: Tetranychidae), a native to South America was accidentally introduced into sub-Saharan Africa in the early 1970s causing significant reduction in crop yields (30-80\%) and threatening food security throughout much of the African cassava belt (Lyon 1973; Herren and Bennett 1984; Yaninek and Herren 1988). Numerous species of arthropod-pathogenic fungi are known to cause naturally-occurring epizootics that may decimate host population in the native region of cassava green mite. The possibility of introducing biological control agents from South America into Africa was since investigated. Neozygites tanajoae Delalibera, Hajek \& Humber (Entomophthorales: Neozygitaceae), one of the most efficient natural enemies of the CGM in Brazil (Delalibera 2002) was introduced experimentally into Benin (West Africa) in $1998 / 1999$ for the biocontrol of cassava green mite. $N$. tanajoae is highly specific to CGM as it is not known to infect any other host (Delalibera et al. 2004). N. tanajoae isolates from Brazil are morphologically similar to mite pathogenic isolates in Africa and other countries in South America (Delalibera and Hajek 2004). Post-release monitoring conducted in an experimental field in Benin in 2000 revealed the highest infection rates on the plots with the Brazilian isolates compared with the indigenous ones (Hountondji et al. 2002). However, although observations from experimental release fields gave vague evidence of establishment and better performance of the Brazilian isolates, no reliable techniques were available for differentiating these isolates of $N$. tanajoae from the indigenous (African) ones among postrelease field collections. Moreover, no post-release field studies were conducted to differentiate $N$. tanajoae isolates in the field and to monitor their effective establishment in West Africa. Until recently, such studies were hampered by a lack of techniques to reliably separate introduced from indigenous isolates in the field. Molecular tools may overcome this shortcoming of traditional (epizootiological and phenotypical) diagnostic methods (e.g. Lee et al. 1993; Bonants et al. 1997; Brasier et al. 1999; Judelson and Tooley 2000). Polymerase chain reaction (PCR)-based techniques have become widely used for the detection of plant pathogens (Gachon et al. 2004; Lievens et al. 2005; McCartney et al. 2003) as well as pathogens of herbivores (Tigano et al. 2006; Baek et al. 1998; Peres et al. 2006). Therefore, two specific pairs of oligonucleotide primers have been recently designed for PCR detection of $N$. tanajoae and the differential determination of the geographic origin of isolates of the fungus from Brazil and Africa. In previous works (Agboton et al. submitted), the primers have been evaluated with the result that they were suitable for identifying and monitoring Brazilian isolates on infested mites. 
In the present study we tested the molecular techniques to monitor the establishment and dispersal of Brazilian isolates of $N$. tanajoae that were released in cassava fields in Benin as biocontrol agents against M. tanajoa. This is the first major study on the occurrence, establishment and distribution of Brazilian isolates of $N$. tanajoae in the main cassava production areas in Benin as compared to indigenous isolates of the fungus. Information obtained by this study will be a key element for an appropriate post- release monitoring of $N$. tanajoae and improve follow-up strategies for the biocontrol of CGM African cassava fields.

\section{Materials and methods}

\section{Survey routes and sample collection}

The surveys were conducted in January, April and July 2007 and covered ten of the twelve departments in Benin. During these surveys, a total of 141 cassava fields were visited. The survey routes were selected across the main cassava-growing areas to include as many cassava fields for sampling as possible. Along the routes, cassava fields were visited at intervals of 10 to $15 \mathrm{~km}$ in southern Benin, where cassava fields are more frequent. In the north, where cassava fields are more sparse, sampling intervals were about 20 to $30 \mathrm{~km}$. Geographic latitude and longitude coordinates were recorded from each cassava field using a handheld Global Positioning System (GPS-Magellan 2000 XL) in order to map the distribution of Neozygites tanajoae isolates in Benin. In each field, 30 plants were randomly selected and the first fully expanded leaf collected from each plant. The leaves were placed separately in a paper bag and incubated in an icebox (at about $8^{\circ} \mathrm{C}$ ) overnight for inducing the mummification process of accompanying mites. After the incubation, leaves were examined under the dissecting microscope. Dead mummified mites suspected to be infected with $N$. tanajoae were collected from the leaves and mounted on microscope slides in lactophenol Amman's blue stain and examined under a phase contrast microscope for the presence of pathogens. The numbers of living CGM and dead CGM infected by $N$. tanajoae were recorded. If mummified dead mites were found the field was considered colonized by $N$. tanajoae and sampled mites were collected from the leaves and stored at $4^{\circ} \mathrm{C}$ in Eppendorf tubes $(2 \mathrm{ml})$ on dry cotton wool on top of silica gel. Rate of infection was calculated per field according to the number of leaves with presence of mites infected with the entomopathogenic fungus. 


\section{Sample preparation and DNA extraction}

Ten random samples of dead mites from the 60 sampled fields where $N$. tanajoae was suspected after the microscopic check were used for DNA extraction. Mummified mites were placed each individually in a PCR plate well $(0.5 \mathrm{ml})$. Each sample was thoroughly submersed in $10 \mu \mathrm{l}$ of autoclaved distilled water. The PCR plate with the cadavers was covered with an adhesive sealing film and incubated at $25^{\circ} \mathrm{C}$ overnight. This allowed the cadavers to soften and the fungus to sporulate. In total, 600 samples of suspected mummified mites were prepared for DNA extraction. All the fields and locations from where isolates were sampled and analysed during this study are listed in Table 1.

Genomic DNA was extracted using the InstaGene ${ }^{\mathrm{TM}}$ Matrix, Easy DNA kit (Bio-Rad Laboratories, Hercules, CA, USA), following the procedure described by the manufacturer for fungal DNA extraction. InstaGene ${ }^{\mathrm{TM}}$ Matrix $(50-100 \mu \mathrm{l})$ was added to each PCR tube $(0.5 \mathrm{ml})$. DNA was dissolved in $20-40 \mu 1$ of the resulting supernatant which was saved and stored at $20^{\circ} \mathrm{C}$ until use. From each sampled field, 10 independent DNA samples were prepared from infected mites.

\section{PCR analysis of field samples}

All samples in this study were analysed by PCR assays using the two specific pairs of primers tested previously (Agboton et al. submitted), which have been proven to be suitable for detection of $N$. tanajoae species and differential identification of Brazilian isolates of the fungus. Therefore, DNA samples extracted from field collections were checked by PCR using at first NEOSSU_F / NEOSSU_R primers for N. tanajoae species detection followed by 8DDC_F / 8DDC_R for Brazilian isolates identification. Each DNA sample was examined with PCR using separately the two primer pairs. PCR amplification was performed in a PTC$100^{\mathrm{TM}}$ thermocycler (MJ Research, Inc.) in a $25-\mu 1$ volume containing specific primers $(0.4$ $\mu 1)$, Promega Master Mix (12.5 $\mu 1)$, nuclease-free water $(10.1 \mu 1)$ and $2 \mu 1$ of DNA sample. Sterile deionised water and DNA extracted from uninfected cassava green mite cadavers were used as negative controls. Amplification was performed using the following conditions: Set up the thermocycler to hot start at $94^{\circ} \mathrm{C}$, initial denaturation at $94^{\circ} \mathrm{C}$ for 4 min, 38 cycles of denaturation at $94^{\circ} \mathrm{C}$ for $1 \mathrm{~min}$, annealing at $52^{\circ} \mathrm{C}$ for $1 \mathrm{~min} 30 \mathrm{~s}$ and extension at $72^{\circ} \mathrm{C}$ for 2 min 30s, final extension at $72^{\circ} \mathrm{C}$ for $5 \mathrm{~min}$, cool down at $8^{\circ} \mathrm{C}$ and storing of the PCR product at $-20^{\circ} \mathrm{C}$ until use. To visualize the DNA amplicons, $10 \mu 1$ of the PCR products from each isolate was loaded on a gel containing $1.5 \%$ agarose in $0.5 \mathrm{X}$ TBE buffer. Gels were run for 1 hour at 3 Volt $/ \mathrm{cm}$, stained with ethidium bromide, visualized with UV light and photographed. 
GeneRulerTM100bp ladder Plus was used as DNA size marker and consistently amplified bands were scored for data analysis. All reaction components except for the primers were purchased from MBI Fermentas (St. Leon Roth, Germany).

\section{Data analysis and isolate mapping}

Proportions of infected mites were normalized by arcsine-transformation and used to estimate the rate of infection. Average numbers of mites and percent infection were obtained using PROC MEANS of SAS software (SAS, Institute 2007, Inc, Cary, NC, USA). Mapping of the distribution of $N$. tanajoae and mainly Brazilian isolates within Benin was done with ARCVIEW software associated with African boundary data using the corresponding GPS coordinates.

\section{Results}

\section{Survey on distribution of $N$. tanajoae}

The survey covered the whole country of Benin except for the Sudan Savannah Zone where cassava is not produced. Within the 10 provinces covered, a total of 141 cassava fields were surveyed, ranging from the coastal Southern Forest Mosaic (SFM) to the Northern Guinea Savannah (NGS) vegetation zones (Fig. 1). Out of the 141 cassava fields surveyed, mite samples suspected of $N$. tanajoae infection were found and collected in 60 cassava fields representing 9 departments in the SFM and NGS agro-ecological zones, except Atacora (Table 1 and 2). However, infection rates of $M$. tanajoa by the fungus were not uniform across the surveyed fields. While in some fields infection rates were low (1\%) they exceeded 97\% in other fields (Table 1). The highest infection rates were observed in the departments of Mono, Ouémé, Collines and Borgou, with 95.6\%, 96.7\%, 78.6\% and 89.7\%, respectively (Table 1). The first two departments where the infection rates were the highest are located in the SFM zones while the two others are in the NGS zones (Fig. 1).

\section{Molecular detection of $N$. tanajoae of native and Brazilian origin}

All samples yielding an amplicon of the expected size following PCR with NEOSSU primers were considered as positive for $N$. tanajoae infection and those amplified with 8DDC primers were considered positive for Brazilian species of $N$. tanajoae (Table 1).

Out of 60 fields sampled, 46 were positive for the presence of $N$. tanajoae indicated by amplicons of 800 bp with the species-specific primer pair (NEOSSU) (Fig. 2; A1, B1, C1, 
D1). Samples from the remaining 14 fields showed no PCR bands with NEOSSU primers, indicating a lack of $N$. tanajoae in those fields (Fig. 2; A1, B1, C1, D1).

Further investigations of DNA samples from the 46 fields tested positive for the presence of $N$. tanajoae with additional 8DDC primers revealed 36 fields indicating the presence of Brazilian isolates on these sites (Table 1; Fig. 2; A2, B2, C2, D2). Thus, the double amplification generated by NEOSSU and 8DDC primers (Table 1; Fig. 2) enabled the detection and differentiation of Brazilian strains of $N$. tanajoae on real field samples (Agboton et al. in submission). In conclusion, 36 fields were tested positive for Brazilian isolates representing $78.3 \%$ of all fields where $N$. tanajoae was detected.

The number of fields with presence of $N$. tanajoae was high in Mono, Oueme, Colline and Borgou (7 fields at least), while in the other departments the highest number of positive fields was 4 (amplification with NEOSSU; Table 2). Overall, the 46 fields tested positive for the presence of $N$. tanajoae represented $76.7 \%$ of the 60 fields sampled for PCR investigation.

\section{Geographic distribution of Brazilian isolates in Benin}

The 36 fields with presence of Brazilian isolates of $N$. tanajoae were distributed from the SFM zone to the NGS zones and more or less concentrated around to the former release points (Table 2; Fig. 1). While Brazilian isolates of $N$. tanajoae were present in 9 of the 10 departments surveyed, none was observed in the Atacora department (Table 2). The number of fields with presence of Brazilian isolates was higher in Mono, Ouémé, Collines and Borgou departments compared to the other departments (Table 2). In fact, the Brazilians strains were more present throughout the humid and seasonally moist agro-ecological zones of the cassava growing regions in Benin than in the drier zones (Fig. 1). Moreover, a significant correlation was obtained between the rate of CGM infection with the entomopathogen and the prevalence of Brazilian isolates in cassava fields ( $p<0.01$ and $\left.R^{2}=0.755\right)$ (Fig. 3).

\section{Discussion}

The results presented here provide the evidence of the establishment and dispersal in Benin of Brazilian strains of $N$. tanajoae found associated with the cassava green mite upon PCR detection with specific primers. Our results also showed that the PCR assay with specific markers is sensitive enough to detect the infection of cassava green mites by $N$. tanajoae as sampled from commercial cassava fields. This accurate detection and identification of DNA samples with PCR using specific primer pairs demonstrates that Brazilian and African isolates of $N$. tanajoae are genetically diverse, although morphologically similar and can be separated 
with molecular techniques. A similar molecular approach has been used by Nakabonge et al. (2006) on different pathogens of Chrysoporthe spp. to follow their distribution in Eastern and Southern Africa. Indeed, PCR-based techniques have become widely used for the detection of plant pathogens (Gachon et al. 2004; Lievens et al. 2005; McCartney et al. 2003) as well as herbivore pathogens (Baek et al. 1998; Tigano et al. 2006; Peres et al. 2006).

With the aid of molecular detection methods the present study provides a first insight into distribution in Benin of the most important entomopathogen of Mononychellus tanajoa currently known. This is the first time that molecular markers were used for monitoring the status of $N$. tanajoae dispersal in Benin, where the Brazilian isolates have been released in 1999. Our PCR results showed that $N$. tanajoae was present in 46 out of 60 fields proving that the fungus has reached a wide geographic distribution in Benin. The absence of $N$. tanajoae in the Department of Atacora may be due to the relatively short rainy season, a dryer season and the scarcity of cassava fields in this department (Yaninek et al. 1991). While N. tanajoae was present in nine provinces, its occurrence on CGM was not homogenous among all sampled fields. Similar to the finding of Yaninek et al. (1996), this suggests that certain locations may be more favourable for the establishment and survival of the pathogen (Larsen et al. 2007) and infection of CGM. Moreover, the number of cassava fields associated with N. tanajoae was higher in the south where the agro-ecological conditions are more favourable for cassava production.

After having been released in Benin in January 1999 to control CGM (Hountondji et al. 2002), the main constraint to follow establishment and dispersal of the Brazilian isolates of $N$. tanajoae was the lack of reliable tools of detection and distinguishing them from endogenous African strains. In the present field evaluation the molecular markers developed and tested in our previous work confirmed their potential to solve that problem. The results presented here provide the first molecular detection of Brazilian isolates of $N$. tanajoae released in commercial cassava fields in Benin.

The present results reveal the successful establishment and dispersal of Brazilian isolates throughout the seasonally humid ecological zones of the cassava agro-ecosystems in Benin. According to Yaninek et al. (1996) the annual precipitation is generally greater in southern than northern Benin that could enhance the fungal growth and may explain the higher infection rates found in southern Benin. Oduor et al. (1995) demonstrated that the determining factors of an epizooty are the climatic conditions (temperature, humidity) governing infection of mites and the fungus survival. In Brazilian conditions, nearly $100 \%$ of the adult female 
population of CGM has been shown to be infected with $N$. tanajoae depending on mite density, location, season and climate (Delalibera \& de Moraes, 1992).

The rate of $78.3 \%$ of Brazilian isolates recorded from samples infested with $N$. tanajoae in Benin provides evidence for the effective establishment and dispersal of those isolates in Africa, mainly in Benin. Most cassava fields with Brazilian isolates present were found around the former release regions in northern and southern Benin, however, nine years after the release of exotic isolates in only two departments, Ouémé (Adjohoun) and Borgou (Ina) in Benin, Brazilian isolates of $N$. tanajoae have spread to further 7 departments due to favourable environmental conditions in different regions in Benin.

Interestingly, overall infection rates of CGM were significantly correlated with the prevalence of Brazilian isolates in cassava fields indicating a stronger biocontrol potential of the exotic pathogen strains to the suppression of CGM populations. This is in contrast to laboratory studies which showed very little or no difference in virulence between the local African isolates of N. tanajoae and the introduced Brazilian isolates (Dara et al. 1998a). Additional studies on the specific biopotential of indigenous and exotic entomopathogenic strains on common CGM and their relatedness to environmental conditions in the cassava growing areas in Africa are required to further improve implementation and management of this biocontrol strategy in practical use.

\section{Acknowledgments}

We are grateful to the Deutscher Akademischer Austauschdienst (DAAD), the International Institute of Tropical Agriculture (IITA), for a field work grant from the International Fund for Agricultural Development (IFAD), and the University of Göttingen in Germany for supporting this research. Thanks are due to Italo Delalibera Jr, Birger Koopmann, Alexis Onzo, and Ignace Zannou for their advices on the work and their comments on an earlier version of the manuscript. 


\section{References}

Baek SCMD, Chae HJMD, Dong HMD, Byun DGMD, Cho BKMD (1998) Detection and differentiation of causative fungi of onychomycosis using PCR amplification and restriction enzyme analysis. Internat. J. Derm. 37: 682-686

Bonants P, Hagenaar-de WM, van Gent-Pelzer M, Lacourt I, Cooke D, Duncan J (1997) Detection and identification of Phytophthora fragariae Hickman by the polymerase chain reaction. Europ. J. P1. Pathol. 103: 345-355

Brasier CM, Cooke DEL, Duncan JM (1999) Origin of a new Phytophtora pathogen through interspecific hybridization. Proceedings of the National Academy of Sciences of the USA 96: $5878-5883$

Dara SK, Lomer CJ, Hountondji FCC, Yaninek JS (1998a) Fungal pathogens of mites on cassava: Field and laboratory studies. VIIth International Colloquium on Invertebrate Pathology and Microbial Control (abstract), Sapporo, Japan

Delalibera JrI, Sosa Gomez DR, de-Moraes GJ, Alentar JA de, Farias Araujo W (1992) Infection of Mononychellus tanajoa (Acari : Tetranychidae) by the fungus Neozygites sp. (Entomophthorales) in Northeastern Brazil. Florida Entomol. 75: 145-147

Delalibera JrI (2002) Investigations towards implementation of Neozygites tanajoae sp. nov. as a classical biological control agent against the cassava green mite in Africa. $\mathrm{PhD}$. Thesis, Cornell University, Ithaca, New York, 141 pp

Delalibera JrI, Hajek AE, Humber RA (2004) Neozygites tanajoae sp. nov, a pathogen of the cassava green mite. Mycologia 96: 1002-1009

Gachon C, Mingam A, Charrier B (2004) Real-time PCR: What relevance to plant studies? J. Exp. Bot. 55:1445-1454

Herren HR, Bennett FD (1984) Cassava pests, their spread and control. In: Advancing agricultural production in Africa, Arusha, Tanzania. Common Agricultural Bureau, Slough, UK.

Hountondji FCC, Lomer CJ, Hanna R, Cherry AJ, Dara SK (2002) Field evaluation of Brazilian isolates of Neozygites floridana (Entomophthorales: Neozygitaceae) for the microbial control of cassava green mite in Benin, West Africa. Biocont. Sc. Tech. 12: $361-370$

Judelson HS, Tooley PW (2000) Enhanced polymerase chain reaction methods for detecting and quantifying Phytophthora infestans in plants. Phytopath. 90: 1112-1119 
Larsen JE, Hollingsworth CR, Flor J, Dornbusch MR, Simpson NL, Samac DA (2007) Distribution of Phoma sclerotioides on alfalfa and winter wheat crops in the North Central United States. P1. Dis. 91: 551-558

Lee SB, White TJ, Taylor JW (1993) Detection of Phytophthora species by oligonucleotide hybridization to amplified ribosomal DNA spacers. Phytopath. 83:177-181

Lievens B, Thomma BPHJ (2005) Recent developments in pathogen detection arrays: Implications for fungal plant pathogens and use in practice. Phytopath. 95: 1374-1380

Lyon WF (1973) A plant-feeding mite Mononychellus tanajoa Bondar (Acarina: Tetranychidae) new to the African continent threatens cassava (Manihot esculenta Crantz) in Uganda, East Africa. Pest. Artic. And News Summ. 19: 36-37

McCartney HA, Foster SJ, Fraaije BA, Ward E (2003) Molecular diagnostics for fungal plant pathogens. Pest Manag. Sci. 59: 129-142

Nakabonge G, Roux J, Gryzenhout M, Wingfield MJ (2006) Distribution of Chrysoporthe canker pathogens on Eucalyptus and Syzygium spp. in eastern and southern Africa. Pl. Dis. 90: $734-740$

Oduor GI, Yaninek JS, van der Geest LPS, de-Moraes GJ (1995) Survival of Neozygites cf. floridana (Zygomycetes: Entomophthorales) in mummified cassava green mites and the viability of its primary conidia. Exp. Appl. Acarol.19: 479-488

Peres NA, Harakava R, Carroll GC, Adaskaveg JE, Timmer LW (2006) Comparison of molecular procedures for detection and identification of Guignardia citricarpa and $G$. mangiferae. P1. Dis. 91: 525-531

SAS Institute 2007. SAS system for Windows, Statistics. Release 6.12, version 9.1. SAS Institute Inc, Cary, NC, USA

Tigano MS, Adams B, Maimala S, Boucias D (2006) Genetic diversity of Hirsutella thompsonii isolates from Thailan AFLP analysis and partial $\beta$-tubulin gene sequences. Genetics and Molecular Biology. doi: 10.1590/S1415-47572006000400022

Yaninek JS, Baumgaertner J, Gutierrez AP (1991) Sampling the cassava green mite, Mononychellus tanajoa (Bondar), in Africa. Bull. Entomol. Res. 81: 201- 208

Yaninek JS, Saizonou S, Onzo A, Zannou I, Gnanvossou D (1996) Seasonal and habitat variability in the fungal pathogens: Neozygites cf. floridana and Hirsutella thompsonii, associated with cassava mites in Benin. Biocont. Sc. Tech. 6: 23-33

Yaninek JS, Herren HR (1988) Introduction and spread of the cassava green mite, Mononychellus tanajoa (Bondar) (Acari: Tetranychidae), an exotic pest in Africa and the search for appropriate control methods: a review. Bull. Entomol. Res. 78:1-13 
Table 1. N. tanajoae infection rates of CGM (M. tanajoa) within cassava fields in Benin related to the presence of Brazilian isolates detected by species-specific primers (NEOSSU) and differentiated by country specific primers (8DDC; + and - correspond to the presence and absence of amplified bands, respectively)

\begin{tabular}{|c|c|c|c|c|c|c|c|c|}
\hline \multirow{2}{*}{$\begin{array}{l}\text { Field } \\
\text { code }\end{array}$} & \multirow[b]{2}{*}{ Location surveyed } & \multirow[b]{2}{*}{ Department } & \multicolumn{2}{|c|}{ GPS } & \multirow{2}{*}{$\begin{array}{c}\text { Infection } \\
\text { rate (\%) }\end{array}$} & \multirow{2}{*}{$\begin{array}{l}\text { DNA } \\
\text { code }\end{array}$} & \multicolumn{2}{|c|}{ PCR test } \\
\hline & & & Longitude & Latitude & & & NEOSSU & $8 \mathrm{DDC}$ \\
\hline F1 & $12 \mathrm{~km} \mathrm{~N} \mathrm{Come}$ & Mono & 1.84 & 6.48 & 14.20 & 1 & + & - \\
\hline $\mathrm{F} 2$ & $4 \mathrm{~km} \mathrm{E} \mathrm{Se}$ & Mono & 1.86 & 6.48 & 2.75 & 2 & + & + \\
\hline F3 & $1 \mathrm{~km} \mathrm{~W} \mathrm{Se}$ & Mono & 1.81 & 6.53 & 67.28 & 3 & + & + \\
\hline F4 & $3 \mathrm{~km} \mathrm{~S}$ Atchannou & Mono & 1.75 & 6.56 & 8.90 & 4 & + & - \\
\hline F5 & $4 \mathrm{~km} \mathrm{~N} \mathrm{Se}$ & Mono & 1.82 & 6.54 & 3.15 & 5 & + & - \\
\hline F6 & Kpinnou (Epicentre) & Mono & 1.78 & 6.58 & 86.66 & 6 & + & + \\
\hline F7 & $1 \mathrm{~km} \mathrm{~S} \mathrm{Bopa}$ & Mono & 1.96 & 6.59 & 78.33 & 7 & + & + \\
\hline F8 & 2 km N Zoungbonou & Mono & 1.79 & 6.57 & 95.56 & 8 & + & + \\
\hline F9 & 3 km W Comé & Mono & 1.90 & 6.43 & 12.50 & 9 & + & + \\
\hline F10 & $0.7 \mathrm{~km}$ E Doutou & Mono & 1.89 & 6.57 & 24.10 & 10 & + & + \\
\hline F11 & 20 km N Comé & Mono & 1.84 & 6.49 & 0.73 & 11 & - & - \\
\hline F12 & Lokossa & Mono & 1.72 & 6.65 & 0.00 & $\mathrm{a}$ & & \\
\hline F13 & $3 \mathrm{~km}$ N Comé & Mono & 1.86 & 6.42 & 0.00 & $\mathrm{a}$ & & \\
\hline F14 & 17.2 km E Dogbo & Mono & 1.89 & 6.89 & 0.00 & $\mathrm{a}$ & & \\
\hline F15 & 13.9 km NE Lokossa & Mono & 1.77 & 6.76 & 0.00 & $\mathrm{a}$ & & \\
\hline F16 & $1 \mathrm{~km}$ E Doutou & Mono & 1.89 & 6.57 & 0.00 & $\mathrm{a}$ & & \\
\hline F17 & $2.8 \mathrm{~km} \mathrm{~W}$ Lalo & Mono & 1.87 & 6.94 & 0.00 & $\mathrm{a}$ & & \\
\hline F18 & $4 \mathrm{~km} \mathrm{~N}$ Akassato & Atlantique & 2.35 & 6.53 & 6.50 & 12 & + & + \\
\hline F19 & 8 km N Glodjegbé & Atlantique & 2.26 & 6.61 & 4.62 & 13 & - & - \\
\hline F20 & $22 \mathrm{~km} \mathrm{~S}$ Ouidah & Atlantique & 1.90 & 6.40 & 0.47 & 14 & + & + \\
\hline F21 & $9 \mathrm{~km} \mathrm{~S}$ Allada & Atlantique & 2.21 & 6.64 & 0.60 & 15 & - & - \\
\hline F22 & $1 \mathrm{~km} \mathrm{~N}$ Ouidah & Atlantique & 2.07 & 6.37 & 0.13 & 16 & - & - \\
\hline F23 & $9 \mathrm{~km} \mathrm{~S}$ Ouidah & Atlantique & 2.16 & 6.38 & 0.80 & 17 & + & + \\
\hline F24 & Pahou & Atlantique & 2.20 & 6.38 & 0.03 & 18 & + & - \\
\hline F25 & 9 km Sèdjè Dénou & Atlantique & 2.30 & 6.74 & 0.00 & $\mathrm{a}$ & & \\
\hline F26 & 4 km N Agon & Atlantique & 2.24 & 6.88 & 0.00 & $\mathrm{a}$ & & \\
\hline F27 & 3 km S Sèhouè & Atlantique & 2.26 & 6.92 & 0.00 & $\mathrm{a}$ & & \\
\hline F28 & 25 km S Sèhouè & Atlantique & 2.17 & 6.75 & 0.00 & $\mathrm{a}$ & & \\
\hline F29 & 2 km N Houégbo & Atlantique & 2.19 & 6.82 & 0.00 & $\mathrm{a}$ & & \\
\hline F30 & 36 km S Sèhouè & Atlantique & 2.15 & 6.67 & 0.00 & $\mathrm{a}$ & & \\
\hline F31 & 15 km S Sèhouè & Atlantique & 2.20 & 6.83 & 0.00 & $\mathrm{a}$ & & \\
\hline F32 & 13 km S Sékou & Atlantique & 2.31 & 6.55 & 0.00 & $\mathrm{a}$ & & \\
\hline F33 & 33 km N Parakou & Borgou & 2.69 & 9.71 & 6.76 & 19 & - & - \\
\hline F34 & $4.5 \mathrm{~km}$ Parakou & Borgou & 2.59 & 9.28 & 0.65 & 20 & + & - \\
\hline
\end{tabular}


Table 1 Continued (1)

\begin{tabular}{|c|c|c|c|c|c|c|c|c|}
\hline \multirow{2}{*}{$\begin{array}{l}\text { Field } \\
\text { code }\end{array}$} & \multirow[b]{2}{*}{ Location surveyed } & \multirow[b]{2}{*}{ Department } & \multicolumn{2}{|c|}{ GPS } & \multirow{2}{*}{$\begin{array}{c}\text { Infection } \\
\text { rate }\end{array}$} & \multirow{2}{*}{$\begin{array}{l}\text { DNA } \\
\text { code }\end{array}$} & \multicolumn{2}{|c|}{ PCR test } \\
\hline & & & Longitude & Latitude & & & NEOSSU & 8DDC \\
\hline F35 & $5 \mathrm{~km}$ Parakou & Borgou & 2.67 & 9.33 & 1.11 & 21 & + & - \\
\hline F36 & 30 km W Parakou & Borgou & 2.36 & 9.23 & 0.61 & 22 & + & + \\
\hline F37 & 16 km E Tchachou & Borgou & 2.70 & 9.08 & 11.97 & 23 & + & + \\
\hline F38 & 45 km W Parakou & Borgou & 2.23 & 9.21 & 3.25 & 24 & + & + \\
\hline F39 & $4 \mathrm{~km}$ E Bembereke & Borgou & 2.69 & 10.19 & 89.66 & 25 & + & + \\
\hline F40 & 6 km W N'Dali & Borgou & 2.68 & 9.83 & 18.49 & 26 & + & + \\
\hline F41 & Ina station & Borgou & 2.71 & 9.96 & 0.27 & 27 & - & - \\
\hline $\mathrm{F} 42$ & 139 km S Parakou & Borgou & 2.64 & 8.21 & 0.00 & $\mathrm{a}$ & & \\
\hline F43 & $15 \mathrm{~km} \mathrm{~W}$ Parakou & Borgou & 2.49 & 9.29 & 0.00 & $\mathrm{a}$ & & \\
\hline F44 & 17 km E Bemberekè & Borgou & 2.80 & 10.18 & 0.00 & $\mathrm{a}$ & & \\
\hline F45 & $3 \mathrm{~km} \mathrm{~S}$ Parakou & Borgou & 2.60 & 9.30 & 0.00 & $\mathrm{a}$ & & \\
\hline F46 & 88 km S Parakou & Borgou & 2.60 & 8.61 & 0.00 & $\mathrm{a}$ & & \\
\hline F47 & 47 km Parakou & Borgou & 2.70 & 9.77 & 0.00 & $\mathrm{a}$ & & \\
\hline F48 & $1 \mathrm{~km}$ N. Kpaouignan & Colline & 2.22 & 7.69 & 3.65 & 28 & + & + \\
\hline F49 & $9 \mathrm{~km} \mathrm{W.} \mathrm{Bétékoukou}$ & Colline & 2.36 & 7.76 & 8.50 & 29 & + & + \\
\hline F50 & $3 \mathrm{~km} \mathrm{~S}$. Bantè & Colline & 1.91 & 8.38 & 10.37 & 30 & - & - \\
\hline F51 & $1 \mathrm{~km}$ Alafia (Savè) & Colline & 2.64 & 8.20 & 1.75 & 31 & + & - \\
\hline F52 & $5 \mathrm{~km} \mathrm{S.} \mathrm{W} \mathrm{Savè}$ & Colline & 2.44 & 8.01 & 3.77 & 32 & + & + \\
\hline F53 & $80 \mathrm{Km}$ S Bassila & Colline & 1.84 & 8.46 & 78.57 & 33 & + & + \\
\hline F54 & $5 \mathrm{Km}$ N Bassila & Colline & 1.64 & 9.07 & 75.66 & 34 & + & + \\
\hline F55 & 8km N. Diho (Savè) & Colline & 2.56 & 8.12 & 7.85 & 35 & + & - \\
\hline F56 & $1 \mathrm{~km} \mathrm{~S}$ Dassa & Colline & 2.18 & 7.77 & 2.75 & 36 & + & + \\
\hline F57 & 109 km S Parakou & Colline & 2.60 & 8.44 & 0.00 & $\mathrm{a}$ & & \\
\hline F58 & 16 km W Dassa & Colline & 2.10 & 7.89 & 0.00 & $\mathrm{a}$ & & \\
\hline F59 & 52 km S Bassila & Colline & 1.68 & 8.61 & 0.00 & $\mathrm{a}$ & & \\
\hline F60 & $2 \mathrm{~km}$ N Savalou & Colline & 1.97 & 8.12 & 0.00 & $\mathrm{a}$ & & \\
\hline F61 & $56 \mathrm{~km}$ N Savalou & Colline & 1.96 & 8.28 & 0.00 & $\mathrm{a}$ & & \\
\hline F62 & $34 \mathrm{~km} \mathrm{~W} \mathrm{Savalou}$ & Colline & 1.71 & 7.84 & 0.00 & $\mathrm{a}$ & & \\
\hline F63 & $4.1 \mathrm{~km} \mathrm{SE}$ Adjohoun & Ouémé & 2.52 & 6.72 & 13.00 & 37 & + & - \\
\hline F64 & $1 \mathrm{~km} 7 \mathrm{SE}$ Adjohoun & Ouémé & 2.51 & 6.75 & 18.13 & 38 & + & + \\
\hline F65 & 40m Apres pillon & Ouémé & 2.50 & 6.70 & 13.32 & 39 & + & + \\
\hline F66 & $4 \mathrm{Km}$ NE Adjohoun & Ouémé & 2.49 & 6.73 & 56.75 & 40 & + & + \\
\hline F67 & $1 \mathrm{Km}$ E Adjohoun & Ouémé & 2.49 & 6.71 & 67.27 & 41 & + & + \\
\hline F68 & $3 \mathrm{~km}$ NE Adjohoun & Ouémé & 2.50 & 6.73 & 96.66 & 42 & + & + \\
\hline F69 & Azowlisse carefour & Ouémé & 2.51 & 6.65 & 18.56 & 43 & + & + \\
\hline F70 & $8 \mathrm{~km}$ E Adjohoun & Ouémé & 2.56 & 6.69 & 46.29 & 44 & + & + \\
\hline
\end{tabular}


Table 1 Continued (2)

\begin{tabular}{|c|c|c|c|c|c|c|c|c|}
\hline \multirow{2}{*}{$\begin{array}{l}\text { Field } \\
\text { code }\end{array}$} & \multirow[b]{2}{*}{ Location surveyed } & \multirow[b]{2}{*}{ Department } & \multicolumn{2}{|c|}{ GPS } & \multirow{2}{*}{$\begin{array}{c}\text { Infection } \\
\text { rate }\end{array}$} & \multirow{2}{*}{$\begin{array}{l}\text { DNA } \\
\text { code }\end{array}$} & \multicolumn{2}{|c|}{ PCR test } \\
\hline & & & Longitude & Latitude & & & NEOSSU & $8 \mathrm{DDC}$ \\
\hline F71 & $2.1 \mathrm{~km} \mathrm{SE}$ adjohoun & Ouémé & 2.50 & 6.71 & 15.27 & 45 & - & - \\
\hline F72 & 15 km N Onigbolo & Ouémé & 2.46 & 7.28 & 0.00 & $\mathrm{a}$ & & \\
\hline F73 & Missérété & Ouémé & 2.59 & 6.56 & 0.00 & $\mathrm{a}$ & & \\
\hline F74 & $1 \mathrm{~km}$ N Gbékandji & Ouémé & 2.55 & 6.69 & 0.00 & $\mathrm{a}$ & & \\
\hline F75 & 4km N Gbékandji & Ouémé & 2.56 & 6.86 & 0.00 & $\mathrm{a}$ & & \\
\hline F76 & $3 \mathrm{~km} \mathrm{~S}$ Tatonoukon & Ouémé & 2.49 & 6.91 & 0.00 & $\mathrm{a}$ & & \\
\hline F77 & $23 \mathrm{~km} \mathrm{~S}$ Tatonoukon & Ouémé & 2.48 & 6.81 & 0.00 & a & & \\
\hline F78 & $34 \mathrm{~km} \mathrm{~S}$ Tatonoukon & Ouémé & 2.49 & 6.73 & 0.00 & a & & \\
\hline F79 & Ayetedjou & Plateau & 2.72 & 6.66 & 0.77 & 46 & + & + \\
\hline F80 & $5 \mathrm{~km} \mathrm{~W}$ Igolo & Plateau & 2.70 & 6.68 & 0.83 & 47 & + & + \\
\hline F81 & $15 \mathrm{~km}$ N. Onigbolo & Plateau & 2.46 & 7.28 & 3.10 & 48 & - & - \\
\hline F82 & $61 \mathrm{~km}$ E Bohicon & Plateau & 2.56 & 7.27 & 0.13 & 49 & - & - \\
\hline F83 & $1 \mathrm{~km}$ N. Takon & Plateau & 2.62 & 6.66 & 5.49 & 50 & + & + \\
\hline F84 & $29 \mathrm{~km} \mathrm{~S}$ Pobè & Plateau & 2.62 & 6.79 & 0.00 & $\mathrm{a}$ & & \\
\hline F85 & $21 \mathrm{~km} \mathrm{~S}$ Pobè & Plateau & 2.63 & 6.94 & 0.00 & $\mathrm{a}$ & & \\
\hline F86 & $1 \mathrm{~km}$ E. Yoko & Plateau & 2.62 & 6.71 & 0.00 & $\mathrm{a}$ & & \\
\hline F87 & $30 \mathrm{~km} \mathrm{~S}$ Pobè & Plateau & 2.62 & 6.78 & 0.00 & $\mathrm{a}$ & & \\
\hline F88 & $3 \mathrm{~km}$ N. Ikpinlè & Plateau & 2.63 & 6.91 & 0.00 & $\mathrm{a}$ & & \\
\hline F89 & $43 \mathrm{~km} \mathrm{~S} \mathrm{Ketou}$ & Plateau & 2.66 & 7.01 & 0.00 & $\mathrm{a}$ & & \\
\hline F90 & 49 km S Pobè & Plateau & 2.61 & 6.65 & 0.00 & $\mathrm{a}$ & & \\
\hline F91 & 6km N Sakété & Plateau & 2.63 & 6.75 & 0.00 & $\mathrm{a}$ & & \\
\hline F92 & 8 km S Pobè & Plateau & 2.63 & 6.94 & 0.00 & $\mathrm{a}$ & & \\
\hline F93 & $4 \mathrm{~km} \mathrm{~S}$ Bonou & Plateau & 2.46 & 6.86 & 0.00 & $\mathrm{a}$ & & \\
\hline F94 & 4km W Ikpinlè & Plateau & 2.59 & 6.89 & 0.00 & $\mathrm{a}$ & & \\
\hline F95 & $10 \mathrm{~km} \mathrm{~S} \mathrm{Ketou}$ & Plateau & 2.63 & 7.28 & 0.00 & $\mathrm{a}$ & & \\
\hline F96 & $1 \mathrm{~km} \mathrm{S.} \mathrm{Massi}$ & Zou & 2.25 & 6.97 & 3.67 & 51 & + & + \\
\hline F97 & 2km E. Kotokpa & Zou & 2.19 & 7.09 & 3.24 & 52 & + & + \\
\hline F98 & $34 \mathrm{~km} \mathrm{~S} \mathrm{Dassa}$ & Zou & 2.12 & 7.55 & 0.17 & 53 & - & - \\
\hline F99 & $40 \mathrm{~km}$ E Bohicon & Zou & 2.41 & 7.23 & 0.07 & 54 & - & - \\
\hline F100 & $54 \mathrm{~km} \mathrm{~S}$ Dassa & Zou & 2.07 & 7.40 & 0.38 & 55 & - & - \\
\hline F101 & $22 \mathrm{~km}$ E Bohicon & Zou & 2.26 & 7.20 & 0.00 & $\mathrm{a}$ & & \\
\hline F102 & $23 \mathrm{~km}$ S Zogbodomey & Zou & 2.26 & 6.95 & 0.00 & $\mathrm{a}$ & & \\
\hline F103 & $2 \mathrm{~km}$ E. Avlamé & Zou & 2.15 & 7.10 & 0.00 & $\mathrm{a}$ & & \\
\hline F104 & $3 \mathrm{~km} \mathrm{~S}$ Zogbodomey & Zou & 2.13 & 7.05 & 0.00 & $\mathrm{a}$ & & \\
\hline F105 & $3 \mathrm{~km} \mathrm{~S} \mathrm{Djidja}$ & Zou & 1.85 & 7.31 & 0.00 & a & & \\
\hline F106 & $31 \mathrm{~km} \mathrm{~N}$ Bohicon & Zou & 2.07 & 7.45 & 0.00 & $\mathrm{a}$ & & \\
\hline
\end{tabular}


Table 1 Continued (3)

\begin{tabular}{|c|c|c|c|c|c|c|c|c|}
\hline \multirow{2}{*}{$\begin{array}{l}\text { Field } \\
\text { code }\end{array}$} & \multirow[b]{2}{*}{ Location surveyed } & \multirow[b]{2}{*}{ Department } & \multicolumn{2}{|c|}{ GPS } & \multirow{2}{*}{$\begin{array}{c}\text { Infection } \\
\text { rate }\end{array}$} & \multirow{2}{*}{$\begin{array}{l}\text { DNA } \\
\text { code }\end{array}$} & \multicolumn{2}{|c|}{ PCR test } \\
\hline & & & Longitude & Latitude & & & NEOSSU & 8DDC \\
\hline F107 & $4 \mathrm{~km}$ E Cove & Zou & 2.37 & 7.22 & 0.00 & $\mathrm{a}$ & & \\
\hline F108 & $500 \mathrm{~m} \mathrm{~W}$ Kinta & Zou & 2.03 & 7.08 & 0.00 & $\mathrm{a}$ & & \\
\hline F109 & $7 \mathrm{~km}$ N. Dan & Zou & 2.08 & 7.38 & 0.00 & $\mathrm{a}$ & & \\
\hline F110 & 9km SE Zogbodomey & Zou & 2.17 & 7.02 & 0.00 & $\mathrm{a}$ & & \\
\hline F111 & Bohicon / rondpoint & Zou & 2.09 & 7.17 & 0.00 & $\mathrm{a}$ & & \\
\hline F112 & $57 \mathrm{~km}$ S. Natitingou & Donga & 1.74 & 9.78 & 3.08 & 56 & + & + \\
\hline F113 & $75 \mathrm{~km} \mathrm{~W}$ Paoukon & Donga & 2.12 & 9.38 & 0.03 & 57 & - & - \\
\hline F114 & $1 \mathrm{~km} \mathrm{S.} \mathrm{W} \mathrm{Onklou}$ & Donga & 1.98 & 9.50 & 0.62 & 58 & + & + \\
\hline F115 & $0.5 \mathrm{~km} \mathrm{~S}$ Ouaké & Donga & 1.39 & 9.68 & 0.00 & $\mathrm{a}$ & & \\
\hline F116 & 10km W. Djougou & Donga & 1.57 & 9.68 & 0.00 & $\mathrm{a}$ & & \\
\hline F117 & $122 \mathrm{~km} \mathrm{~W} \mathrm{Parakou}$ & Donga & 1.79 & 9.59 & 0.00 & $\mathrm{a}$ & & \\
\hline F118 & 13km S. E Djougou & Donga & 1.76 & 9.62 & 0.00 & $\mathrm{a}$ & & \\
\hline F119 & 16km S.W Wewe I & Donga & 2.19 & 9.24 & 0.00 & $\mathrm{a}$ & & \\
\hline F120 & $21 \mathrm{~km} \mathrm{~S}$ Djougou & Donga & 1.64 & 9.53 & 0.00 & $\mathrm{a}$ & & \\
\hline F121 & $2 \mathrm{~km}$ E Patargo & Donga & 1.93 & 9.53 & 0.00 & $\mathrm{a}$ & & \\
\hline F122 & $2 \mathrm{~km}$ E. Djougou & Donga & 1.69 & 9.68 & 0.00 & $\mathrm{a}$ & & \\
\hline F123 & $2 \mathrm{~km}$ S. Pezebina & Donga & 1.64 & 9.46 & 0.00 & $\mathrm{a}$ & & \\
\hline F124 & $3 \mathrm{~km} \mathrm{~S}$ Djougou & Donga & 1.65 & 9.68 & 0.00 & $\mathrm{a}$ & & \\
\hline F125 & 45 km S Djougou & Donga & 1.57 & 9.36 & 0.00 & $\mathrm{a}$ & & \\
\hline F126 & $5 \mathrm{~km} \mathrm{~W} \mathrm{Djougou}$ & Donga & 1.62 & 9.69 & 0.00 & $\mathrm{a}$ & & \\
\hline F127 & 60km S. W Djougou & Donga & 2.12 & 9.37 & 0.00 & $\mathrm{a}$ & & \\
\hline F128 & 78 km S Djougou & Donga & 1.62 & 9.10 & 0.00 & $\mathrm{a}$ & & \\
\hline F129 & 12 km N Lokossa & Couffo & 1.77 & 6.74 & 2.15 & 59 & + & - \\
\hline F130 & $1 \mathrm{~km} \mathrm{~S}$ Atieme & Couffo & 1.68 & 6.59 & 0.10 & 60 & + & + \\
\hline F131 & $11 \mathrm{~km}$ N Dogbo & Couffo & 1.73 & 6.89 & 0.00 & $\mathrm{a}$ & & \\
\hline F132 & $46 \mathrm{~km} \mathrm{~N}$ Azove & Couffo & 1.95 & 7.17 & 0.00 & $\mathrm{a}$ & & \\
\hline F133 & $1 \mathrm{~km} \mathrm{~N} \mathrm{Dogbo}$ & Couffo & 1.77 & 6.82 & 0.00 & $\mathrm{a}$ & & \\
\hline F134 & $11 \mathrm{~km} \mathrm{S.} \mathrm{Azovè}$ & Couffo & 2.25 & 6.86 & 0.00 & $\mathrm{a}$ & & \\
\hline F135 & 12 km N Lokossa & Couffo & 1.77 & 6.74 & 0.00 & $\mathrm{a}$ & & \\
\hline F136 & 21 km N Azové & Couffo & 1.82 & 7.06 & 0.00 & $\mathrm{a}$ & & \\
\hline F137 & $3 \mathrm{~km} \mathrm{~S}$. Azovè & Couffo & 1.71 & 6.92 & 0.00 & $\mathrm{a}$ & & \\
\hline F138 & 7.6km W Klouékamè & Couffo & 1.81 & 7.04 & 0.00 & $\mathrm{a}$ & & \\
\hline F139 & 16km N.E Natitingou & Atacora & 1.46 & 10.41 & 0.00 & $\mathrm{a}$ & & \\
\hline F140 & 30km S Natitingou & Atacora & 1.50 & 10.01 & 0.00 & $\mathrm{a}$ & & \\
\hline F141 & $3 \mathrm{~km}$ N. Natitingou & Atacora & 1.39 & 10.34 & 0.00 & $\mathrm{a}$ & & \\
\hline
\end{tabular}

DNA code: (a) indicates fields in which no fungus was detected and therefore no DNA sample was tested ; DNA samples are numbered consecutively

Infection rate: Percentage of leaves $(n=30)$ per field carrying infected mites 
Table 2. PCR results on samples collected from 60 fields in different Departments of Benin in 2007, identified by PCR using NEOSSU and 8DDC primers

\begin{tabular}{|c|c|c|c|c|c|c|}
\hline \multirow{2}{*}{ Department } & \multirow{2}{*}{$\begin{array}{c}\text { No. of } \\
\text { fields } \\
\text { surveyed }\end{array}$} & \multirow{2}{*}{$\begin{array}{c}\text { No. of } \\
\text { sampled } \\
\text { fields*) }\end{array}$} & \multicolumn{2}{|c|}{$\begin{array}{l}\text { No. of fields with } \\
\text { amplicons for }\end{array}$} & \multirow{2}{*}{$\begin{array}{l}\text { Percentage of } \\
\text { fields with } \\
\text { infected } \\
\text { mites**) }\end{array}$} & \multirow{2}{*}{$\begin{array}{l}\text { Percentage of } \\
\text { fields with } \\
\text { Brazilian } \\
\text { isolates**) }\end{array}$} \\
\hline & & & NEOSSU & $8 \mathrm{DDC}$ & & \\
\hline Couffo & 10 & 2 & 2 & 1 & 20.00 & 10.00 \\
\hline Mono & 17 & 11 & 10 & 7 & 58.82 & 41.18 \\
\hline Atlantique & 15 & 7 & 4 & 3 & 26.67 & 20.00 \\
\hline Ouémé & 16 & 9 & 8 & 7 & 50.00 & 43.75 \\
\hline Plateau & 17 & 5 & 3 & 3 & 17.65 & 17.65 \\
\hline Zou & 16 & 5 & 2 & 2 & 12.50 & 12.50 \\
\hline Colline & 15 & 9 & 8 & 6 & 53.33 & 40.00 \\
\hline Borgou & 15 & 9 & 7 & 5 & 46.67 & 33.33 \\
\hline Dongo & 17 & 3 & 2 & 2 & 11.76 & 11.76 \\
\hline Atacora & 3 & 0 & 0 & 0 & 0.00 & 0.00 \\
\hline Total & 141 & 60 & 46 & 36 & & \\
\hline
\end{tabular}

*) Number of fields sampled per department (fields selected following microscopic check of mite infection; 10 independent samples were taken from each field and assayed with PCR)

**) Percentage of fields with presence of African or Brazilian isolates per department compared to the total number of surveyed fields. 


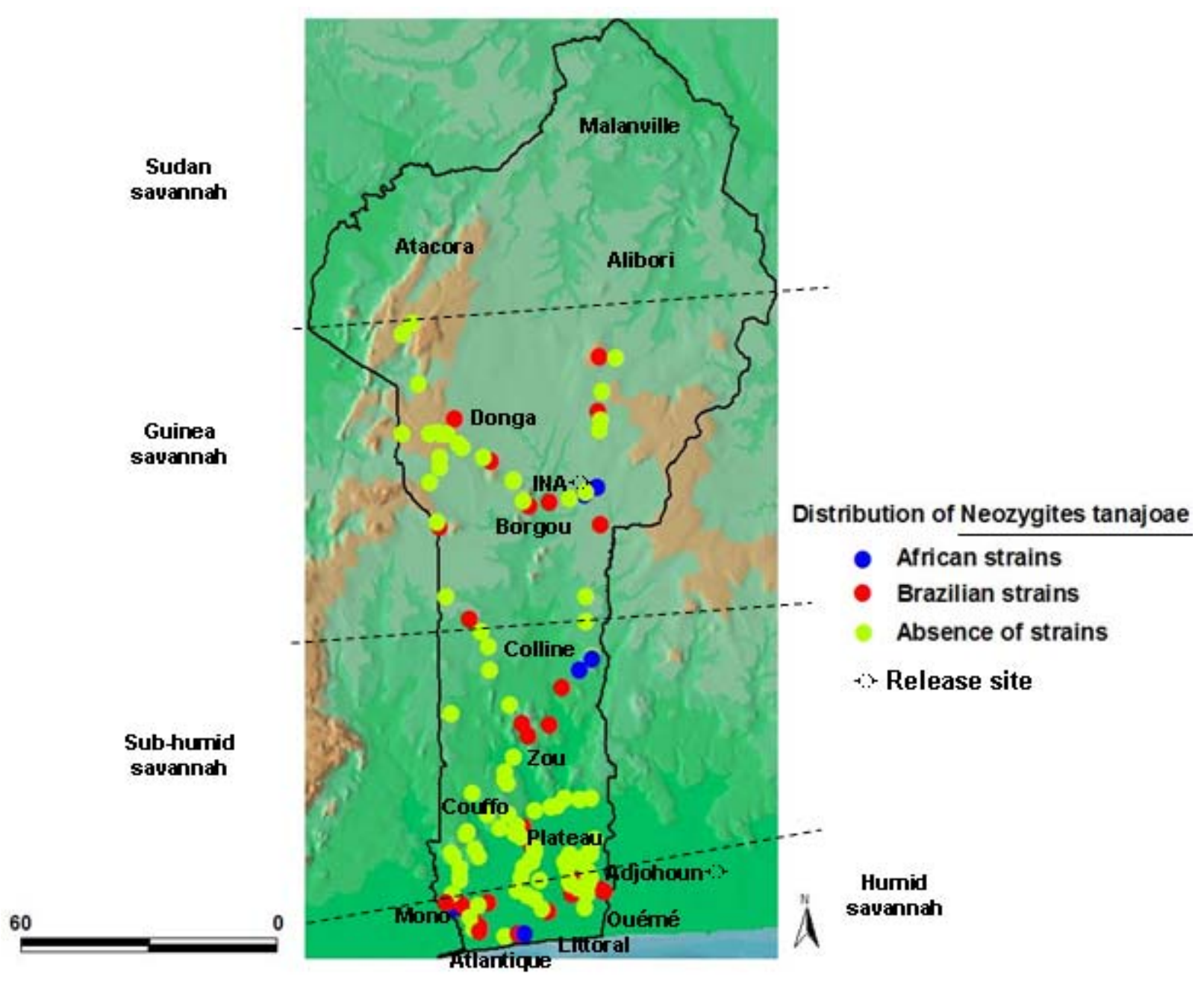

Figure 1. Distribution of African and Brazilian isolates of $N$. tanajoae associated with cassava green mite in different agroecological zones of Benin. Agroecological zones, departments, former release points, surveyed field sites and sample identification are indicated (scale bar gives distances in $\mathrm{km})$. 

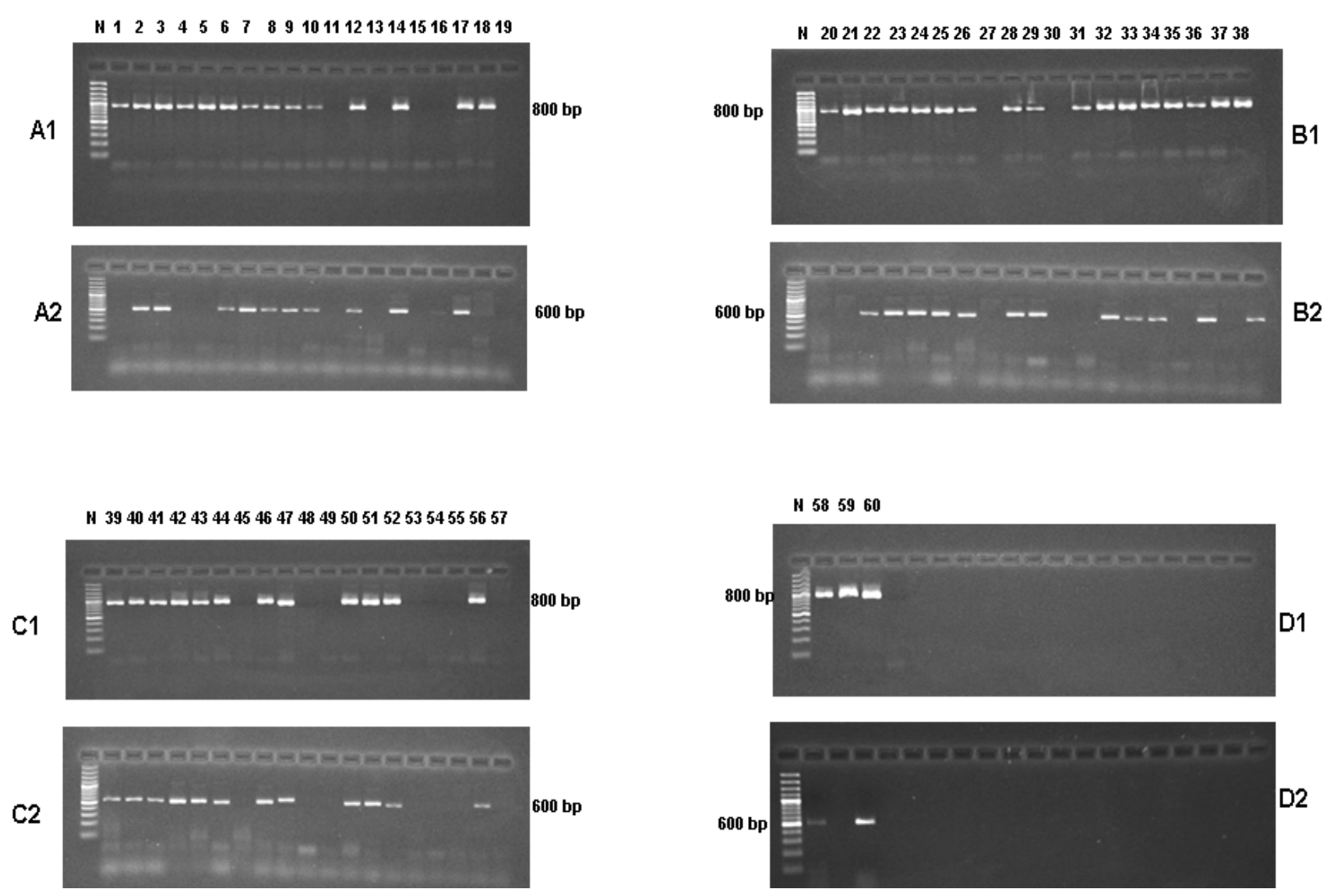

Figure 2. Polymerase chain reaction (PCR)-based detection of Neozygites tanajoae by species-specific oligonucleotide primer pair NEOSSU_F/NEOSSU_R (A1, B1, C1 and D1). $\mathrm{A} 1, \mathrm{~B} 1, \mathrm{C} 1$ and D1 show the species-specific amplicon of 800bp. Lanes are labelled corresponding to the field labels in Table 1. With primer pair 8DDC_F/8DDC_R specific to the Brazilian isolates, A2, B2, C2 and D2 show amplicons of 600bp indicating fields with presence of the exotic isolates. GeneRuler DNA ladder Mix (MBI Fermentas) is included in marker lane $\mathrm{N}$ (fragment sizes are indicated in bp). 


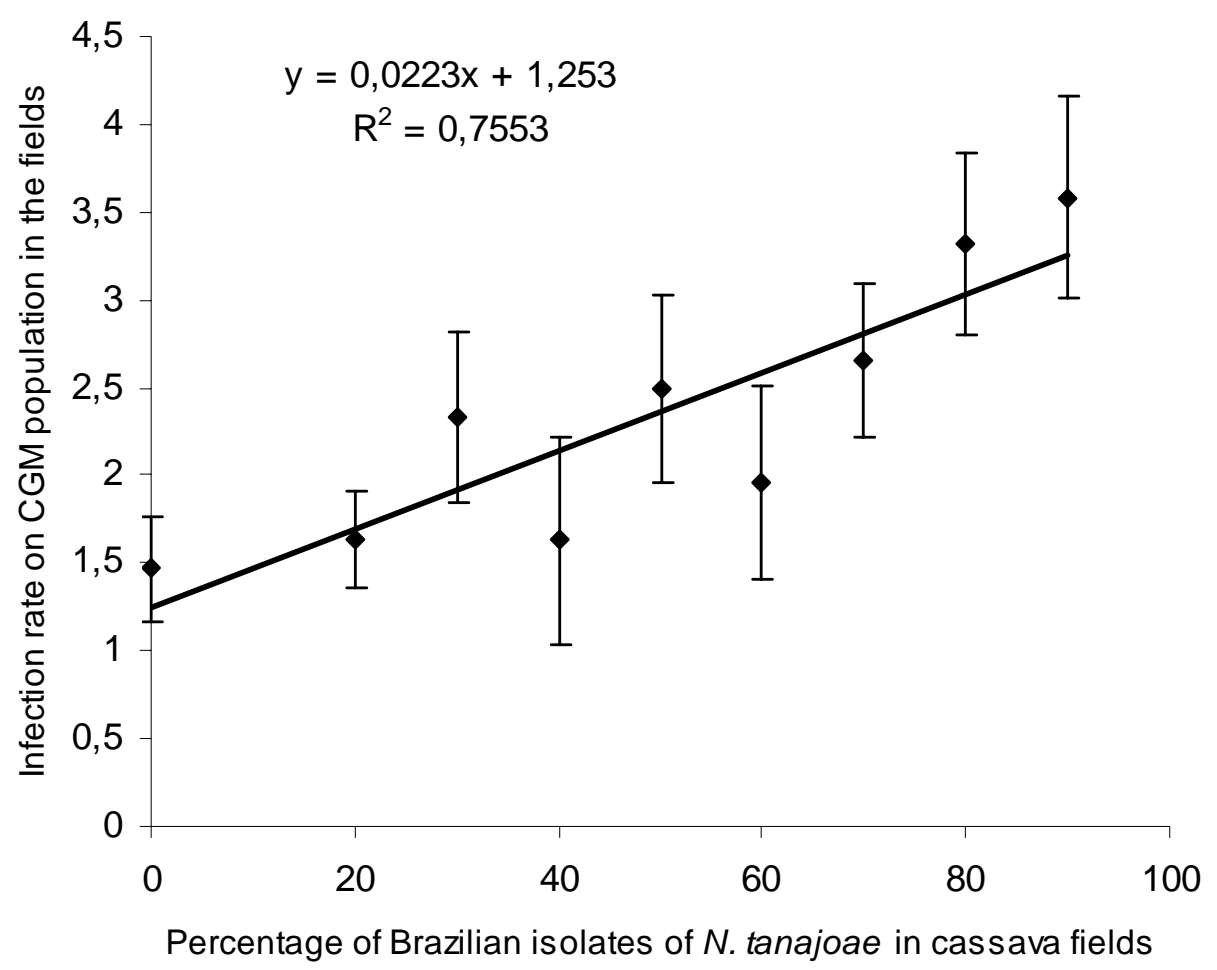

Figure 3. Infection rate of cassava green mite populations with $N$. tanajoae in cassava fields in Benin as related to the prevalence of Brazilian isolates of the entomopathogenic fungus. 
Pathogenicity and host specificity of Brazilian and African isolates of the acaropathogenic fungus Neozygites tanajoae to mite species associated with cassava Bonaventure Vidjannagni Agboton ${ }^{凶 1,2}$; Rachid Hanna ${ }^{2}$; Fabien Charles Cossi Hountondji ${ }^{2}$; Andreas von Tiedemann ${ }^{1}$ ${ }^{1}$ University of Göttingen, Department of Crop Sciences, Division of Plant Pathology and Plant Protection. Grisebachstr. 6 D- 37077 Göttingen, Germany

${ }^{2}$ International Institute of Tropical Agriculture, 08 BP 0932, Cotonou, Republic of Benin

\section{Journal of Applied Entomology (2009, submitted)}

Corresponding author: Bonaventure V. Agboton; email: bogboton@yahoo.fr

Abstract - Neozygites tanajoae is a host-specific acaropathogen introduced in the late 1990s from Brazil into cassava fields in West Africa for biocontrol of the cassava green mite (Mononychellus tanajoa). Local African isolates of Neozygites tanajoae are morphologically similar to introduced Brazilian strains but the two origins can be distinguished by diagnostic PCR. In this study suitable bioassays were established in order to explore whether differential traits in acaropathogenic performance and host specificity exist between Brazilian and African isolates. Biocontrol performance and host specificity of two Brazilian and two African isolates of $N$. tanajoae were compared on leaf discs in vivo or on whole cassava plants in the greenhouse by exposing adult female mites to inoculum delivered from $N$. tanajoae infested mite mummies. The results show that all four $N$. tanajoae isolates significantly reduced the population of M. tanajoa, both on leaf discs and on whole plants. However, on leaf discs the Brazilian isolate collected directly from Alto Alegre in Brazil had a significantly stronger biocontrol efficacy on M. tanajoa than the Brazilian isolate collected about nine years post release from a field in Adjohoun (Benin). The two African isolates performed less effectively on a level similar to the African-Brazilian isolate. On whole cassava plants, the four fungal isolates did not show any significant differences in incidence of M. tanajoa infection. The pathogenicity assays run on leaf discs against a collection of mite species typically associated with cassava plants in Africa, Typhlodromalus aripo, Euseius fustis, Tetranychus urticae and Oligonychus gossypii, demonstrated that the tested African and Brazilian isolates of $N$. tanajoae had similar host specificity for M. tanajoa. In conclusion, the bioassays applied in vitro and on whole cassava plants were suitable to assess the biocontrol potential and host range of $N$. tanajoae, however, these methods can not replace molecular techniques for differentiation among different origins of this entomopathogenic fungus.

Keywords: Host specificity, Neozygites tanajoae, Mononychellus tanajoa, Typhlodromalus aripo, Euseius fustis, Tetranychus urticae, Oligonychus gossypii, Cassava. 


\section{Introduction}

Neozygites tanajoae Delalibera Jr., Humber \& Hajek (Zygomycetes: Entomophthorales), previously known as $N$. floridana and renamed by Delalibera et al. (2004), is a pathogen of Mononychellus tanajoa (Bondar) (Acari: Tetranychidae) (Delalibera Jr. et al., 1992, 2000, 2002). It infects the mite through body contact and emission of a germ tube that penetrates the cuticle of the mite and develops into hyphal bodies, which multiply through binary division and progressively fill the haemocoel of mites (Hountondji, 2008). Infected mites can still move the first and the second day, and may thus help in the dissemination of the pathogen. They die within $3-5$ days at ca. $28^{\circ} \mathrm{C}$ (Oduor et al. 1995). Freshly dead infected mites dry out and become mummified (hence called 'mummies') within a few hours, after which they sporulate under favorable conditions. Sporulation starts with the process of conidiation which results in ejection of non-infective spores (conidia) from the mummies and ends with development of conidia into infective spores (capilliconidia). Production and distribution of haloes of spores and host density are therefore important factors of the transmissibility of $N$. tanajoae. Occurrence of $N$. tanajoae is poorly investigated due to geographically limited research on this acaropathogen. Neozygites tanajoae was first discovered as a cause of infection in M. tanajoa populations in South America, where it showed high prevalence in Columbia and particularly in Northeastern Brazil (Delalibera Jr. et al. 1992; Alvarez et al. 1993). In Africa, however, lower prevalences have generally been observed with especially low infection levels in Benin before the acaropathogen was field released in 1999 (Yaninek et al. 1996; Dara et al. 2001; Hountondji, 2008). The epizootic potential of Brazilian isolates of $N$. tanajoae has led research at International Institute of Tropical Agriculture (IITA) to consider introducing Brazilian isolates against CGM. Therefore, Brazilian isolates have been experimentally introduced to Benin, West Africa in 1998 and 1999 for the control of CGM (Hountondji et al., 2002). Precise discrimination among the closely related N. tanajoae isolates from Brazil and Africa was not possible using classical taxonomic criteria (Delalibera Jr., 2008). Also, conventional methods based on epizootiological and phenotypical diagnostics (e.g. Lee et al. 1993; Bonants et al. 1997; Brasier et al. 1999; Judelson and Tooley 2000) were not suitable. Molecular probes to distinguish exotic from native isolates were still not available at that time, making it impossible to monitor the success of introductions of exotic isolates in regions where endemic isolates of the pathogen already existed. Samples of indigenous isolates collected before the releases as well as isolates from Brazil were used in molecular characterization of the pathogen. The availability of in vitro culturing techniques for $N$. tanajoae has greatly facilitated studies aiming at developing molecular probes for the 
specific detection of isolates of the fungus (Delalibera Jr. et al., 2003). Polymerase chain reaction (PCR)-based techniques are now widely used for the detection of plant pathogens (Gachon et al. 2004; Lievens et al. 2005; McCartney et al. 2003) as well as mycelia as source materials (Tigano et al. 2006; Baek et al. 1998; Peres et al. 2006). Recently, specific primers have been designed for the detection of indigenous and exotic isolates of $N$. tanajoae (Delalibera Jr., 2008; Delalibera et al. unpublished data) and successfully applied on field samples for the PCR based detection and differentiation of Brazilian and African isolates of the fungus (Agboton et al., 2008). These primers have been validated using samples collected from several states of Brazil and from African countries where the Brazilian isolates had never been released (Agboton et al., 2008). As a result of the monitoring study, Brazilian isolates were found to be prevalent in the former release zones, suggesting that they exhibit a stronger fitness and biocontrol potential in the field than the local strains. In order to confirm this previous observation by searching to separate African isolates from Brazilian one's, the need for alternative technique still exists. Among the possible methods, attention was turned to the biocontrol potential assay and host ranges comparison of Brazilian and African isolates of $N$. tanajoae. Whereas many studies have concluded on the specificity of the Brazilian isolates of $N$. tanajoae to CGM (Moraes and Delalibera, 1992; Hountondji et al., 2002; Delalibera and Hajek, 2004), little was known about differences in the performance of African and Brazilian isolates of $N$. tanajoae on CGM. It was also not known if the host range of the African isolates of $N$. tanajoae in Africa will differ from that of the Brazilian isolates.

In this article we have compared indigenous and exotic isolates of $N$. tanajoae on the basis of their biocontrol performance and host specificity in order to discriminate between them. For that we compared the performance of two Brazilian isolates to that of two African isolates, on leaves discs and on whole cassava plants application. In addition we tested their host range within main mite species commonly found on cassava plants in Africa.

\section{Materials and Methods}

\section{Fungal isolates}

Two African and two Brazilian isolates of $N$. tanajoae were used in experiments. One Brazilian isolate was collected directly in Brazil (Brazil-Brazil isolate), while the second was sampled from fields in Adjohoun, Benin, West Africa (Brazil-Benin isolate) about nine years post release. The two Africans isolates were collected from fields in Tanzania and Benin prior to the release of exotic isolates of $N$. tanajoae. The host range was assessed using those 
Brazilian and African isolates of $N$. tanajoae against two predatory mites (Typhlodromalus aripo and Euseius fustis) and three herbivores (Mononychellus tanajoa, Tetranychus urticae, Oligonychus gossypii) commonly found on cassava. The identity and geographic origin of the fungal isolates were confirmed with specific PCR as described previously (Agboton et al., 2008). The list of isolates is presented in Table 1. Samples from each strain were stored as mummified mites (so-called mummies) at $-10^{\circ} \mathrm{C}$ in low relative humidity $(20 \%)$ in sealed plastic vials filled with cotton wool and silica gel on the bottom.

\section{In vivo cultivation of fungal isolates}

Isolates were propagated and sub-cultured in vivo on live cassava green mites (CGM; Mononychellus tanajoa) as described previously (Delalibera Jr., 2002; Agboton et al., 2008). For the multiplication of each stock of isolates used in this study, single mummies were incubated on cassava leaf discs $(1.5 \mathrm{~cm}$ in diameter $)$ placed on moist cotton wool on the bottom of a large tightly closed plastic box $(190 \times 150$ x $50 \mathrm{~mm})$. Plastic boxes were kept in a climate chamber for $24 \mathrm{~h}$ at $19 \pm 1^{\circ} \mathrm{C}, 95 \pm 5 \% \mathrm{RH}$ and $12 \mathrm{~h}: 12 \mathrm{~h}$ (light:dark) photoperiod following Oduor et al. (1996). At the end of this period, leaf discs were checked under a compound microscope and those found with capilliconidia (infective $N$. tanajoae spores) spread over about two-third of the leaf disc surface were retained for exposure to live mites ( $M$ tanajoa). Twenty healthy adult females of $M$. tanajoa with similar body size were placed per leaf disc and exposed to capilliconidia inside 150-mm diameter Petri dishes containing moist cotton wool. After exposure of the mites, the leaf discs were put to a source of light for about $30 \mathrm{~min}$ in order to stimulate the mobility of mites and get them contaminated. Then dishes were incubated at $28^{\circ} \mathrm{C}$ under a $12 \mathrm{~h}: 12 \mathrm{~h}$ light:dark regime for $24 \mathrm{~h}$ to allow infection to establish. Infected mites died within 4 to 7 days and resulting mummies were systematically collected, labeled and stored in a freezer at $-10^{\circ} \mathrm{C}$ for short-term storage or at $-20^{\circ} \mathrm{C}$ for longterm storage depending on when they were to be used in subsequent experiments. These experimental conditions resulted in a 60 to $70 \%$ infection rate similar to previous reports (Dara et al., 1998; Hountondji et al., 2002).

CGM used in the experiments were collected from cassava fields in south-west Benin free of $N$. tanajoae and reared in cohorts from eggs (the mite stage not susceptible to N. tanajoae) to adults for one generation. Emerging adults were transferred to 2-3 week-old potted cassava plants placed in small, fine-mesh cages in a greenhouse for mass rearing. Weekly, sixty live mites were mounted in $0.1 \%$ cotton blue dissolved in lactophenol and checked under a compound microscope to ensure the mites were uninfected and healthy. Using this protocol, a 
large number of mummies carrying inoculum of the particular entomopathogenic fungal isolates were produced and maintained for the biocontrol experiments and host range studies.

\section{Bioassay on leaf discs}

The two Brazilian and African isolates of $N$. tanajoae (see table1) were tested on CGM for their pathogenicity. The assay consisted of placing a single mummified mite of a particular fungal isolate in the center of a cassava leaf disc $(1.7 \mathrm{~cm}$ diameter) on a sponge bed soaked with water in a 9-cm Petri dish. The dishes were incubated as mentioned above to allow the mummies to sporulate. The sporulation was checked by placing the leaf disc on a slide and searching for capilliconidia under a compound microscope at 100x magnification. Leaf discs with high densities of capilliconidia were then selected and used for mite exposure. Twenty young adult females were transferred to the edges of each leaf disc using a single hair paintbrush. Petri dishes were incubated at $70 \pm 10 \% \mathrm{RH}, 12: 12 \mathrm{~h}$ light:dark, and $27 \pm 1^{\circ} \mathrm{C}$. For the first 3 days, the plates were kept at $100 \% \mathrm{RH}$ during the dark phase to induce further conidiogenesis and infection. During the following 3 days, the mites were transferred to fresh 2-cm cassava leaf discs. Dead mites and mummies were recorded daily for 8 days. All dead mites except for the mummified ones were stained with lactophenol/cotton blue and mounted under the phase contrast microscope at 400x in order to identify hyphal bodies which indicate infection with $N$. tanajoae. Mortality was determined from the number of dead infected mites, and the number of mummies was used to quantify the mummification rate of each isolate.

\section{Efficacy of isolates on cassava plants}

The performance of two Brazilians and two Africans isolates of $N$. tanajoae was compared on potted mite infested cassava plants. The study was conducted from March to June 2007 at the Benin station of the IITA. The experiments were carried out in a greenhouse with 15 wooden cages $(100 \times 100 \times 120 \mathrm{~cm}$, length $\times$ width $\times$ height $)$ fitted each with a transparent fine-mesh cover. The cages were arranged in a $3 \times 5$ cages design, thus each cage representing one treatment and each group of cages one replicate. Each cage contained one pot with 6 cassava plants ( $c a .18$ days old) that were infested by pinning two cassava leaf discs ( $2 \mathrm{~cm}$ diameter) with 25 adult uninfected female mites on the first expanded leaf of each plant. Ten days later, plants were inoculated with $N$. tanajoae ( $c a .17$ infected mites per disc) to the first expanded leaf of each infested potted cassava plant. Each treatment consisted in the application of a particular isolate of $N$. tanajoae. A total of five treatments were applied and repeated three times simultaneously under the same greenhouse conditions. The treatments were as follows: 
(1) Adjohoun1, (2) Alto-Alegre, (3) Coton, (4) T8 and (5) control (untreated). Mite infection was determined on the first fully expanded leaves (top leaf). The follow-up evaluations were done each week on one cassava plant per pot and cage, with each plant being used only once.

\section{Host specificity of isolates}

The method used in this study was similar to that described above. Mites were exposed to capilliconidia of each isolate of $N$. tanajoae and the infection was recorded. All strains listed in Table 1 were tested against two phytoseiid mite species, Typhlodromalus aripo and Euseius fustis, and two tetranychid mite species, Tetranychus urticae, Oligonychus gossypii. Mononychellus tanajoa was used as control. From each mite species, 8 leaf discs with 10 mites each were used for each isolate. In the case of phytoseiid mites, maize pollen was provided to feed them during the time of the experiment, while T. urticae, O. gossypii and $M$. tanajoa were fed directly on cassava leaf discs. After 2 to 3 days, leaf discs were renewed in order to provide fresh food to the herbivorous mites. The experiments were conducted in the laboratory at $25.5 \pm 3.5^{\circ} \mathrm{C}, 70 \% \mathrm{RH}$ and $12: 12 \mathrm{~h}$ light:dark regime. The trial was monitored for 8 days and any infection by the fungus was recorded. The dead mites were mounted in Amman's lactophenol-cotton blue (1\%) and examined under a compound microscope for the presence of germinated and non-germinated capilliconidia on their body. At the end of the experiment, remaining live mites were mounted in lactophenol-cotton blue and examined for the presence of hyphal bodies.

\section{Statistical analyses}

Average numbers of mites and of percent infection were obtained using PROC MEANS of SAS software (SAS, Institute 2007). To compare the isolates based on their prevalence in the mite populations, proportions of infected mites were normalized by arcsine-transformation. For the individual level experiment, the treatment effects on CGM densities were compared with ANOVA (PROC GLM, SAS Institute 2007) stratified by sampling date. Amongtreatment (strains) differences were compared with Student-Newman-Keuls (SNK) multiple range test, only where ANOVAs showed a significant treatment effect $(P<0.05)$. For the whole cassava plants experiment, a Mixed Model ANOVA (Proc Mixed, SAS Institute, 2007) with repeated statement (Littell et al., 2000) was used to determine the effect of treatment (i.e., isolate) and date of sampling on changes in population size of CGM. In the Mixed Model, isolate treatments and dates were the fixed effect factors, while plants (nested per isolate treatment) were the random effect factor, and plot (i.e. a group of plants with the same 
isolate treated) was the subject (repeated) factor. Treatment effects on CGM were compared pair-wise using pre-planned orthogonal contrasts.

\section{Results}

\section{Effect of different isolates on cassava green mite in the leaf disc assay}

All isolates caused some degree of infection to cassava green mites. Differences in mortality among isolates were obvious from the third day up to the sixth day after incubation, when mite mortality became stable (Figure 1). The final cumulative mean number of infected CGM by the Brazil-Brazil isolate was greater than $80 \%$ while those induced by the Tanzania isolate, Brazil-Benin isolate and Benin isolate were 61.3\%, 61.3\% and 62.3\%, respectively (Figure 1). Those three latter values were not statistically different among each other $(\mathrm{P}>0.05)$. From day 4 to 7, the cumulative mean number of CGM infected by the Benin isolate was higher than that observed with the Brazil-Benin isolate or Tanzania isolate (Figure 1). From 4 to 7 days after inoculation, the GLM ANOVA analysis showed a significant difference $(\mathrm{P}<0.05)$ between Brazil-Brazil and Tanzania, Brazil-Benin and Benin isolates, but no significant differences between the three latter isolates (Table 2, Figure 1). The Brazil-Brazil isolate produced more mummies (67.5\%) than the second Brazilian isolate (Brazil-Benin; 47.5\%) collected from Benin and also than the two African isolates Tanzania (45.0\%) and Benin $(43.8 \%)$.

\section{Impact of different isolates on potted infested cassava plants}

Thirty-eight days after infesting the plants, mite population decreased considerably in the control treatment and for that reason effects of the different treatments were analyzed from the first to the third week, representing 17, 24 and 31 days after plant infestation with CGM, corresponding to 7,14 and 21 days after fungus application (Figure 2a). During that period, all isolates caused some degree of infection to cassava green mites. After the second week following inoculation, the peak mite population density on the control plants was much higher (268.0 live mites per plant) than on plants treated with Brazil-Brazil, Brazil-Benin, Benin and Tanzania isolates resulting in an average of 82.0, 103.3, 128.3 and 139.7 live mites per plant, respectively. Although the mean counts of CGM strongly differed, statistical analyses using the mixed model procedure with repeated measures showed no significant differences among the different strains inoculated $(\mathrm{df}=4, F=2.25, P=0.0880)$. From the $1^{\text {st }}$ to the $3^{\text {rd }}$ week the cumulative proportion of infected mites increased on inoculated plants while no infection was 
observed in the non-inoculated plants (Figure 2b). The highest prevalence of the fungus was associated with Brazilian isolates with $25 \%$ for the Brazil-Brazil isolate and $20 \%$ for the Brazil-Benin isolate, while the two African isolates (Tanzania and Benin) reached hardly 13\% infection rates (Figure $2 b$ ).

\section{Host specificity of Brazilian and African isolates of N. tanajoae}

None of the alternative hosts tested besides CGM were found susceptible to Brazilian or African isolates of $N$. tanajoae. However, in the positive controls 55.6, 35.7, 28.8 and 42.2\% of CGM were infected with Brazil-Brazil, Brazil-Benin, Tanzania and Benin isolates, respectively. Observations made under the phase-contrast microscope showed no infection of the phytoseiid mites T. aripo and E. fustis. Similarly, no infected O. gossypii and T. urticae mites were observed with any of the fungal isolates applied.

\section{Discussion}

The present results revealed an effective suppression of cassava green mite populations by both Brazilian and the African isolates of $N$. tanajoae on cassava leaf discs and on whole cassava plants. However, the Brazilian strain collected directly from Alto-Alegre in Brazil (Brazil-Brazil isolate) showed the highest incidence on CGM in the bioassay on leaf disc compared to the three other isolates (Brazil-Benin, Tanzania and Benin) that were similar with regards to their entomopathogenic potential. In fact, the Brazil-Benin isolate collected from a post-release field in Benin was not different from the local African isolates although it has been identified as a Brazilian isolate by using PCR. This is in accordance with previous reports, where the Brazilian isolates in general caused the highest levels of mortality in CGM populations (Delalibera and Hajek, 2004; Hountondji et al. 2007, Delalibera Jr., 2008; Hountondji, 2008; Agboton et al. submitted). Interestingly, the Brazilian isolate (Adjohoun1, Brazil-Benin isolate) collected from a post-release field in Benin (West-Africa) induced a lower level of mortality similar to the African isolates in the laboratory bioassay. In fact, Adjohoun1 was collected in its new environment (post-release field) where it spent about nine years and was compared with an original isolate from Brazil (Alto Alegre, Brazil-Brazil isolate). Both isolates have been identified by specific PCR primers as originating from Brazil. Whether the lower efficacy of Brazil-Benin compared to the original isolate (BrazilBrazil) can be explained by abiotic effects from its new environment or by natural variability, is difficult to determine. Although the work of Delalibera et al. (2004) revealed a similar level of virulence of African and Brazilian isolates at the individual mite level (leaf disc trial), 
confirming our results with the Brazil-Benin isolate compared the African isolates, there was a significant difference between Brazil-Brazil and Brazil-Benin isolates with regards to their impact on CGM. Although, the Brazilian isolate collected from post release field in Benin showed a difference compared to Brazil-Brazil isolate, there were not different to African isolates, which confirm the complexity of entomopathogenic fungus $N$. tanajoae to be separated by bioassays evaluation. Previous virulence studies in the laboratory also failed to reveal significant differences between Brazilian isolates and the African isolates (Hountondji, 2008). This finding was corroborated by our results on whole cassava plants that were not able to show significant differences between African and Brazilian isolates although the highest level of fungal infection was observed with the Brazilian isolate. Other studies conducted by Delalibera et al. (2004) with 23 isolates including the two Brazilian isolates and one of the African isolates found that most isolates were highly virulent causing more than 90\% infection. A similar investigation by Delalibera and Hajek (2004) using one African isolate (collected from Benin) and one Brazilian isolate (collected from Brazil) tested against CGM from Benin at different levels of inoculum showed no differences in virulence. All those previous finding demonstrate the difficulties in differentiating indigenous and exotic isolates of $N$. tanajoae on the basis of their biocontrol performance and host specificity. Therefore, bioassays comparing important attributes of the pathogen can be used first to eliminate the less appropriate isolates (Delalibera Jr., 2008), but not to differentiate isolates.

Host range is an important characteristic in the selection of biocontrol candidates (Hountondji, 2008). The present results showed that Brazilian and African isolates of $N$. tanajoae were similar in their host range as all failed to infect any of the non-target mite species tested. This confirms earlier observations that Neozygites species are in general hostspecific and do not affect beneficial organisms (Moraes and Delalibera, 1992; Alvarez et al., 1993; Hountondji et al., 1995; Yaninek et al., 1996; Hajek et al., 2001). Similarly, N. tanajoae has been demonstrated to be highly specific to CGM while not being known so far to infect any other host (Moraes and Delalibera, 1992; Hountondji et al., 2002; Delalibera et al., 2004). Our results therefore corroborate the previous findings and add that this is similarly true for isolates both with Brazilian and African origin. Thus, host range is not an appropriate characteristic to differentiate the origin of $N$. tanajoae isolates from Africa or Brazil.

Overall, this study attempted to find characteristics in pathogenicity and host range of Brazilian and African isolates in order to separate them according to their geographic origin. This could have added options for alternative techniques of differentiating $N$. tanajoae isolates and support or partly replace molecular genetic differentiation. However, the present 
work has not verified these expectations, which is in line with previously found diagnostic limitations (Lee et al. 1993; Bonants et al. 1997; Brasier et al. 1999; Judelson and Tooley. 2000), and emphasizes the requirement of molecular genetic tools for the differentiation of $N$. tanajoae isolates as has been recently demonstrated (Agboton et al., 2008). In addition, this work provided some suitable in vivo methods to test the biocontrol potential and host specificity of $N$. tanajoae isolates under controlled conditions, on an individual and population level. A further important finding of this study is that there is no direct adverse impact by $N$. tanajoae on other beneficial mite species prevalent in the cassava agroecosystem. This is particularly important for the beneficial phytoseiid mite Typhlodromalus aripo, an important predator of M. tanajoa on cassava in Africa and suggests follow-up investigations on potential synergistic interactions of both natural enemies (T. aripo and N. tanajoae) of CGM in the same habitat.

\section{Acknowledgments}

We are grateful to the Deutscher Akademischer Austauschdienst (DAAD), the International Institute of Tropical Agriculture (IITA) through a field work grant from the International Fund for Agricultural Development (IFAD), and the University of Göttingen in Germany for supporting this research. We thank Italo Delalibera, Alexis Onzo, Muaka Toko, Ignance Zannou, Désiré Gnanvossou and Birger Koopmann for constructive comments on an earlier version of this manuscript. We are also grateful to Sam Korie for providing assistance on the statistical analysis of the data and to Honoré Dossounon and Kevin Yenou for their technical assistance.

\section{Literature Cited}

Agboton VB, Delalibera JrI, Hanna R, von Tiedemann A, 2008. Molecular detection and differentiation of Brazilian and African strains of the entomopathogen Neozygites tanajoae (Entomophthorales: Neozygitaceae) with PCR using specific primers. Biocontrol Sci. Tech. (in press).

Alvarez Afanador JM, Acosta A, Bellotti AC, Braun AR, 1993. Pathogenicity studies of a fungus associated to the cassava (Manihot esculenta Crantz) pest Mononychellus tanajoa (Bondar). Rev. Colomb. Entomol. 19, 10-20. 
Baek Seung-Cheol MD, Chae Hee-Jae MD, Dong Houh MD, Byun Dae-Gyoo MD, Cho Baik-Kee MD, 1998. Detection and differentiation of causative fungi of onychomycosis using PCR amplification and restriction enzyme analysis. Int. J. Dermatol. 37, 682-686.

Bonants P, Hagenaar-de Weerdt M, van Gent-Pelzer M, Lacourt I, Cooke D, Duncan J, 1997. Detection and identification of Phytophthora fragariae Hickman by the polymerase chain reaction. Eur J Plant Pathol 103, 345-355.

Brasier CM, Cooke DEL, Duncan JM, 1999. Origin of a new Phytophtora pathogen through interspecific hybridization. Proc Natl Acad Sci USA 96, 5878-5883.

Dara SK, Lomer CJ, Hountondji FCC, Yaninek JS, 1998. Fungal pathogens of mites on cassava: Field and laboratory studies. VII th International Colloquium on Invertebrate Pathology and Microbial Control (abstract), Sapporo, Japan.

Dara SK, Lomer CJ, Hountondji FCC, Yaninek JS, 2001. Seasonal incidence of two fungal pathogens Neozygites floridana (Zygomycotina: Zygomycetes) and Hirsutella thompsonii (Deuteromycotina: Hyphomycetes), in mite populations on cassava in Benin. In: Akoroda, M. O., and Ngeve, J. M. (Eds.), Root crops in the $21^{\text {st }}$ century. Proceedings of $7^{\text {th }}$ Triennial Symposium of the International Society for Tropical Root Crops-Africa Branch, October 11-17, 1998, Cotonou, Benin, pp. 503-507.

Delalibera JrI, Sosa Gomez DR, de Moraes GJ, Alencar JA, Farias AW, 1992. Infection of Mononychellus tanajoa (Acari: Tetranychidae) by the fungus Neozygites sp. (Entomophthorales) in northeastern Brazil. Florida. Entomol. 75, 145-147.

Delalibera JrI, de Moraes GJ, Lapointe SL, da Silva CAD, Tamai MA, 2000. Temporal variability and progression of Neozygites sp.(Zygomycetes: Entomophthorales) in populations of Mononychellus tanajoa (Bondar) (Acari: Tetranychidae). Ann. Soc. Entomol. Brasil 29, 523-535.

Delalibera JrI, 2002. Investigations towards implementation of Neozygites tanajoae sp. Nov. as a classical biological control agent against the cassava green mite in Africa. PhD. Thesis, Cornell University, Ithaca, New York, 141 pp.

Delalibera JrI, Hajek AE, Humber RA, 2003. Use of cell culture media for cultivation of the mite pathogenic fungi Neozygites tanajoae and Neozygites floridana. J. Invertebr. Pathol. 84, 119-127.

Delalibera JrI, Hajek AE, Humber RA, 2004. Neozygites tanajoae sp. Nov., a pathogen of the cassava green mite. Mycologia 96, 1002-1009. 
Delalibera JrI and Hajek AE, 2004. Pathogenicity and specificity of Neozygites tanajoae and Neozygites floridana (Zygomycetes: Entomophthorales) isolates pathogenic to the Cassava Green Mite. Biological Control 30, 608-616

Delalibera JrI, 2008. Biological control of the cassava green mite in Africa with Brazilian isolates of the fungal pathogen Neozygites tanajoae. In: Hajek AE, Glare TR, O Callaghan M. (Org.). Use of microbes for control and eradication of invasive arthropods. New York: Springer, 2008, v. 6, p. 259-269.

Gachon C, Mingam A, Charrier B, 2004. Real-time PCR: What relevance to plant studies? J. Exp. Bot. 55, 1445-1454.

Hajek AE, Wraight SP, Vandenberg JD, 2001. Control of Arthropods using Pathogenic fungi, pp. 309-347. In (S.B. Pointing \& K.D. Hyde, Eds.) Bio-Exploitation of Fungi. Fungal Diversity Press, Hong Kong.

Hountondji FCC, De Nardo EAB, Tamai MA, 1995. Nào susceptibilidade de abelhas à infeccào pelo fungo Neozygites sp. Agente de control do ácaro verde da mandioca. In: Anaís do $15^{\circ}$ Congresso de Entomologia, 12-17 Marco 1995, Caxambú-MG, Brazil.

Hountondji FCC, Yaninek JS, de Moraes GJ, Oduor GI, 2002. Host specificity of the cassava green mite pathogen Neozygites floridana. Biocontrol 47, 61-66.

Hountondji FCC, Hanna R, Cherry AJ, Sabelis MW, Agboton VB, Korie S, 2007. Scaling up tests on virulence of the cassava green mite fungal pathogen Neozygites tanajoae (Entomophthorales: Neozygitaceae) under controlled conditions: first observations at the population level. Exp. Appl. Acarol 41, 153-168.

Hountondji FCC, 2008. Lessons from interaction within the cassava green mite fungal pathogen Neozygites tanajoae system and prospects for microbial control using Entomophthorales. Exp. Appl. Acarol 46, 195-210.

Judelson HS, Tooley PW, 2000. Enhanced polymerase chain reaction methods for detecting and quantifying Phytophthora infestans in plants. Phytopathol. 90, 1112-1119.

Lee SB, White TJ, Taylor JW, 1993. Detection of Phytophthora species by oligonucleotide hybridization to amplified ribosomal DNA spacers. Phytopathol. 83, 177-181.

Lievens B, Thomma BPHJ, 2005. Recent developments in pathogen detection arrays: Implications for fungal plant pathogens and use in practice. Phytopathol. 95, 1374-1380.

Littell RC, Pendergast J, Natarajan R, 2000. Tutorial in biostatistics: Modelling covariance structure in the analysis of repeated measures data. Statist. Med. 19, 1793-1819.

McCartney HA, Foster SJ, Fraaije BA, Ward E, 2003. Molecular diagnostics for fungal plant pathogens. Pest Manag. Sci. 59, 129-142. 
Moraes GJ, Delalibera JrI, 1992. Specificity of a strain of Neozygites sp. (Zygomycetes: Entomophthorales) to Mononychellus tanajoa (Acari: Tetranychidae). Exp. Appl. Acarol. 14, 89-94.

Oduor GI, de Moraes GJ, van der Geest LPS, Yaninek JS, 1996. Production and germination of primary conidia of Neozygites floridana (Zygomycetes: Entomophthorales) under constant temperatures, humidities, and photoperiods. J. Invertebr. Pathol. 68, 213-222.

Oduor GI, de Moraes GJ, Yaninek JS, van der Geest LPS, 1995. Effect of temperature, humidity and photoperiod on the mortality of Mononychellus tanajoa infected by Neozygites floridana. Exp. Appl. Acarol. 19, 571-579.

Peres NA, Harakava R, Carroll GC, Adaskaveg JE, Timmer LW, 2006. Comparison of molecular procedures for detection and identification of Guignardia citricarpa and $G$. mangiferae. Plant Dis. 91, 525-531.

SAS Institute, 2007. SAS system for Windows, Statistics. Release 6.12, version 9.1. SAS Institute Inc., Cary, NC, USA.

Tigano MS, Adams B, Maimala S, Boucias D, 2006. Genetic diversity of Hirsutella thompsonii isolates from Thailand based on AFLP analysis and partial $\beta$-tubulin gene sequences. Genet. Mol. Biol. 29 (4), 715-721.

Yaninek JS, Saizonou S, Onzo A, Zannou I, Gnanvossou D, 1996. Seasonal and habitat variability in the fungal pathogens: Neozygites cf. floridana and Hirsutella thompsonii, associated with cassava mites in Benin. Biocontrol Sci. Tech. 6, 23-33. 
Table 1. List of isolates of $N$. tanajoae used in the study

Molecular identification Identity of

Isolates

Name

Origin

Strains

$(\mathrm{NEOSSU})^{\mathbf{a}} \quad(8 \mathrm{DDC})^{\mathbf{b}}$

\begin{tabular}{llllll}
\hline Adjohoun1 & Brazil-Benin & Adjohoun, Benin & + & + & Brazilian \\
Alto-Alegre & Brazil-Brazil & Alto-Alegre, Brazil & + & + & Brazilian \\
Coton & Benin & Cotonou, Benin & + & - & African \\
T8 & Tanzania & Kayenze, Tanzania & + & - & African \\
\hline
\end{tabular}

${ }^{a}$ molecular marker specific for detecting the infected mummified mites (mummies) of $N$. tanajoae.

${ }^{\mathrm{b}}$ molecular marker specific for differentiating the Brazilian isolates of $N$. tanajoae to African ones.

Table 2. Percentage of dead mite recorded from day 4 to 7 after mites exposure to the spores of different isolates of $N$. tanajoae

\section{Least Square Means (\%)}

Days after fungal exposure

\begin{tabular}{lccccc} 
Isolates & Number & 4 & 5 & 6 & 7 \\
\cline { 3 - 6 } Alto Alegre & 1 & $42.1 \mathrm{a}^{*}$ & $51.5 \mathrm{a}$ & $63.6 \mathrm{a}$ & $65.8 \mathrm{a}$ \\
Adjohoun1 & 2 & $36.9 \mathrm{ab}$ & $47.1 \mathrm{ab}$ & $51.6 \mathrm{~b}$ & $52.3 \mathrm{~b}$ \\
Coton & 3 & $33.0 \mathrm{~b}$ & $45.7 \mathrm{~b}$ & $51.5 \mathrm{~b}$ & $51.5 \mathrm{~b}$ \\
T8 & 4 & $24.5 \mathrm{c}$ & $37.7 \mathrm{c}$ & $51.5 \mathrm{~b}$ & $51.5 \mathrm{~b}$ \\
Control & 5 & $00.0 \mathrm{~d}$ & $00.0 \mathrm{~d}$ & $00.0 \mathrm{c}$ & $00.0 \mathrm{c}$
\end{tabular}

* Values within columns followed by the same letter are not significantly different at the 5\% significance level (Student-Newman-Keuls test). 


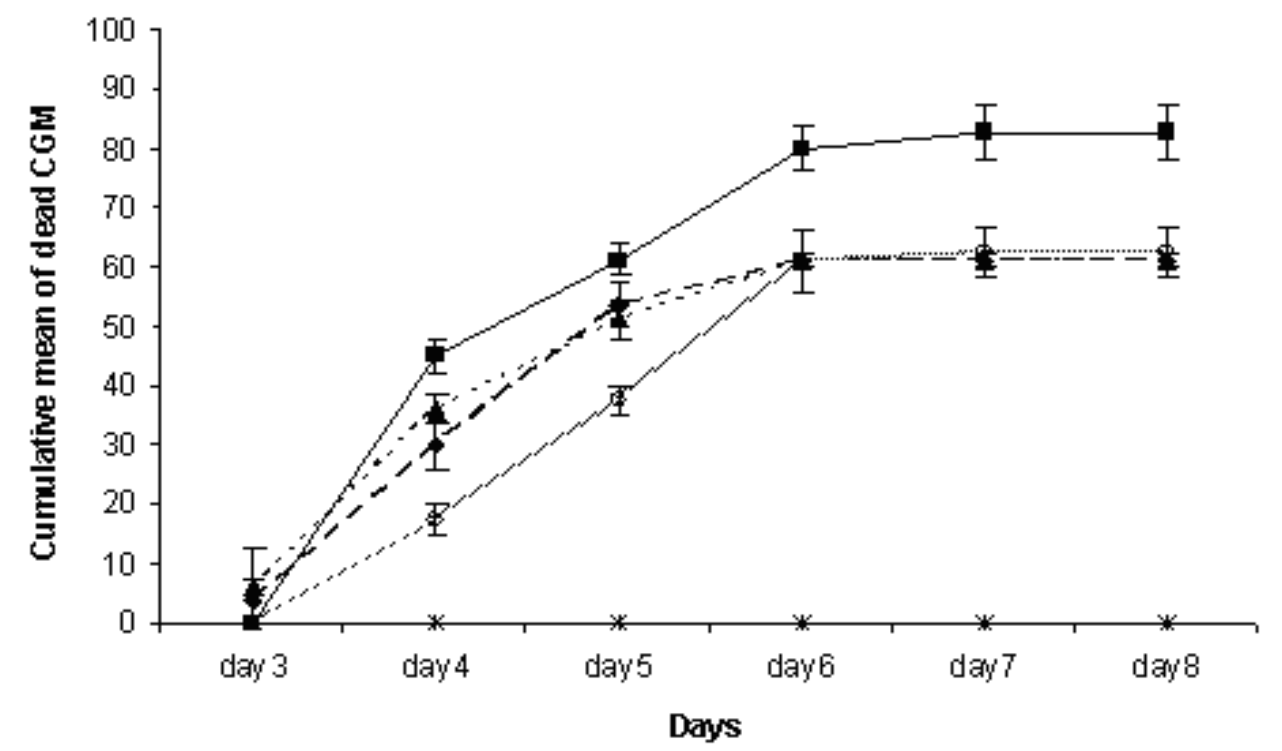

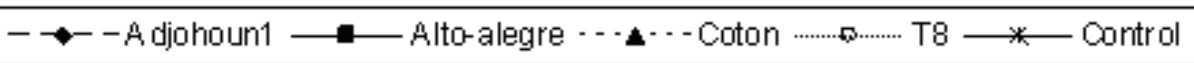

Figure 1. Mean counts ( $\pm \mathrm{SE}$ ) of dead cassava green mites killed by different strains of $N$. tanajoae (Alto Alegre, Brazilian; Adjohoun1, Brazilian-Benin; T8, Coton, African origin). 

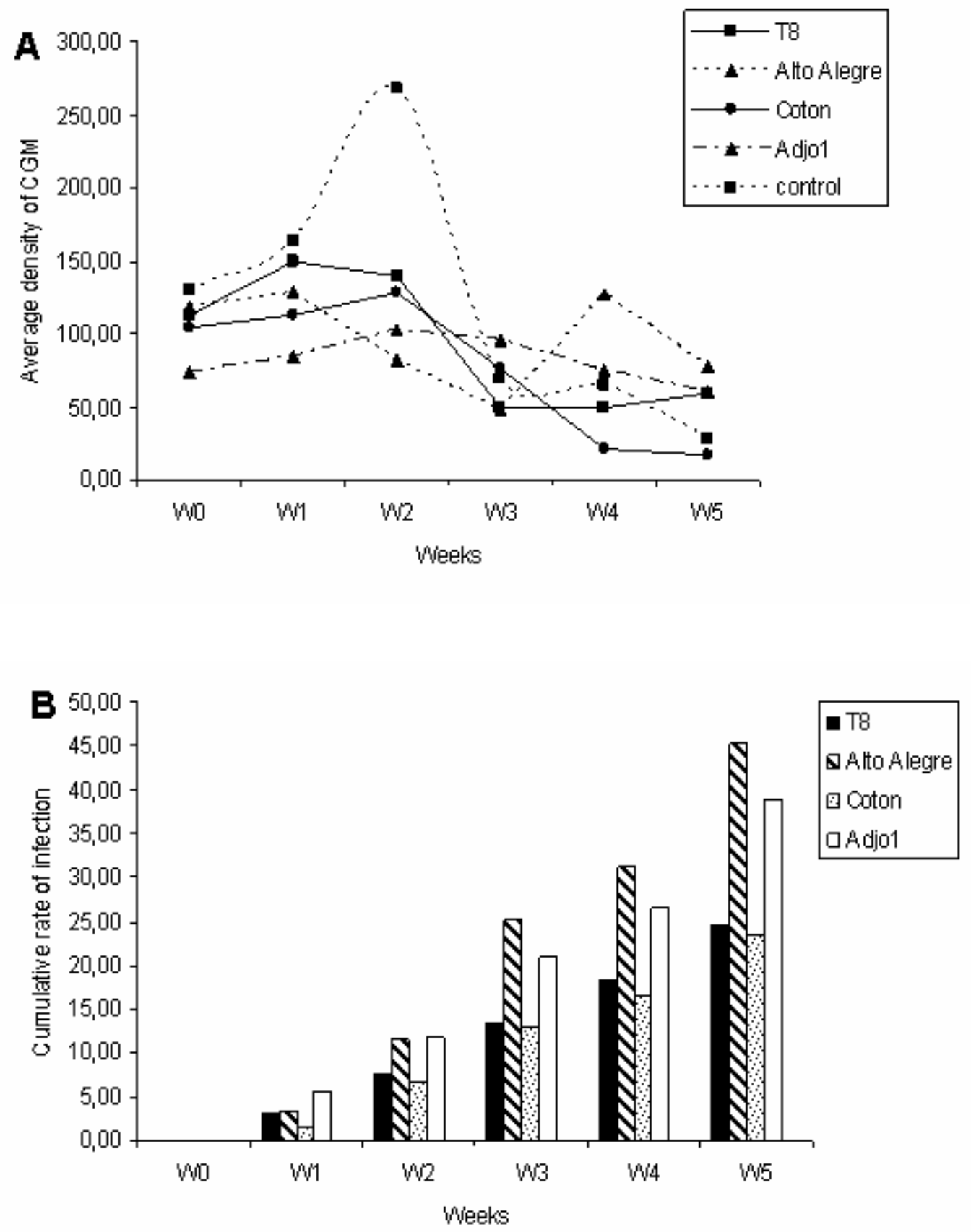

Figure 2. Average densities of cassava green mites (CGM) on cassava plants after inoculation with Brazilian (Alto Alegre), Brazilian-Benin (Adjohoun1) and African (T8, Coton) strains of N. tanajoae (A), and the cumulative percentage of CGM infected by different isolates (B). 
Interactions between the entomopathogenic fungus Neozygites tanajoae and the predatory mite Typhlodromalus aripo in the biological control of cassava green mite

\title{
(Mononychellus tanajoa)
}

\author{
Bonaventure Vidjannagni Agboton ${ }^{1,2}$. Rachid Hanna ${ }^{2}$. Alexis Onzo ${ }^{2}$. Stefan Vidal ${ }^{3}$. Andreas von Tiedemann ${ }^{1}$ \\ ${ }^{1}$ University of Göttingen, Department of Crop Sciences, Division of Plant Pathology and Crop Protection. \\ Grisebachstr. 6 D- 37077 Göttingen, Germany \\ ${ }^{2}$ International Institute of Tropical Agriculture, 08 BP 0932, Cotonou, Republic of Benin \\ ${ }^{3}$ University of Göttingen, Department of Crop Sciences, Division of Agricultural Entomology. Grisebachstr. 6 D- 37077
} Göttingen, Germany

\section{Biological Control (in preparation)}

Corresponding author: Bonaventure V. Agboton; email: bogboton@yahoo.fr

\begin{abstract}
Following the introduction of Neozygites tanajoae in Benin for control of cassava green mite (CGM, Mononychellus tanajoa) this entomopathogenic fungus co-occurs with the predatory mite Typhlodromalus aripo in cassava fields. However, studies on mutualistic or antagonistic interactions of the two biocontrol agents with regard to enhancing the biological control of CGM populations are lacking. In a series of greenhouse experiments, effects of single and combined releases of $N$. tanajoae and $T$. aripo on their respective population dynamics and on the suppression of CGM populations were evaluated. In the single species treatments, both $T$. aripo and $N$. tanajoae significantly reduced CGM densities, however, T. aripo appeared to perform superior than $N$. tanajoae. The co-application of the two natural enemy species on cassava plants reduced their respective abundance as compared to single applications, and resulted in a significantly reduced biocontrol effect on CGM density 2 weeks after treatments. Laboratory experiments conducted on feeding activity, oviposition and survival of T. aripo fed with healthy or $N$. tanajoae-infected CGM showed that $T$. aripo preferred feeding on infected CGM. Concomitantly, the oviposition and survival rates of $T$. aripo were lower when fed with infected as compared to healthy mites, thereby reducing the reproduction rate of the predatory mite. Moreover, by feeding preference on infected mites, T. aripo reduced the entomopathogenic inoculum. Both effects may explain the reduced biocontrol efficacy of the two antagonistic species when applied simultaneously. The results suggest that simultaneous releases of $T$. aripo and $N$. tanajoae in the same field may reduce the efficacy of the biological control of CGM. It may be therefore preferable to apply single agents selected according to their adaptation to the prevailing environmental conditions in the specific geographical area.
\end{abstract}

Keywords: Typhlodromalus aripo, Neozygites tanajoae, Predator-pathogen interactions, Mononychellus tanajoa, cassava. 


\section{Introduction}

The issue of introducing single or multiple natural enemy species for classical biological control has been since long a matter of debate among ecologists and biological control practitioners (Polis et al. 1989; Sih et al. 1998; Losey and Denno 1999; Gnanvossou et al. 2003; Onzo et al. 2004; Onzo et al 2005b). Several authors have argued for screening natural enemies and releasing only the most effective species (Briggs 1993; Ehler and Hall 1982). This strategy has been challenged, however, by others who found little evidence that one natural enemy species provides higher suppression than two or more natural enemy species applied together (Croft et al. 1992; Huffaker et al. 1971; Lang 2003; Riechert and Lawrence 1997). Interactions among natural enemy species can take two opposite directions with respect to their impact on the target pest populations (Losey and Denno 1999; Wekesa et al. 2007). Two predator species may act in a complementary fashion thereby increasing predation risk to the prey (Heinz and Nelson 1996; Losey and Denno 1998; Onzo et al. 2004; Riechert and Lawrence 1997). On the other hand, two predators may also interfere with each other through intra-guild predation or some other forms of interspecific interactions, thereby decreasing predation risk to the prey (Rosenheim 2001; Spiller 1986).

Natural enemies interactions are particularly relevant to classical biological control of cassava green mite (CGM), Mononychellus tanajoa (Bondar) (Acari: Tetranychidae) in Africa, as this pest mite is attacked by several natural enemies. Two of these, Typhlodromalus aripo De Leon and Amblydromalus (Typhlodromalus) manihoti Moraes (Acari: Phytoseiidae) have been introduced from Brazil, established and widely spread in African cassava fields (Yaninek et al. 1998; Gnanvossou et al. 2001; Onzo et al. 2003; Yaninek and Hanna 2003; Zannou et al. 2007). However, none of these two predatory mite species have consistently established in the arid, semi-arid, and mid-altitude areas. Furthermore, although establishment was successful, reduction of CGM populations due to the exotic phytoseiids were estimated not more than 50\% (Hanna, personal communication). Introduction of Brazilian isolates of the entomopathogenic fungus Neozygites tanajoae (Entomophthorales: Neozygitaceae) was envisaged to complement and improve the phytoseiid impact (Hountondji et al. 2002a). Neozygites tanajoae is an important natural regulator of CGM populations in northeastern Brazil (Delalibera et al. 1992, 2000, 2002). Hountondji et al. (2002b) investigated the pathogenicity of Brazilian isolates of $N$. tanajoae on several beneficial and non-target species before its introduction in Benin and observed that $N$. tanajoae is specific to CGM (Hountondji et al. 2002b; Delalibera et al. 2004; Hountondji, 2008). Particularly, these isolates are known not to infect $T$. aripo which has become the most effective exotic predator for control of CGM in Africa (Yaninek et al. 2003). Those two exotic natural enemies of GCM on cassava in Africa therefore constitute a suitable system for assessing the impact of predator-pathogen 
interactions on suppression of pest populations. Pathogens and predators may contribute to the suppression of their target pest population either as individual species or as species complexes. $T$. aripo and $N$. tanajoae are currently sharing the same cassava field agroecosystem and may be utilized in an integrated control system against CGM. However, until now no data are available on the outcome of simultaneous fungus and predatory mite applications in the same field, especially with regard to their efficacy in CGM suppression. In order to evaluate the potential biocontrol efficacy in an IPM approach to control CGM, there is an urgent need to determine the relative contribution of each natural enemy species in comparison to their interactive performance in the biological control of CGM in the short and long term.

We conducted greenhouse and laboratory experiments in order to (1) determine the impact of the interaction between $T$. aripo and $N$. tanajoae on the population density of CGM, and (2) to understand how feeding on fungus-infected mites affects the population dynamics of the predatory mite and thereby influences the biological control of CGM.

\section{Materials and methods}

\section{Studied organisms}

Adult $C G M$ females used in the experiments were obtained in a laboratory culture initiated from egg cohorts laid by an initial population collected in south-west Benin from cassava fields free of $N$. tanajoae. Adult females that emerged from these eggs were transferred to 2-3 week-old potted cassava plants placed in small, fine-mesh cages in a greenhouse for mass rearing. Every week, sixty live mites were mounted in $0.1 \%$ cotton blue dissolved in lactophenol and checked under a compound microscope for the presence or absence of fungal infections.

Adult females of T. aripo used in this study were collected from cassava fields near the town of Sè, Department of Mono, Southwestern Benin, and maintained in a laboratory at IITA-Benin Station on a diet made of all stages of CGM. The predatory mites were continuously reared on potted cassava plants in a greenhouse before being used.

Fungal isolates were preserved as N. tanajoae-infected mummified CGM referred to as 'mummies'. Mummies were collected from Alto Alegre in the state of Bahia, Brazil in 2007 and shipped to IITA-Benin, where they were maintained in the laboratory at $4^{\circ} \mathrm{C}$. The stored mummies were propagated and sub-cultured in vivo on live CGM as described previously (Delalibera, 2002; Delalibera and Hajek, 2004; Agboton et al., 2008; Delalibera, 2008). For each experiment, a new batch of mummies was produced to be used within a maximum of two weeks in order to minimize loss of viability. 


\section{Experimental set-up in the greenhouse}

The experiments were conducted on potted cassava plants inside cages in a greenhouse at the Biological Control Center for Africa, International Institute of Tropical Agriculture, located in Cotonou, Benin, from April to September 2007. The greenhouse (length $\mathrm{x}$ width $\mathrm{x}$ height $=24 \mathrm{~m} \mathrm{x}$ $8.5 \mathrm{~m} \times 5 \mathrm{~m}$ ) was equipped with a canopy of Teflon plastic and the sides covered with an amber screen of $32 \mu \mathrm{m}$ x $32 \mu \mathrm{m}$ mesh size. To prevent excessive heat build-up, windows at the opposite ends of the greenhouse were opened to allow for air circulation. Temperature inside the greenhouse ranged from 25 to $38^{\circ} \mathrm{C}$ with relative humidity varying between 44 and $94 \%$. The experiments were carried out using 12 cages $(100 \times 100 \times 120 \mathrm{~cm}$ in length $\times$ width $\times$ height $)$ fitted each with a transparent fine-mesh cover.

The cassava plants used in the experiments were obtained from farmer's fields around Lokossa in southwestern Benin. Six cassava cuttings (20 cm long) of the variety "Agric" were planted in each of 12 plastic pots ( $24 \mathrm{~cm}$ high and 20 to $26 \mathrm{~cm}$ in diameter from the base to the top). The pots were filled with ca. $12 \mathrm{~kg}$ of topsoil collected from a field under fallow for more than 4 years, where no fertilizers and pesticides have been used for at least the past 14 years. Pots with cassava plants were transferred into the cages inside the greenhouse within $48 \mathrm{~h}$ after planting and placed on iron benches. The cages (Fig. 1a) were arranged in 3 groups of 4 cages each containing one pot with six plants. Each group represented one replicate of a treatment. Treatments were assigned to each group of cages at random.

Each side of a cage was disinfected overnight with 70\% alcohol and rinsed with distilled water the next day before starting the experiment. The fine-mesh covers were also sprayed with $70 \%$ alcohol to minimize the risk of unexpected infections by a fungal isolate. At the start of the experiment (Fig 1a, 1b), the potted plants were infested with CGM by pinning two cassava leaf discs $(2 \mathrm{~cm}$ in diameter) with 25 uninfected adult female CGM on each of the first expanded leaves of each plant. Each plant was therefore infested with 50 adult female CGM. Ten days later, CGM-infested plants were assigned to each of the following four treatments: (1) release of 25 T. aripo adult females, (2) release of 25 live $N$. tanajoae-exposed CGM, (3) release of 25 T. aripo adult females plus 25 live $N$. tanajoae-exposed CGM and (4) a control that remained free of predatory mites and the fungus.

The appropriate number of predators for each plant in each treatment was placed directly on the first fully expanded leaf of each cassava plant using a camel-hair brush. The fungus was inoculated by pinning cassava leaf discs with $N$. tanajoae-infected CGM to the first fully-expanded leaf of each potted plant. The N. tanajoae-infected CGM were obtained by exposing 30 healthy female CGM from the greenhouse colonies to fresh capilliconidia produced by a sporulating mummy on a $2-\mathrm{cm}$ diameter leaf disc as described previously (Delalibera, 2002; Delalibera and Hajek, 2004; Agboton et al., 2008; Delalibera Jr., 2008; Hountondji, 2008). 
From each treatment, one whole plant was sampled per week, starting on the day when the natural enemies were added, in order to determine the initial CGM population levels. The plants were removed from the cutting, placed in a plastic bag and brought to the laboratory for counting. Eggs and active stages (larvae, nymphs and adults) of CGM, active stages of T. aripo in the apex and on all the leaves and all $N$. tanajoae-infected CGM (infected and mummified CGM) from each plant were counted in the laboratory with a binocular microscope.

\section{Laboratory investigations}

The laboratory experiment consisted of an evaluation of the oviposition and survival of T. aripo fed with healthy or N. tanajoae-infected CGM. Cohorts of 50 T. aripo gravid females (6-7 days after egg hatching) were reared for use in the experiments. The $T$. aripo gravid females were starved for $24 \mathrm{~h}$ prior to the start of the experiments. The experimental unit consisted of a cassava leaf disc (2$\mathrm{cm}$ diameter) with the abaxial surface placed up on water-saturated cotton wool in an open Petri dish (13-cm- diameter). The two treatments made were as follows: (1) one juvenile gravid female of $T$. aripo fed with 20 healthy mites per day; (2) one juvenile gravid female of $T$. aripo fed with 20 infected mites per day. Each treatment was repeated 10 times. Food supply was renewed every $24 \mathrm{~h}$ after counting the number of eggs laid in each treatment as well as the number of CGM (uninfected and infected). In each treatment, all eggs laid within $24 \mathrm{~h}$ were removed from the experimental unit before the next feeding. The predator mites were fed until they died and their life span was recorded. Because of the considerable attention needed in setting up and following up the treatments, all 10 replicates of each treatment were established in same time as described above and placed in the same experimental condition in the laboratory. All treatments were conducted simultaneously in a growth chamber at $25-27^{\circ} \mathrm{C}$ and at $70-90 \% \mathrm{RH}$ for a maximum of 17 days.

The number of CGM (healthy and infected) consumed on each cassava leaf disc by T. aripo and eggs laid were recorded every $24 \mathrm{~h}$ until the test female predator died. The daily consumption and number of eggs laid by each $T$. aripo were calculated and averaged for the ten replicates.

\section{Statistical analyses}

For statistical analyses, CGM (lives); T. aripo (lives) and Neozygites tanajoae (infected and mummified mites) were summed on a per plant basis. Average and standard errors were calculated from the log-transformed sums per plant and plotted against sampling dates. A Mixed Model ANOVA (Proc Mixed, SAS Institute, 2007) with repeated statement (Littell et al. 2000) was used to determine the effect of treatment (i.e., natural enemy release) and date of sampling on changes in population sizes of CGM, T. aripo, and N. tanajoae. In the Mixed Model, treatment, date, and interaction between treatment and date were the fixed effect factors, while replicate and plant were 
the random effect factors, and replicate nested in treatment was the subject (repeated) factor. Treatment effects on prey and predator densities were compared pair-wise using pre-planned orthogonal contrasts. All statistical analyses were carried out for CGM (actives), T. aripo (actives) and N. tanajoae (infected and mummified mites). For the two natural enemies' species treatments, proportions of $T$. aripo were calculated for each treatment, to detect if the natural enemies' combination negatively affected any of the two enemies species. Densities of $T$. aripo and $N$. tanajoae might differ according to the different treatment applied, then, their densities in the single and combined species treatments were pooled per sampling date and means were calculated. These fractions were used as expectations under the null hypothesis that the predator species did not affect each other. A regression analysis was carried out on the population of T. aripo and N. tanajoae in the combined treatment to check for the effect of the presence of both natural enemies in one ecosystem. In the laboratory investigations, ANOVA with Student-Newman-Keuls multiple range test (SAS Institute, 2007) was used to compare each diet preference by T. aripo and its oviposition related to the two food types. Using life table analysis in SAS program, the test of equality over food type was performed. The effect of treatment (i.e., type of diet given to T. aripo) on survival of T. aripo was tested using the coefficient of Wilcoxon.

\section{Results}

\section{Impact of T. aripo and N. tanajoae on CGM populations}

Densities of CGM differed significantly among treatments (Table 1) throughout the experimental observation period. In the control, CGM densities passed through three distinct phases, an increase during the first 8 days after the natural enemy release, followed by a relatively stable population growth phase between day 8 and 16, which was followed by a decline finally (Fig. 2a). In contrast, the two antagonists (T. aripo and $N$. tanajoae) substantially reduced CGM densities from the start of the experiment, as compared with the control (Fig. 2a, Table 1). However, there were significant differences in CGM abundance between the two natural enemy treatments (Fig. 2a). T. aripo alone had a significantly greater effect in reducing CGM densities as compared to the single treatment with $N$. tanajoae (Fig. 2a; Table1) and was also superior to the combined treatment (T. aripo \& $N$. tanajoae). This effect became clearly noticeable 16 days post starting the experiment. The factors involved in this interaction were further illustrated in the laboratory experiments on cassava leaf discs. 


\section{Development of T. aripo and N. tanajoae}

Densities of natural enemy species always increased soon after being released and continued to increase even after the onset of the decline in prey or host populations. However, towards the end of the experiment, antagonist densities decreased with declining CGM populations (Fig. 2b).

Throughout the experiment, population size of $T$. aripo significantly differed among treatments. Densities of $T$. aripo were significantly higher when released alone as compared to the combined application with $N$. tanajoae (Fig. 2b). Sixteen (16) days after enemy release, $T$. aripo passed from 28 to 25 lives in single treatment, but in the combined treatment T. aripo passed from 26 to 6 actives (Fig. 2b). The proportion of $N$. tanajoae infected mites, indicating the propagation and spread of the fungus, increased in both treatments ( $N$. tanajoae alone or combined with T. aripo) until 16 days post application of the antagonist. However after 8 days, the proportion of $N$. tanajoae infected mites in single treatments significantly surmounted that of the combined treatment (Fig. 2c, Table 1), reaching a peak of $51 \%$ as compared to the combined treatment which never exceeded $30 \%$ until the last sampling date (Fig. 2c).

Moreover, the high level of mite infection with $N$. tanajoae was observed with a lower density of $T$. aripo in the combined application (T. aripo with N. tanajoae).

\section{Food preferences and oviposition rates of T. aripo}

In general, T. aripo consumed both healthy and infected CGM. However, the daily consumption of CGM by T. aripo significantly differed according to the infection stage of the prey mites $(P<0.05)$. In the choice experiment $T$. aripo preferred to consume infected cassava green mites as compared to healthy ones (Fig. 3). The oviposition rate of T. aripo also significantly differed between the two mite categories consumed $(P<0.05)$. However, numbers of eggs laid by $T$. aripo were significantly lower when fed with infected cassava green mites as compared to healthy mites (Fig. 3). Also, the survival of $T$. aripo was affected by the quality of prey mites, being significantly different $(\mathrm{P}<$ $0.01 ; d f=1 ; \mathrm{P}=0.0042$ and 0.0048 for log-rank test and Wilcoxon test, respectively) with T. aripo living two days longer when subjected to a diet of healthy mites than infected mites (Fig. 4). Thus, the life span of $T$. aripo was significantly shorter on a diet of infected cassava green mite as compared to healthy mites. 


\section{Discussion}

Our experiments demonstrate that, being separately applied, T. aripo and $N$. tanajoae are able to suppress CGM populations, confirming previous observations on the biocontrol potential of $T$. aripo (Hanna et al. 2001; Onzo et al. 2003; Yaninek and Hanna 2003), or of N. tanajoae (Alvarez et al. 1993; Hajek et al. 2001; Delalibera et al. 2004; Hountondji et al. 2002a; Hountondji et al. 2007; Hountondji, 2008). Comparisons between the two neotropical natural antagonist species in single treatments showed that the suppression caused by T. aripo on CGM densities was significantly higher than that caused by $N$. tanajoae suggesting that in our experimental conditions $T$. aripo has been more effective than $N$. tanajoae in suppressing CGM populations. The superior performance of $T$. aripo is likely due to its ability to feed immediately on CGM, while $N$. tanajoae as an entomopathogen requires some time to develop an infection inside CGM before individuals start to dye from infection (Hajek et al. 2001). In fact, it is known for many entomopathogenic fungal species, that hosts are killed only after entire colonization of the arthropod (Hajek et al. 2001). However, successful transmission of pathogens from infected to healthy hosts such that epizootics can occur in the host's populations requires time and conducive environmental conditions (Hajek et al. 2001). In the greenhouse experiments, such conditions are not $100 \%$ guarantied, and this may explain why $T$. aripo has been superior to $N$. tanajoae in reducing CGM densities in our experiments.

Previous research on T. aripo (Onzo et al. 2003; Yaninek and Hanna 2003; Onzo et al. 2005a) and on N. tanajoae (Delalibera et al. 2004; Hountondji et al. 2002a; Hountondji et al. 2007) demonstrated that their biocontrol efficacy in single use is based on completely different mechanisms of CGM suppression. While the predator attacks directly the CGM by killing it, the pathogen develops an infection inside the mite, and colonizes its entire body. In this study we tested the hypothesis that the presence of both natural enemy species on the same cassava plant should result in additive or more-than-additive effects on the suppression of CGM populations. This hypothesis was further based on the different sites of impact of the two natural enemy species, as $T$. aripo inhabits the plant apex during the day and forages on upper leaves only during the night (Onzo et al. 2003), whereas N. tanajoae is found mostly on cassava leaves (Yaninek et al. 1996; Hountondji et al. 2002a). Thus, the two antagonist species occupy different niches and therefore should not compete with each other. However, our greenhouse experiments demonstrate that the cooccurrence of T. aripo and $N$. tanajoae on the same cassava plant had a less-than-additive efficacy in suppressing CGM as compared to the level of suppression achieved by T. aripo or N. tanajoae alone. As a consequence, CGM populations increased in the combined treatment (T. aripo and $N$. tanajoae) two weeks after natural enemy release which was accompanied by lower densities of the two natural enemy species. These data indicate that the two antagonist species affect each other in a 
negative way, although $N$. tanajoae is not entomopathogenic on $T$. aripo, and thus concur with previous work suggesting an indirect interspecific interaction between $T$. aripo and $N$. tanajoae (Hountondji et al. 2002b; Agboton et al. in preparation). Ariori et al. (2007) demonstrated that the consumption of pathogen-infected pest mites by predatory mites can reduce the effectiveness of the microbial control agent. This effect may be enhanced by a preference of the predator for feeding on infected hosts, thereby reducing the entomopathogenic inoculum which otherwise would be dispersed among living host mites. This purported mechanism has been confirmed in our study as in the combined treatments high $T$. aripo densities were associated with decreased $N$. tanajoae infections. This mechanism may also explain the variability observed when both enemies were released together in the same habitat, as well as the failure of the mite-pathogenic fungus $N$. tanajoae and the other predatory mite Neoseiulus idaeus to control a population of CGM in central Bahia, Brazil (Elliot et al. 2008).

Our understanding of reduced T. aripo densities in the combined treatment was further corroborated by the laboratory experiments conducted on cassava leaf discs with females of $T$. aripo fed either with CGM infected by $N$. tanajoae or healthy CGM. These data indicate that $T$. aripo consumed significantly more infected CGM than healthy ones. This may be due to the fact that infected mites are less mobile as compared to the mobility of healthy mites. This may have allowed T. aripo to feed more easily on these prey items than on fast moving healthy ones. By feeding on infected mites, T. aripo reduced the density of fungal inoculum, thereby, however, impairing its own reproduction and longevity because of the poor quality of the diet consumed. It has been reported for other entomopathogenic Hyphomycetes species, that hosts can be killed by fungus-produced toxins (Boucias and Pendland 1998). Such toxins could also be produced by N. tanajoae inside infected CGM that are consumed by $T$. aripo, resulting in reduced T. aripo densities. Therefore, when both natural enemies are applied in combination in the same habitat, they may affect their own populations thereby weakening their biological efficacy with the result of increased pest populations. Hence, our findings reported here strongly support strategies proposed previously to release only the most effective and best adapted species in a given geographic area according to the climatic conditions (Briggs 1993; Ehler and Hall 1982). This is particularly critical, because most prey arthropods are attacked by more than one natural enemy species (Briggs 1993), and because the use of multiple natural enemy species in biological control of arthropod pests is still a matter of debate (Briggs 1993; Spiller 1986). On the other hand, this argument has been challenged by findings which provided little evidence that one natural enemy species provided higher prey suppression as compared with two or more natural enemy species together (Croft et al. 1992; Huffaker et al. 1971; Lang 2003; Riechert and Lawrence 1997). Interactions among natural enemy species can take two opposite directions with respect to their impact on pest populations (Losey and 
Denno 1999; Onzo et al. 2004; Onzo et al. 2005b). T. aripo and N. tanajoae species may act in a complementary way thereby increasing predation risk to the prey when they are released in different geographic areas. However, when they are released in the same field, the two natural enemy species will negatively interact with each other, thereby decreasing the predation risk to the prey as has been observed with some generalist insect predators of herbivore populations (Rosenheim 2001; Spiller 1986; Roy et al. 2000).

While predation of T. aripo on infected CGM may reduce the potential level of fungus inoculum, the predator, under field conditions, may also enhance spreading of the fungus inoculum while in contact with fungus-killed CGM during its foraging on cassava plants. The relevance of this aspect on a larger spatial scale and under natural conditions remains to be studied in future research.

\section{Acknowledgements}

We are grateful to Honoré Dossounon, Kevin Yenou for their valuable help while collecting and processing samples, Richard Houndafoché for his assistance in rearing the predatory mites, S. Korie for his assistance in the statistical analyses, Professor Dr Italo Delalibera Junior, Muaka Toko, Fabien Hountondji, Désiré Gnanvossou, Birger Koopmann and anonymous reviewers for providing valuable comments on an earlier version of this manuscript. We are grateful to the Deutscher Akademischer Austausch Dienst (DAAD), the International Institute of Tropical Agriculture (IITA) through a grant from the International Fund for Agricultural Development (IFAD), and the University of Göttingen in Germany for supporting this research.

\section{Literature cited}

Agboton,V.B., Delalibera, Jr.I., Hanna, R., von Tiedemann, A., 2009. Molecular detection and differentiation of Brazilian and African strains of the entomopathogen Neozygites tanajoae (Entomophthorales: Neozygitaceae) with PCR using specific primers. Biocontrol Science and Technology 19 (1), 67-79.

Alvarez Afanador, J.M., Acosta, A., Bellotti, A.C., Braun, A.R., 1993. Pathogenicity studies of a fungus associated to the cassava (Manihot esculenta Crantz) pest Mononychellus tanajoa (Bondar). Revista Colombiana de Entomologia 19, 10-20.

Ariori, S.L., Dara, S.K., 2007. Predation of Neozygites tanajoae infected cassava green mites by the predatory mite, Typhlodromalus aripo (Acari: Phytoseiidae). Agriculturae Conspectus Scientificus 72 (2), 169-172.

Boucias, D.G., Pendland, J.C., 1998. Principles of Insect Pathology. Kluwer Academic Publication, Boston, Massachusetts, USA 
Briggs, C.J., 1993. Competition among parasitoid species on a stage-structured host and its effect on host suppression. American Naturalist 141, 372-397.

Croft, B.A., MacRae, I.V., Currans, K.G., 1992. Factors affecting biological control of apple mites by mixed populations of Metaseiulus occidentalis and Typhlodromus pyri. Experimental and Applied Acarology 14, 343-355.

Delalibera, J.I., Sosa-Gómez, D.R., de Moraes, G.J., Alencar, J.A., Farias, A.W., 1992. Infection of Mononychellus tanajoa (Acari: Tetranychidae) by the fungus Neozygites sp. (Entomophthorales) in northeastern Brazil. Florida Entomologist 75, 145-147.

Delalibera, J.I., de Moraes, G.J., Lapointe, S.L., da Silva, C.A.D., Tamai, M.A., 2000. Temporal variability and progression of Neozygites sp. (Zygomycetes: Entomophthorales) in populations of Mononychellus tanajoa (Bondar) (Acari: Tetranychidae). Anais da Sociedade Entomologica do Brasil 29, 523-535.

Delalibera, J.I.,2002. Investigations towards implementation of Neozygites tanajoae sp. Nov. as a classical biological control agent against the cassava green mite in Africa. PhD. Thesis, Cornell University, Ithaca, New York, $141 \mathrm{pp}$.

Delalibera, J.I., Hajek, A.E., Humber, R.A., 2004. Neozygites tanajoae sp. nov., a pathogen of the cassava green mite. Mycologia 96, 1002-1009.

Delalibera, J.I., Hajek, A.E., 2004. Pathogenicity and specificity of Neozygites tanajoae and Neozygites floridana (Zygomycetes: Entomophthorales) isolates pathogenic to the Cassava Green Mite. Biological control 30, 608-616

Delalibera, J.I., 2008. Biological control of the cassava green mite in Africa with Brazilian isolates of the fungal pathogen Neozygites tanajoae. In: Hajek AE, Glare TR, O Callaghan M. (Org.). Use of Microbes for control and eradication of invasive arthropods. New York: Springer 6, 259269.

Ehler, L.E., Hall, R.W., 1982. Evidence for competitive exclusion of introduced natural enemies in biological control. Environmental Entomology 11, 1-4.

Elliot, S.L., de Moraes, G.J., Mumford, J.D., 2008. Failure of the mite-pathogenic fungus Neozygites tanajoae and the predatory mite Neoseiulus idaeus to control a population of the cassava green mite, Mononychellus tanajoa. Experimental and Applied Acarology, doi 10.1007/s10493-008-9164-8

Gnanvossou, D., Hanna, R., Dicke, M., Yaninek, J.S., 2001. Attraction of the predatory mites Typhlodromalus manihoti and Typhlodromalus aripo to cassava plants infested by cassava green mite. Entomologia Experimentalis et Applicata 101, 291-298. 
Gnanvossou, D., Hanna, R., Dicke, M., 2003. Infochemical-mediated intraguild interactions among three predatory mites on cassava plants. Oecologia 135, 84-90.

Hajek, A.E., Wraight, S.P., Vandenberg, J.D., 2001. Control of Arthropods using Pathogenic fungi. Bio-Exploitation of Filamentous Fungi, Fungal Diversity Research Series 6, 309-347.

Hanna, R., Toko, M., 2001. Cassava green mite biological control in Africa: project overview and summary of progress. In: Hanna R and Toko M (eds) Proceedings of the Regional Meeting of the Cassava Green Mite Biocontrol Project, Dar es Salaam, Tanzania, 15-17 November 2000. IITA, Cotonou, pp. 4-22.

Heinz, K.M., Nelson, J.M., 1996. Interspecific interactions among natural enemies of Bemisia in an innundative biological control program. Biological Control 6, 284-393.

Hountondji, F.C.C., Lomer, C.J., Hanna, R., Cherry, A.J., Dara, S.K., 2002a. Field evaluation of Brazilian isolates of Neozygites floridana (Entomophthorales: Neozygitaceae) for the microbial control of cassava green mite in Benin, West Africa. Biocontrol Science and Technology 12, 361-370.

Hountondji, F.C.C., Yaninek, J.S., de Moraes, G.J., Oduor, G.I., 2002b. Host specificity of the cassava green mite pathogen Neozygites floridana. BioControl 47, 61-66

Hountondji, F.C.C., Hanna, R., Cherry, A.J., Sabelis, M.W., Agboton, V.B., 2007. Scaling up tests on virulence of the cassava green mite fungal pathogen Neozygites tanajoae (Entomophthorales: Neozygitaceae) under controlled conditions: first observations at the population level. Experimental and Applied Acarology 41, 153-168.

Hountondji, F.C.C., 2008. Lessons from interaction within the cassava green mite fungal pathogen Neozygites tanajoae system and prospects for microbial control using Entomophthorales. Experimental and Applied Acarology 46, 195-210.

Huffaker, C.B., Messenger, P.S., DeBach, P., 1971. The natural enemy component in natural control and the theory of biological control. In: Huffaker CB. (Ed.), Biological Control. Plenum Press, New York, pp. 16-67.

Lang, A., 2003. Intraguild interference and biocontrol effects of generalist predators in a winter wheat field. Oecologia 134, 144-153.

Littell, R.C., Pendergast, J., Natarajan, R., 2000. Tutorial in biostatistics: Modelling covariance structure in the analysis of repeated measures data. Statistics in Medicine 19, 1793-1819.

Losey., J.E., Denno, R.F., 1998. Positive predator-predator interactions: enhanced predation rates and synergistic suppression of aphid populations. Ecology 79, 2143-2152.

Losey, J.E., Denno, R.F., 1999. Factors facilitating synergistic predation: the central role of synchrony. Ecological Application 9, 378-386. 
Onzo, A., Hanna, R., Zannou, I., Sabelis, M.W., Yaninek, J.S., 2003. Dynamics of refuge use: Diurnal, vertical migration by predatory and herbivorous mites within cassava plants. Oikos 101, 59-69.

Onzo, A., Hanna, R., Janssen, A., Sabelis, M.W., 2004. Interactions between two neotropical phytoseiid predators on cassava plants and consequences for biological control of a shared spider mite prey: a screenhouse evaluation. Biocontrol Science and Technology 14, 63-76.

Onzo, A., Hanna, R., Sabelis, M.W., 2005a. Biological control of cassava green mites in Africa: impact of the predatory mite Typhlodromalus aripo. Entomologische Berichten 65 (1) 2005.

Onzo, A., Hanna, R., Negloh, K., Toko, M., Sabelis, M.W., 2005b. Biological control of cassava green mite with exotic and indigenous phytoseiid predators-Effects of intraguild predation and supplementary food. Biological Control 33, 143-152.

Polis, G.A., Myers, C.A., Holt, R.D., 1989. The ecology and evolution of intraguild predation: potential competitors that eat each other. Annual Review of Ecology and Systematics 20, 297330.

Riechert, S.E., Lawrence, K., 1997. Test for predation effects of single versus multiple species of generalist predators: spiders and their insect prey. Entomologia Experimentalis et Applicata 84, 147-155.

Rosenheim, J.A., 2001. Source-sink dynamics for a generalist insect predator in habitats with strong higher-order predation. Ecological Monographs 71, 93-116.

Roy, H.E., Pell, J.K., 2000. Interaction between entomopathogenic fungi and other natural enemies: implications for biological control. Biocontrol Science and Technology 10, 737-752.

SAS Institute 2007. SAS system for Windows, Statistics. Release 6.12, version 9.1. SAS Institute Inc., Cary, NC, USA.

Sih, A., Englund, G., Wooster, D., 1998. Emergent impact of multiple predators on prey. Trends in Ecology and Evolution 13, 325-329.

Spiller, D.A., 1986. Interspecific competition between spiders and its relevance to biological control by general predators. Environmental Entomology 15, 177-181.

Wekesa, V.W., de Moraes, G.J., Knapp, M., Delalibera, J.I., 2007. Interactions of two natural enemies of Tetranychus evansi, the fungal pathogen Neozygites floridana (Zygomycetes: Entomophthorales) and the predatory mite, Phytoseiulus longipes (Acari: Phytoseiidae). Biological control 41, 408-414

Yaninek, J.S., Saizonou, S., Onzo, A., Zannou, I., Gnanvossou, D., 1996. Seasonal and habitat variability in the fungal pathogens: Neozygites cf. floridana and Hirsutella thompsonii, associated with cassava mites in Benin. Biocontrol Science and Technology 6, 23-33. 
Yaninek, J.S., Megevand, B., Ojo, B., Cudjoe, A.R., Abolee., Onzo, A., Zannou, I., 1998. Establishment and spread of Typhlodromalus manihoti (Acari: Tetranychidae) in Africa. Environmental Entomology 276, 1496-1505.

Yaninek, J.S., Hanna, R., 2003. Cassava green mite in Africa: a unique example of successful classical biological control of a mite pest on a continental scale. In: P. Neuenschwander, C. Borgemeister and L. Langewald (eds.) Biological control in IPM systems in Africa. CABI Publishing, Wallingford, UK, pp. 61-75.

Zannou, I.D., Hanna, R., Agboton, V.B., de Moraes, G.J., Kreiter, S., Phiri, G., Jone, A., 2007. Non-target effects of the classical biological control of a neotropical herbivorous mite pest Mononychellus tanajoa (Acari: Tetranychidae) a mite pest of cassava in Southern Africa. Biological Control, Volume 41, Issue 2, May 2007, 190-198. 
Table 1. Mixed Model repeated measures ANOVA of treatment and sampling date on densities of Mononychellus tanajoa, Typhlodromalus aripo and Neozygites tanajoae in the greenhouse experiments. Neo indicates $N$. tanajoae, Ta indicates $T$. aripo ( $d f$, degrees of freedom).

\begin{tabular}{|c|c|c|c|c|c|c|c|c|c|}
\hline \multirow[b]{2}{*}{ Source of variation } & \multicolumn{3}{|c|}{ M. tanajoa } & \multicolumn{3}{|c|}{ T. aripo } & \multicolumn{3}{|c|}{ N. tanajoae } \\
\hline & $\mathrm{df}$ & $F$ & $P$ & $\mathrm{df}$ & $F$ & $P$ & $\mathrm{df}$ & $F$ & $P$ \\
\hline Natural enemies & 3 & 5.25 & 0.0271 & 1 & 2.22 & 0.2287 & 1 & 11.28 & 0.0284 \\
\hline Date & 2 & 1.45 & 0.2908 & 2 & 10.70 & 0.0095 & 2 & 4.68 & 0.0451 \\
\hline Natural enemies*Date & 6 & 3.28 & 0.0620 & 2 & 2.32 & 0.1761 & 2 & 2.33 & 0.1590 \\
\hline \multicolumn{10}{|l|}{ Contrasts } \\
\hline Neo vs. Control & 1 & 1.10 & 0.3254 & - & - & - & 1 & - & - \\
\hline Ta vs. Control & 1 & 14.52 & 0.0052 & - & - & - & 1 & - & - \\
\hline $\mathrm{Neo}+\mathrm{Ta} v s$. Control & 1 & 1.49 & 0.2575 & - & - & - & 1 & - & - \\
\hline Neo vs. Ta & 1 & 7.64 & 0.0245 & - & - & - & 1 & - & - \\
\hline Neo+Ta $v s . \mathrm{Ta}$ & 1 & 6.72 & 0.0320 & 1 & 3.15 & 0.2287 & 1 & - & - \\
\hline $\mathrm{Neo} v s . \mathrm{Neo}+\mathrm{Ta}$ & 1 & 0.03 & 0.8680 & - & - & - & 1 & 11.28 & 0.0284 \\
\hline
\end{tabular}

A

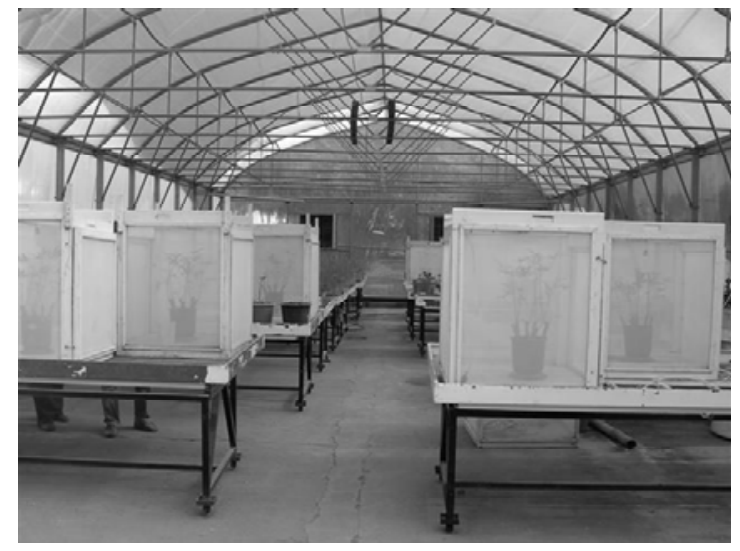

Group of cages kept inside the screenhouse at IITA-Benin

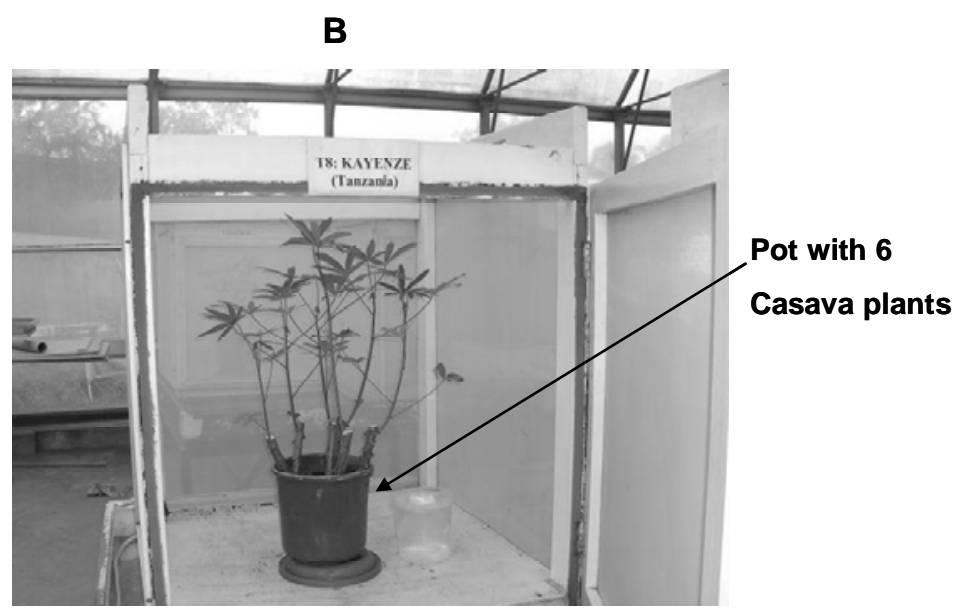

Each treatment

Figure 1. Cages placed on iron benches inside a greenhouse in 3 groups (replicates) of 4 cages, each corresponding to one treatment. Each group (A) of cages represents one replicate of the experiment. Each treatment consisted on release of a particular natural enemy ( $T$. aripo or $N$. tanajoae) to host mites on potted cassava plants inside each cage (B). 

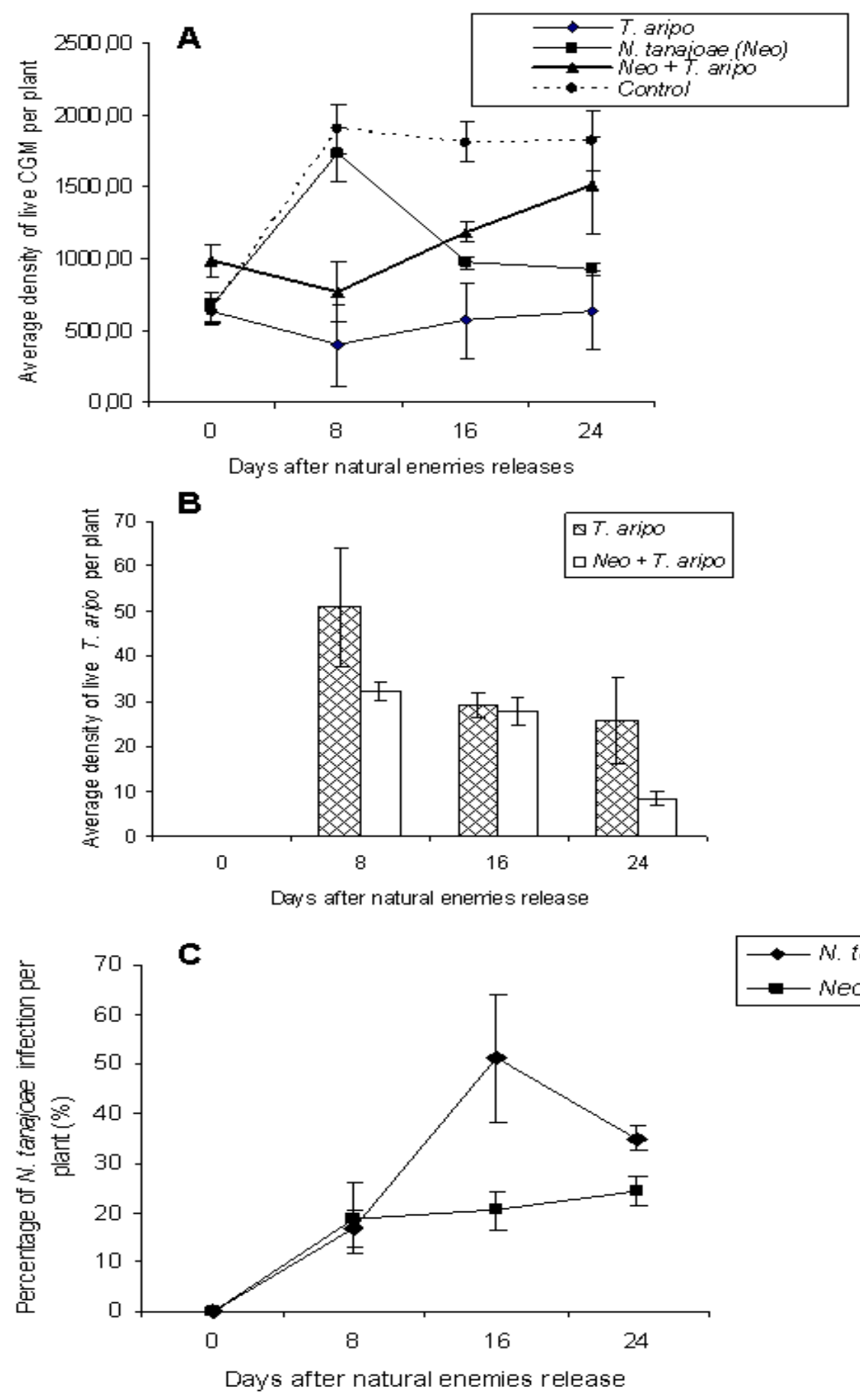

Figure 2. Population densities of CGM, T. aripo, and N. tanajoae, respectively on plants in the different treatments in the greenhouse experiment: (A) CGM (actives), (B) T. aripo (actives) and (C) N. tanajoae (infected and mummified mites). Counts were log-transformed; proportions of $N$. tanajoae-infected CGM were arcsine-transformed for normalizing the data and averaged per plant. Day 0 is the day on which natural enemies were added. 


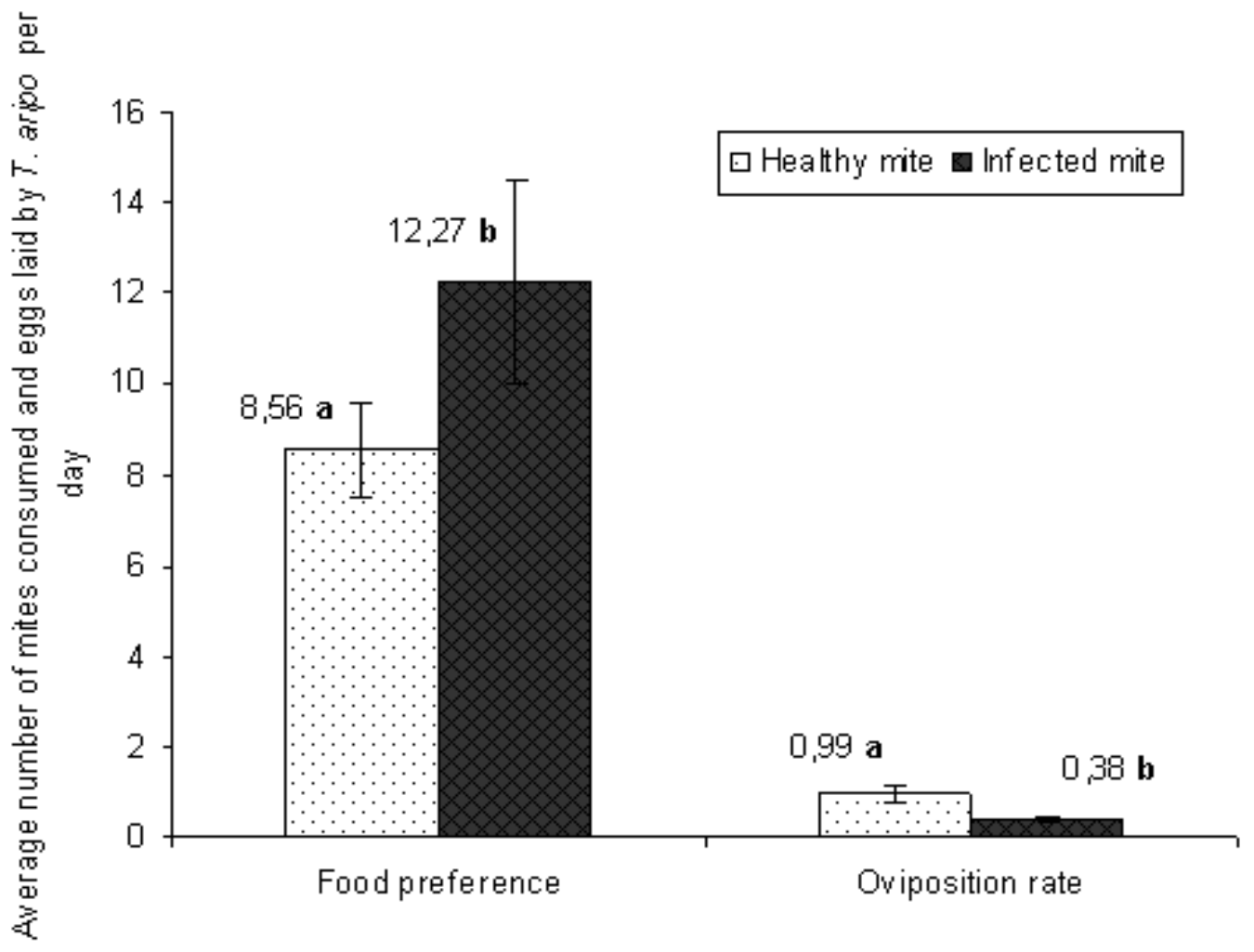

Figure 3. Food preference of T. aripo per day, and the effect of diet type on the oviposition rate in the laboratory experiment. Significant differences $(\mathrm{P}<0.05$; ANOVA, with SNK mean separation; SAS Institute, 2007) are indicated with different letters. 


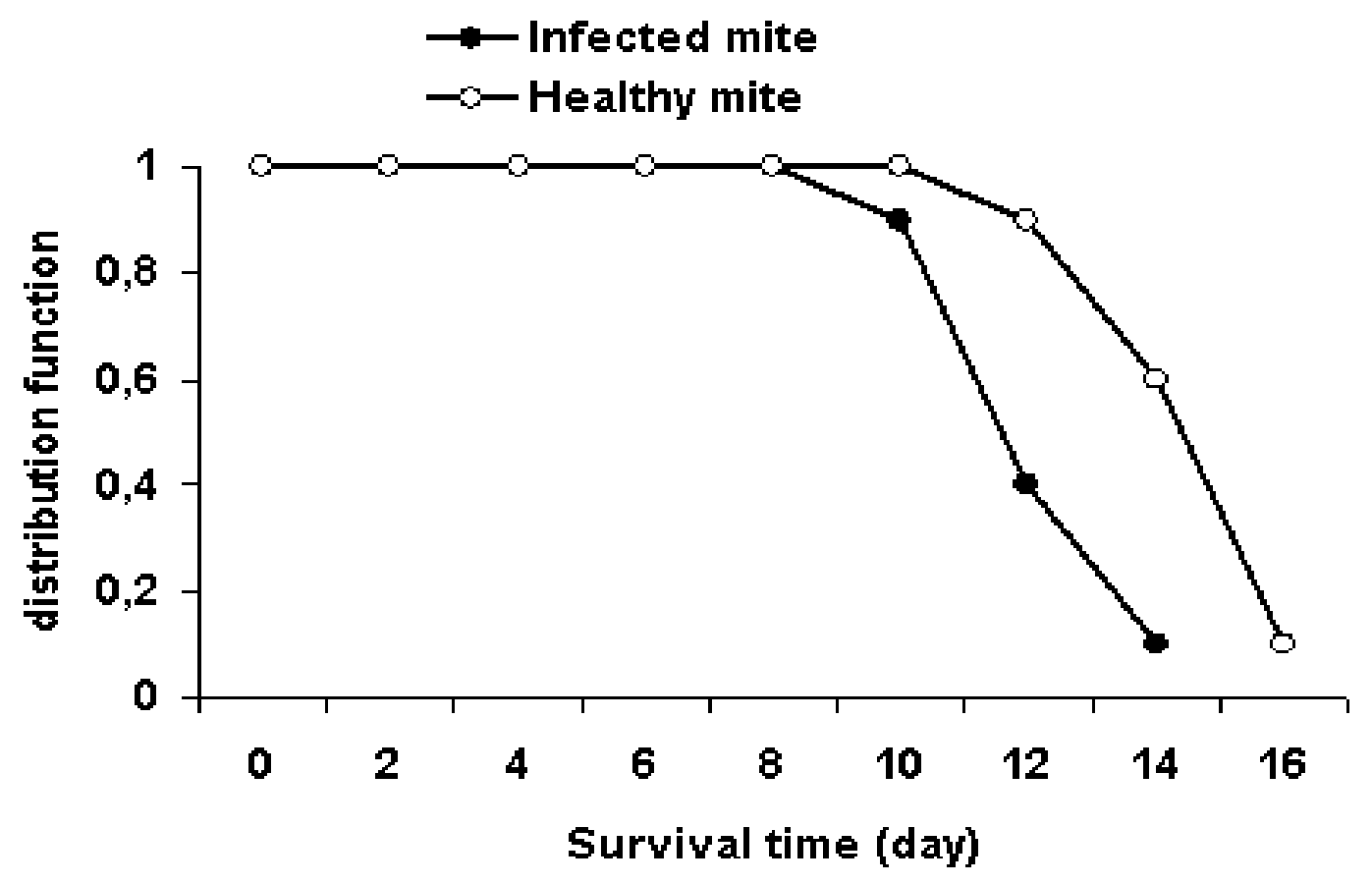

Figure 4. Survival curves of Typhlodromalus aripo feeding on two different diets (infected mite by $N$. tanajoae and healthy mite) tested in a laboratory experiment. 


\section{General Discussion}

In order to complement the biocontrol activities of phytoseiid predators, the pathogenic fungus $N$. tanajoae, one of the most efficient natural enemies of the CGM in Brazil (Delalibera 2002) has been introduced experimentally in Benin (West Africa) in 1998/1999 for the control of cassava green mite. N. tanajoae strains from Brazil are morphologically similar to strains found in Africa and other countries in South America (Delalibera et al., 2004). Consequently, it is difficult to conduct a post-release monitoring of introduced species in Africa as no reliable techniques were available for differentiating among African and Brazilian isolates of $N$. tanajoae. To overcome this constraint, two specific pairs of oligonucleotide primers were designed in 2003 for Polymerase Chain Reaction (PCR) detection and determination of geographic strains of N. tanajoae from Brazil and Africa. The development of the probes was based on a collection of Brazilian strains and on only one African strain from Benin (West Africa). Therefore, there was a requirement to verify the applicability of the probes with more indigenous strains of $N$. tanajoae from post-release fields in Africa.

In the first step of this research the probes were tested for identifying and differentiating $N$. tanajoae strains collected from a broader range of locations, allowing for a large-scale analysis of the entomopathogen population in various cassava-growing regions. DNA of $N$. tanajoae was obtained from in vivo produced isolates and a PCR assay was established capable of detecting fungal DNA within the complex matrix of infected mites. A similar example of conidia being successfully used for ITS-based PCR identification is the Leptosphaeria maculans species complex (Balesdent et al. 1998). Thus, mummified mites from several geographic regions in Brazil and Africa were tested for their capacity to produce infective capilliconidia of $N$. tanajoae, which was taken as characteristic of a viable sample. The sporulation test used in this study therefore served a dual purpose, as a suitable method for the detection of $N$. tanajoae infected mites and as a check for viability of the fungus and for the inoculation of host mites under controlled conditions.

The present study independently validated the two primer pairs for the first time and determined that $52^{\circ} \mathrm{C}$ was a suitable annealing temperature in a PCR assay to materialize the specificity of the used primers. Similar techniques have been used by Ersek et al. (2003) for identifying hybrids within Phytophthora alni with PCR-based DNA markers. In fact, PCR with genomic DNA extracted from mites infected with different strains of $N$. tanajoae produced a clear banding pattern according to the correspondent primer while uninfected mites and sterile water did not produce any such signals. These results confirmed the high 
specificity of NEOSSU and 8DDC primers as a key for $N$. tanajoae detection and differentiation, thus confirming previous work by Delalibera et al. (unpublished) on a limited number of isolates. A similar study was conducted by Bonants et al. (2003) on detection and identification of Phytophthora fragariae with polymerase chain reaction by using speciesspecific primers.

As a result of the present studies, the two oligonucleotide primer pairs turned out to be suitable for following the establishment and spread of Brazilian strains in the framework of the campaign on biocontrol of the cassava green mite in cassava fields in Benin. In fact, the results presented here provide evidence of the establishment in Benin of the Brazilian entomopathogenic fungal strains found associated with cassava green mite upon PCR detection with specific primers. A similar molecular approach has been used by Nakabonge et al. (2006) on different pathogens of Chrysoporthe spp. to follow their distribution in Eastern and Southern Africa. Moreover, this study has greatly increased our knowledge on the distribution in Benin of the most important pathogen of Mononychellus tanajoa currently known. This is the first time that molecular markers were used for monitoring the status of $N$. tanajoae in the Republic of Benin, where the Brazilian isolates have been released since 1999. Similarly to the finding of Yaninek et al. (1996), our results suggest that certain locations may be more favourable for the establishment and survival of the pathogen (Larsen et al. 2007) and infection of CGM. Thus, the number of cassava fields associated with $N$. tanajoae was higher in the south where the agro-ecological conditions are more favourable for cassava production. The annual precipitation is generally greater in southern than northern Benin which could enhance the fungal pathogenicity and may explain the highest infection rate found in southern Benin (Yaninek et al. 1996). Interestingly, overall infection rates of CGM were significantly correlated with the prevalence of Brazilian isolates in cassava fields indicating a stronger biocontrol potential of the exotic pathogen strains to the suppression of CGM.

Information presented here will be a key element for an appropriate post-release monitoring of $N$. tanajoae, which will improve follow-up strategies for the use of entomopathogenic fungi in any microbiological control program.

Although the molecular technique was reliable for differentiating among $N$. tanajoae strains and for following their dispersal in the release areas, the need for alternative methods still exists due to the high cost of molecular assays. Among the possible methods, attention was turned to the biocontrol potential and host ranges comparison of Brazilian and African isolates of $N$. tanajoae. Our investigations have demonstrated that the evaluation of biocontrol 
potential at individual and population levels show the biological capacity of each isolate studied, however, this did not offer an opportunity differentiate among isolates of different origin due to the variability obviously existing in $N$. tanajoae populations. On the whole, the expectation of this work was that Brazilian and African isolates, both tested at individual and population level against CGM and also evaluated for their host range specificity, would reveal distinct differences according to their geographic origin. This could have opened options for alternative methods of differentiating between Brazilian and African strains. However, while the present work has not verified these expectations, which is in line with previously found diagnostic approaches (Lee et al. 1993; Bonants et al. 1997; Brasier et al. 1999; Judelson and Tooley. 2000), it emphasizes the requirement of applying molecular genetic assays for the differentiation of these strains as recently demonstrated (Agboton et al. 2008). In addition, this work gives proof of the suitability of in vivo methods to test the biocontrol potential and host range of different $N$. tanajoae isolates in order to evaluate the biocontrol effectiveness of this entomopathogen against cassava green mite under controlled conditions.

Finally, the important finding in this work is that there is no adverse entomopathogenic impact by $N$. tanajoae on phytoseiid mites, particularly beneficial ones like Typhlodromalus aripo, an important predator for the control of M. tanajoa on cassava in Africa. This suggests a follow-up investigation on potential synergistic interactions of both natural enemies ( $T$. aripo and $N$. tanajoae) of M. tanajoa in the same habitat.

T. aripo and N. tanajoae are used in Africa in an integrated pest management system against the cassava green mite in the same cassava agroecosystems. Pathogens and arthropod natural enemies may concomitantly contribute to the suppression of the CGM population either as individual species or as species complexes. Our investigation of the interaction of both natural enemies ( $T$. aripo and $N$. tanajoae) sharing the same host ( $M$. tanajoa) on cassava showed that in separate applications, T. aripo and $N$. tanajoae can significantly suppress $M$. tanajoa populations, hereby confirming previous observations on impact of $T$. aripo (Hanna et al. 2001; Onzo et al. 2003; Yaninek and Hanna 2003), or on impact of $N$. tanajoae (Alvarez et al. 1993; Hajek et al. 2001; Delalibera et al. 2004; Hountondji et al. 2002a; Hountondji et al. 2007). However, in our experimental conditions, T. aripo is more effective than $N$. tanajoae in suppressing CGM populations. This higher performance of $T$. aripo is likely due to its ability to feed directly on $M$. tanajoa, while $N$. tanajoae is an entomopathogen which takes some time to develop an infection inside $M$. tanajoa before killing it (Hajek et al. 2001). Indeed, for many species of entomopathogenic fungi, hosts are killed only after full colonization resulting in depletion of nutrients (Hajek et al. 2001). 
Moreover, our hypothesis was that the two natural enemy species would complement each other in suppressing M. tanajoa, as both share the same host. This expected complementarity was however not evident in our experiments, as the co-occurrence of T. aripo and N. tanajoae on the same cassava plant in the screenhouse did not add significantly to the suppression of M. tanajoa achieved by $T$. aripo alone. On the contrary, our results suggest an indirect interspecific interaction between $T$. aripo and $N$. tanajoae, because in our previous research $N$. tanajoae did not directly affect T. aripo (Hountondji et al. 2002b; Agboton et al. submitted). Indeed, by preferred feeding on infected mites, T. aripo reduces the fungal inoculum and negatively affects its own reproduction rate, which in turn increases $M$. tanajoa densities. Our findings are supported by Ariori et al, (2007), who suggested that the consumption of pathogen-infected pest mites by predatory mites can reduce the effectiveness of the microbial control agent. In our study the regression analysis between proportions of both natural enemies in mixed treatments revealed that high $T$. aripo densities were associated with low N. tanajoae infection rates. This could partly explain the variations observed when both enemies were released together in the same habitat; as well as the failure of the mitepathogenic fungus N. tanajoae and another predatory mite, Neoseiulus idaeus, to control a population of cassava green mite in central Bahia, Brazil (Elliot et al. 2008). Overall, by releasing in the same fields, the two natural enemy species will interfere indirectly with each other through interspecific interactions thereby decreasing the predation risk to the prey like it has been observed in other works with generalist insect predators on the suppression of an herbivore population (Rosenheim 2001; Spiller 1986; Roy et al. 2000).

In conclusion, this thesis has shown how molecular techniques are indispensable for post-release studies of the introduced entomopathogenic fungal N. tanajoae in Africa. The research presented has led to validate a probe for $N$. tanajoae detection and its different strains differentiation. Furthermore, the research has led also to better understanding of the biology and ecology of both exotic natural enemies (pathogens and arthropod) that are used to control the cassava green mite in the cassava habitat in Africa.

There are more questions to be answered with Neozygites tanajoae in order to improve the understanding of the use of entomopathogenic fungi in the biological control of herbivores. Future investigations will have to address the following aspects:

1- Impact of Brazilian strains of N. tanajoae on population dynamics of local Africans strains under field conditions. 
2- Factors affecting the loss in biocontrol potential of exotic species of Neozygites tanajoae in their new introduced environment.

3- Investigation on the genome of post release collection and African collection.

4- Determine the relative contribution of each natural enemy species to biological control of M. tanajoa in the short and long term and their interaction at a larger spatial scale and under natural conditions.

5- Study the potential role of the predator (T. aripo) in spreading fungal inoculum while in contact with fungus-killed $M$. tanajoa during its foraging process on cassava plants.

\section{References}

Agboton VB, Delalibera JrI, Hanna R, von Tiedemann A. 2008. Molecular detection and differentiation of Brazilian and African isolates of the entomopathogen Neozygites tanajoae (Entomophthorales: Neozygitaceae) with PCR using specific primers. Biocont. Sci Tech. (in press).

Alvarez Afanador JM, Acosta A, Bellotti AC, Braun AR. 1993. Pathogenicity studies of a fungus associated to the cassava (Manihot esculenta Crantz) pest Mononychellus tanajoa (Bondar). Rev. Colomb. Entomol. 19: 10-20.

Ariori SL, Dara SK. 2007. Predation of Neozygites tanajoae infected cassava green mites by the predatory mite, Typhlodromalus aripo (Acari: Phytoseiidae). Agri Cons Sci. 72 No.2 169-172.

Balesdent MH, Jedryczka M, Jain L, Mendes-Pereira E, Bertrandy J, Rouxel T. 1998. Conidia as a substrate for Internal Transcribed Spacer-Based PCR identification of members of the Leptosphaeria maculans species complex. Phytopathology 88: 1210-1217.

Bonants P, Hagenaar-de Weerdt M, van Gent-Pelzer M, Lacourt I, Cooke D, Duncan J. 1997. Detection and identification of Phytophthora fragariae Hickman by the polymerase chain reaction. Eur. J. Plt Path. 103: 345-355.

Bonants PJM, Carroll GC, DeWeerdt M, Van Brouwershaven IR, Baayen RP. 2003. Development and validation of a fast PCR-based detection method for pathogenic isolates of the citrus black spot fungus, Guignardia citricarpa. Eur. J. Plt Path. 109: 503-513.

Brasier CM, Cooke DEL, Duncan JM. 1999. Origin of a new Phytophthora pathogen through interspecific hybridization. Proceeding of the National Academy of Sciences 96: 58785883. 
Delalibera JrI. 2002. Investigations towards implementation of Neozygites tanajoae sp. Nov. as a classical biological control agent against the cassava green mite in Africa. $\mathrm{PhD}$. Thesis, Cornell University, Ithaca, New York, 141 pp.

Delalibera JrI, Hajek AE, Humber RA. 2004. Neozygites tanajoae sp. Nov, a pathogen of the cassava green mite. Mycologia 96: 1002-1009.

Elliot SL, de Moraes GJ, Mumford JD. 2008. Failure of the mite-pathogenic fungus Neozygites tanajoae and the predatory mite Neoseiulus idaeus to control a population of the cassava green mite, Mononychellus tanajoa. Exp Appl Acarol. doi 10.1007/s10493008-9164-8

Ersek T, Bakonyi J, Nagy ZA. 2003. PCR-based marker for identification of interspecific Phytophthora hybrids attacking alder trees. In: Kövics Gy (ed), From Ideas to Implementation: Challenge and practice of Plant Protection in the Beginning of the $21^{\text {st }}$ Century. Proceedings $3^{\text {rd }}$ International Plant Protection Symposium. Debrecen, Hungary, Debrecen University, 2003, pp. 85-86.

Hajek AE, Wraight SP, Vandenberg JD. 2001. Control of Arthropods using Pathogenic fungi, pp. 309-347. In (S.B. Pointing \& K.D. Hyde, Eds.) Bio-Exploitation of Fungi. Fungal Diversity Press, Hong Kong.

Hanna R and Toko M. 2001. Cassava green mite biological control in Africa: project overview and summary of progress. In: Hanna R and Toko M (eds) Proceedings of the Regional Meeting of the Cassava Green Mite Biocontrol Project, Dar es Salaam, Tanzania, 15-17 November 2000. IITA, Cotonou, pp. 4-22

Hountondji FCC, Lomer CJ, Hanna R, Cherry AJ, Dara SK. 2002a. Field evaluation of Brazilian isolates of Neozygites floridana (Entomophthorales: Neozygitaceae) for the microbial control of cassava green mite in Benin, West Africa. Biocont. Sci Tech. 12: 361-370.

Hountondji FCC, Yaninek JS, de-Moraes GJ, Oduor GI. 2002b. Host specificity of the cassava green mite pathogen Neozygites floridana. BioControl 47: 61-66.

Hountondji FCC, Hanna R, Cherry AJ, Sabelis MW, Agboton VB, Korie S. 2007. Scaling up tests on virulence of the cassava green mite fungal pathogen Neozygites tanajoae (Entomophthorales: Neozygitaceae) under controlled conditions: first observations at the population level. Exp. Appl. Acarol. 41: 153-168.

Judelson HS, Tooley PW. 2000. Enhanced polymerase chain reaction methods for detecting and quantifying Phytophthora infestans in plants. Phytopathology 90: 1112-1119. 
Larsen JE, Hollingsworth CR, Flor J, Dornbusch MR, Simpson NL, Samac DA. 2007. Distribution of Phoma sclerotioides on alfalfa and winter wheat crops in the North Central United States. P1. Dis. 91: 551-558

Lee SB, White TJ, Taylor JW. 1993. Detection of Phytophthora species by oligonucleotide hybridization to amplified ribosomal DNA spacers. Phytopathology 83: 177-181.

Nakabonge G, Roux J, Gryzenhout M, Wingfield MJ. 2006. Distribution of Chrysoporthe canker pathogens on Eucalyptus and Syzygium spp. in eastern and southern Africa. Pl. Dis. 90: $734-740$

Onzo A, Hanna R, Zannou I et al. 2003. Dynamics of refuge use: Diurnal, vertical migration by predatory and herbivorous mites within cassava plants. Oikos 101: 59-69.

Rosenheim JA .2001. Source-sink dynamics for a generalist insect predator in habitats with strong higher-order predation. Ecol Monogr 71: 93-116.

Roy HE, Pell JK. 2000. Interaction between entomopathogenic fungi and other natural enemies: implications for biological control. Biocont. Sci Tech. 10: 737-752.

Spiller DA. 1986. Interspecific competition between spiders and its relevance to biological control by general predators. Environ Entomol 15: 177-181.

Yaninek JS, Saizonou S, Onzo A, Zannou I, Gnanvossou D. 1996. Seasonal and habitat variability in the fungal pathogens: Neozygites cf. floridana and Hirsutella thompsonii, associated with cassava mites in Benin. Biocont. Sc. Tech. 6: 23-33

Yaninek JS and Hanna R. 2003. Cassava green mite in Africa: a unique example of successful classical biological control of a mite pest on a continental scale. In: P. Neuenschwander, C. Borgemeister and L. Langewald (eds.) Biological control in IPM systems in Africa. CABI Publishing, Wallingford, UK, pp. 61-75. 


\section{List of publications}

Agboton, V.B., Delalibera Jr, I., Hanna, R., von Tiedemann, A. 2009. Molecular detection and differentiation of Brazilian and African isolates of the entomopathogen Neozygites tanajoae (Entomophthorales: Neozygitaceae) with PCR using specific primers. Biocontrol Science and Technology 19 (1), 67-79.

Hountondji F.C., Hanna, R., Cherry A. J., Sabelis, M.W., Agboton, V.B., Korie S. 2007; Scaling up tests on virulence of the cassava green mite fungal pathogen Neozygites tanajoae (Entomophthorales: Neozygitaceae) under controlled conditions: first observations at the population level. Experimental and Applied Acarology, volume 41, Number 3 March 2007, Page 153-168

Zannou I. D., Hanna, R, Agboton, V.B., De Moraes G. J. and Kreiter S. 2007, Non-target effects of the classical biological control of a neotropical herbivorous mite pest Mononychellus tanajoa (Acari: Tetranychidae) a mite pest of cassava in Southern Africa . Biological Control, Volume 41, Issue 2, May 2007, Page 190-198

Agboton, V.B., Hanna, R., Odjo, A., T, Goergen, G. 2006; Effect of Ants in Biological Control of a neotropical herbivorous mite pest Mononychellus tanajoa (Acari: Tetranychidae) a mite pest of cassava plant in Africa. Conference Proceedings Tropentag 2006. International Research on Food Security, Natural Resource Management and Rural Development University of Bonn, http://www.tropentag.de/2006/proceedigs/node176.html\#4161;

Full paper: http://www.tropentag.de/2006/abstracts/full/71.pdf

Agboton, V.B., Hanna, R., Odjo, A., T, Goergen, G. 2006, Ants associated with cassava in southern Benin and indirect effects on biological control of cassava green mite. XIIth International Congress of Acarology, 21-26 August 2006, Amsterdam, the Netherlands, Page 6 of Abstract book, http://www.acarology.org/ ica2006/

Agboton, V.B., Hanna, R., von Tiedemann, A. Molecular detection of establishment and dispersal of Brazilian isolates of Neozygites tanajoae in Benin (West Africa) a fungus pathogenic to cassava green mite. BioControl (submitted) 
Agboton, V.B., Hanna, R., Hountondji, F.C.C., von Tiedemann, A. Pathogenicity and host specificity of Brazilian and African isolates of the acaropathogenic fungus Neozygites tanajoae to mite species associated with cassava. Journal of Applied Entomology (submitted)

Agboton, V.B., Hanna, R., Onzo, A., Vidal, S., von Tiedemann, A. Interactions between the entomopathogenic fungus Neozygites tanajoae and the predatory mite Typhlodromalus aripo in the biological control of cassava green mite (Mononychellus tanajoa). Biological Control (in preparation) 


\section{Acknowledgements}

Glory be to the Almighty God for his blessing, protection and care during all this process. Sincere thanks for his many blessings in my life since my birth until now and for coming days. Thank you JESUS.

I am very grateful to the Government of Germany through Deutscher Akademischer Austauschdienst (DAAD) fellowship; to the International Institute of Tropical Agriculture (IITA) through a field work grant from the International Fund for Agricultural Development (IFAD), and to the University of Goettingen (Germany) for its financial support.

Special thanks to Prof. Dr. Andreas von Tiedemann for having accepted to be my promoter and providing me high quality assistance during this work. I really appreciate your invaluable contributions and assistance throughout my studies at Goettingen. Your critical comments and useful suggestions on my works were very stimulating and I should hope that the collaboration we have started since 2005 shall continue and flourish throughout my career as scientists. Dear Andreas, thanks for trusting me and encouraging me from the beginning of this project. I say God bless you!

I am very much indebted to you, Dear Dr. Rachid Hanna (IITA-Benin) for believing in my capacity to do these studies and accepting to be my co-promoter, for your technical assistance, critical comments and useful suggestions throughout the different phases of my thesis works. Special thanks for giving me materials and financial support for my field works in Benin.

I would like to express my deep gratitude to Prof. Dr. I. Jr. Delalibera of the Department of Entomology at the University of Sao Paolo (Brazil) for accepting to teaching me the first necessary techniques on cryopreservation, isolation and molecular characterization on fungal pathogen in his laboratory at Piracicaba (Sao Paolo, Brazil). I appreciate his support during the first months of the research phase. Thank you very much!

I am very much grateful to Dr. Birger Koopmann, who contributed immensely to the success of this work. I appreciate his advice and guidance, especially during my molecular works in the Department of Crop Sciences at the University of Goettingen (Germany).

I am indebted to Prof. Dr. Stefan Vidal, Head of Section of Entomology at the Department of Crop Sciences (University of Goettingen) for co-supervising my studies. I appreciate his comments and recommendations during the presentation of my results. You 
supported my research and facilitated the extension of my scholarship to the end of this thesis. Thank you Professor Vidal!

Thanks to Dr Marie-Noelle Ndjiondjop of WARDA (Cotonou-Benin) for allowing me to use her laboratory facilities for my molecular works when I was in Benin.

Special thanks to Dr. A. Onzo, Dr. M. Toko, Dr. I. Zannou, Dr. E. Zannou, Dr. D. Gnanvossou, Dr. F. Hountondji and all anonymous reviewers for their critical comments on earlier versions of the chapters.

I would like to express my gratitude to Mr. Sam Korie for statistical assistance; to Honoré Dossounon, Kévin Yenou for their technical assistance during my laboratory works.

My special thanks to IITA drivers especially Marcelin Adandé and Mathieu Houssou for their careful driving whenever we went to fields to collect samples in cassava fields.

I do not forget my colleagues Koffi Negloh and N. Famah from IITA-Benin; Ftayeh Radwan with who I have shared my office and all my colleagues at the Departments of Crop Sciences at the University of Goettingen. They were there for me and complemented my efforts when I needed it the most.

I cannot end without thanking my family especially my mother Marguerite Agossavi, father Honoré Y. Agboton and all my brothers and sisters without forgetting my mother in love Ginette Vieyra (who takes care of my son Eden Junior Agboton during all this period), for the constant encouragement, support and love you always provide me. God bless you all!

Finally, there are a number of individuals who contributed in one way or the other to this dissertation. It is impossible to name each and every one of them. To all those whose names are inadvertently left out, please accept my sincere and warmest gratitude.

Je voudrais enfin exprimer ma profonde gratitude à Viviane Agboton, Eusèbe Agboton, Daniel Agboton, Pulcherie Agboton, Narcisse Agboton, Lazare Hounsa ${ }^{+}$, Eden Agboton, Grece Agboton, Carlos Agboton, Rosemonde Abiko ${ }^{+}$, Sabine Salako, Ulrick Koundé et Edwige Semodji. Je vous aime tous!

Enfin je n'oublie pas mon amie Nina Haftmann pour son soutien durant mon sejour en Allemagne. 


\section{Curriculum vitae}

Bonaventure Vidjannagni Agboton was born on December $8^{\text {th }}, 1974$ at Klouékanmè (Couffo), in the Republic of Benin (West Africa). From 1979 to 1982 he did his primary school education at "Ecole Primaire de Base de Klouékanmè", then moved to "Ecole Primaire de Base de Sobè" (Ifangni, Ouémé-Plateau) from 1982 to 1986 when he completed his primary school education and obtained his primary school certificate (C.E.F.E.B) in 1986. From 1986 to 1991 he undertook his secondary school education at "Collège d'Enseignement Général d'Akpassa" (Porto-Novo, Ouémé) before moving to high school education at "Lycée Toffa ${ }^{\text {ler }}$ at Porto-novo in 1991 where he obtained his secondary school certificate (B.E.P.C) in 1993 and graduated in 1995 with a "Baccalaureat scientifique" degree. In the same year he was awarded a Benin state government scholarship and joined the Faculty of Agricultural Sciences (FSA) at the University of Abomey-Calavi (formerly University National of Benin). After four year studies in general agronomy and entomology he obtained a "Diplôme d'Agronomie Générale" (DAG), which is equivalent to a Bachelor in Agronomy in May 1999. He graduated in December 2000, with the Diplôme d'Ingenieur Agronome (Option: Production Végétale, Protection des Végétaux) equivalent to a M.Sc. degree.

In January 2001, he was selected for a position of Research Assistant with the Biological Control Program initiated against the cassava green mite, Mononychellus tanajoa, by the International Institute of Tropical Agriculture (IITA). Based on this contract, he worked at the Biological Control Centre for Africa based at IITA Benin Station in Cotonou from January 2001 to December 2004. During this period, he was responsible for carrying-out pre-release surveys on cassava green mite and its natural enemy species, releasing and monitoring all exotic predator species and entomopathogenic fungus introduced into many countries in the cassava belt in Africa from Latin America against the pest mite. He was involved in all activities of the program including training program for national plant protection specialists and farmers. From January 2005 to September 2005, he was recruited as Consultant at IITA in IPM program on vegetable crops in Benin for investigating on the broad mite, Polyphagotarsonemus latus (Banks) and its associated natural enemies on major vegetable crops in Benin.

In September 2005 he was admitted to Georg-August University of Goettingen through a selection as one of the best candidates by the International PhD-Program for Agricultural Sciences in Goettingen and granted a $\mathrm{PhD}$ fellowship by the Deutscher Akademischer Austansch Dienst (DAAD), Germany Governmental scholarship for graduate studies. He 
started then, his PhD-Project at the University of Goettingen, Department of Crop Sciences, Division of Plant Pathology and Plant Protection with Prof. Dr. Andreas von Tiedemann. In 2007 he obtained a field work grant support from the International Fund for Agricultural Development (IFAD) through the International Institute of Tropical Agriculture (IITA) to collect data for molecular investigations. The Final Product in your hand is the fruit of his effort and devotion. 


\section{Certification}

I here by certificated that the work described in this academic thesis have been authentically conducted by me. All co-authors involved have been mentioned in this thesis.

Göttingen, 16 March 2009

Bonaventure Vidjannagni Agboton 